AUTARQUIA ASSOCIADA À UNIVERSIDADE DE SÃO PAULO

\title{
SIMULAÇÃO DO TRANSPORTE DE MANGAS IRRADIADAS PARA EXPORTAÇÃO
}

Aplicações das Técnicas Nucleares

001-Aplicação da radiação ionizante em alimentos e produtos agrícolas.

\section{PAULA OLHÊ BROISLER}

Dissertação apresentada como parte dos requisitos para obtenção do Grau de Mestre em Ciências na Área de

Tecnologia Nuclear - Aplicações

Orientadora:

Dra. Susy Frey Sabato 
INSTITUTO DE PERQUISAS ENERGÉTICAS E NUCLEARES

Autarquia associada à Universidade de São Paulo

SIMULAÇÃO DO TRANSPORTE DE MANGAS IRRADIADAS PARA EXPORTAÇÃO

PAULA OLHÊ BROISLER

Dissertação apresentada como parte dos requisitos para obtenção do Grau de Mestre em Ciências na Área de Tecnologia Nuclear - Aplicações

Orientadora:

Dra. Susy Frey Sabato 


\section{AGRADECIMENTOS}

A minha orientadora querida Dra. Susy Frey Sabato pelo incentivo, pelos ensinamentos, pela compreensão e confiança no meu trabalho.

Ao Dr. Paulo Rela, a Dra. Maria Helena Sampaio e ao Dr. Wilson Calvo pela colaboração e auxílios prestados.

Aos colaboradores da empresa Fruit Fort pela viabilização do meu trabalho.

A Juliana Nunes, parceira de trabalho, pela enorme ajuda e apoio.

Ao Prof. Jorge Berhens pela compreensão, ensinamentos e ajuda.

A todos colaboradores do IPEN.

Aos meus pais pelo enorme apoio e amor.

Ao meu marido Henri pelo eterno apoio, confiança, paciência e por acreditar sempre no meu trabalho. 


\section{SIMULAÇÃO DO TRANSPORTE DE MANGAS IRRADIADAS PARA EXPORTAÇÃO}

\section{Paula Olhê Broisler}

\section{RESUMO}

Neste trabalho foram estudados os efeitos da radiação ionizante (gama) em mangas para exportação, simulando a etapa de acondicionamento da fruta durante o seu transporte, através da refrigeração em câmara fria. Em uma primeira etapa foram analisadas perda de peso, $\mathrm{pH}$, acidez titulável, teor de sólidos solúveis, textura e decomposição. Posteriormente, realizaram-se análises sensoriais (alterações de cor, odor, sabor, textura). Os ensaios foram realizados em dois estádios de maturação das frutas, ou seja, 2 e 3, com o propósito de se estudar o melhor ponto de colheita para a melhor dosagem de irradiação. Os resultados revelam que o tratamento da manga Tommy Atkins na dose de 0,75 kGy foi significativo, juntamente com a fruta no estádio 2, para o retardo do amadurecimento e consequente ganho de tempo para a exportação. 


\title{
TRANSPORT SIMULATION OF MAGOES IRRADIATED FOR EXPORTATION
}

\author{
Paula Olhê Broisler
}

\begin{abstract}
It had been studied the effect of the ionizing radiation (gamma) in mangoes for exportation, simulating the stage of preservation of the fruit during its transport, through the refrigeration in cold chamber. In a first stage they had been analyzed through loss of weight, $\mathrm{pH}$, treatable acidity, soluble solid, texture and decomposition. Later, sensorial analyses had been become fulfilled (alterations of color, odor, flavor, texture). The assays had been carried through in two stadiums of maturation of the fruits, that is, 2 and 3 , with the intention of studying optimum point of harvest for the best dosage of irradiation. The results disclose together that the treatment of the mangoes Tommy Atkins in the dose of 0,75 kGy was significant, with the fruit in stadium 2 , for the retardation of the matureness and consequent profit of time for the exportation.
\end{abstract}




\section{ÍNDICE}

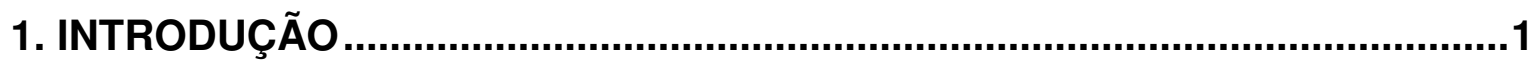

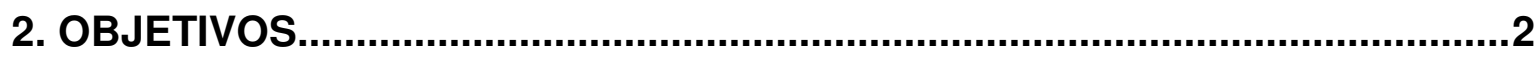

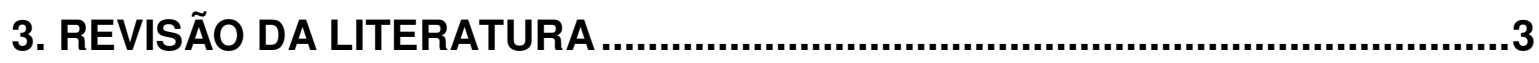

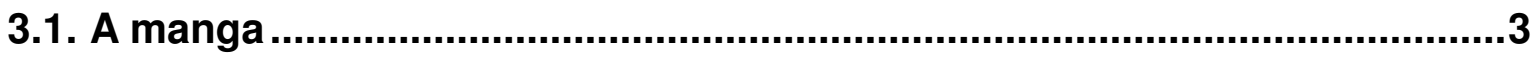

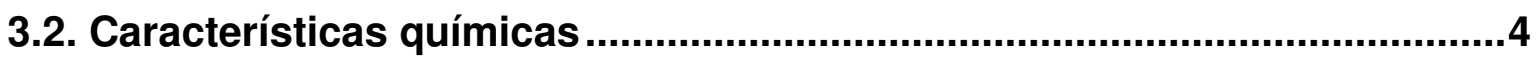

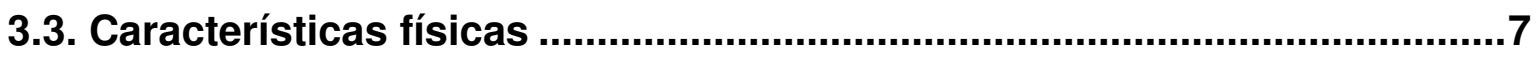

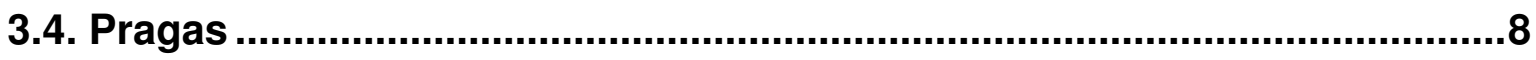

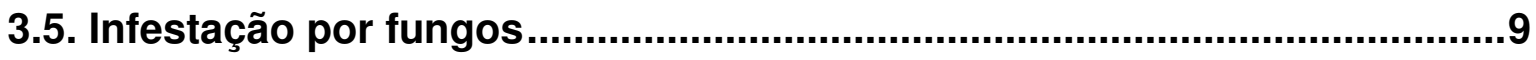

3.6. Desordem fisiológica e nutricional................................................................9

3.7. Produção de mangas ...............................................................................13

3.8. Transporte e acondicionamento das frutas.............................................17

3.9. Importância do Ponto de Colheita ................................................................17

3.10. Fatores internos de conservação pós-colheita .......................................18

3.11. Respiração pós-colheita...........................................................................19

3.11.1. Padrões de atividade respiratória..........................................................19

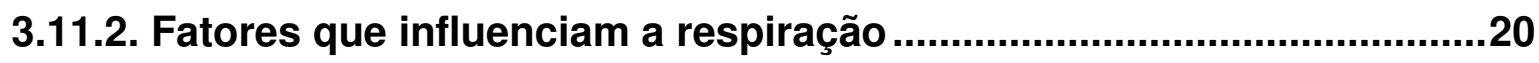

3.11.4. Técnicas pós-colheita para reduzir a respiração ..................................23

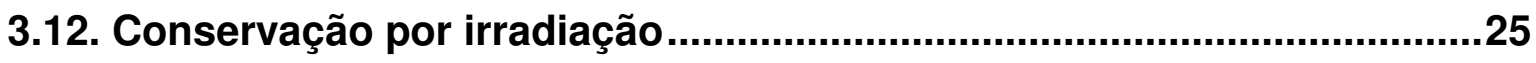

3.13. Efeitos da Radiação sobre Microorganismos.......................................27

3.14. Efeitos da Radiação em Frutas ................................................................29

3.15. Tratamento quarentenário.................................................................30

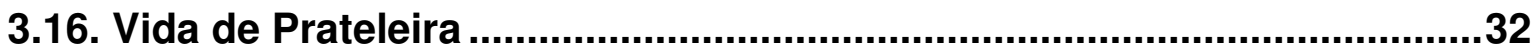

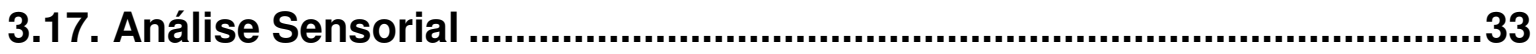

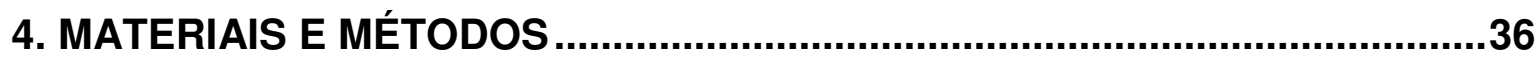

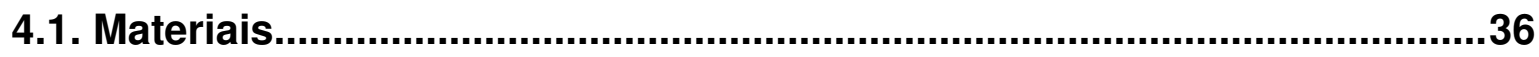

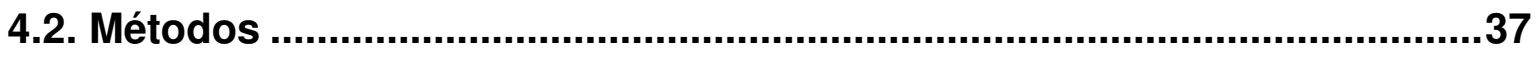




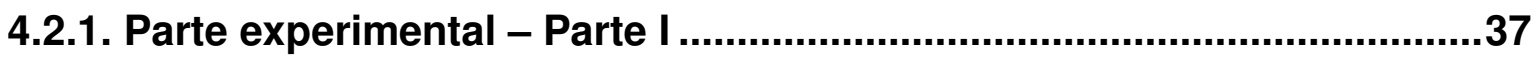

4.2.1.1. Fluxograma da parte experimental - Parte I.......................................42

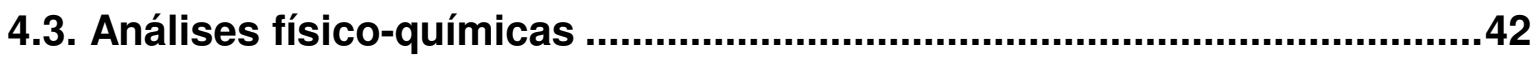

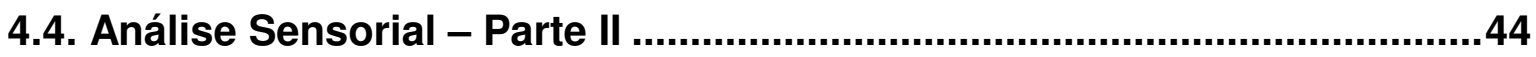

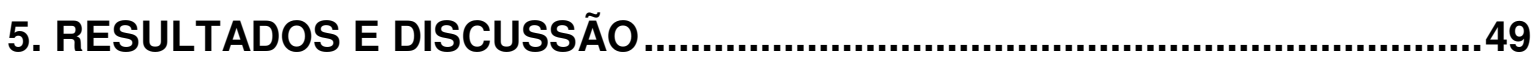

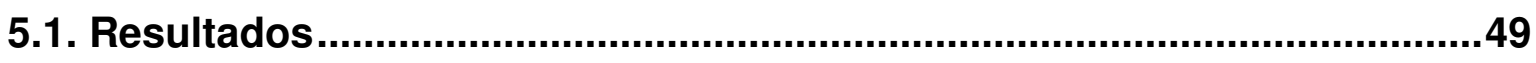

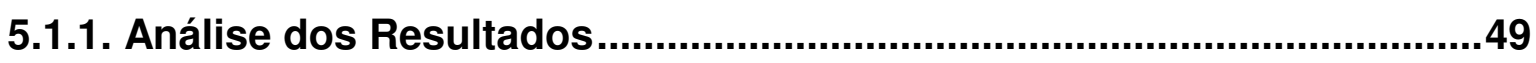

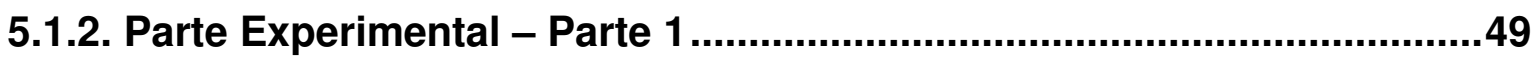

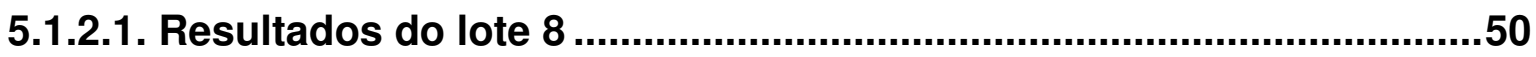

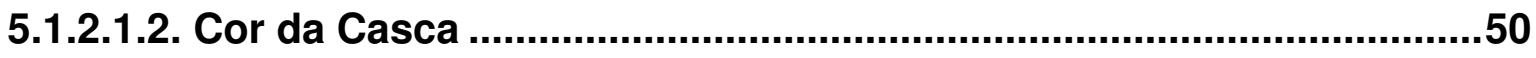

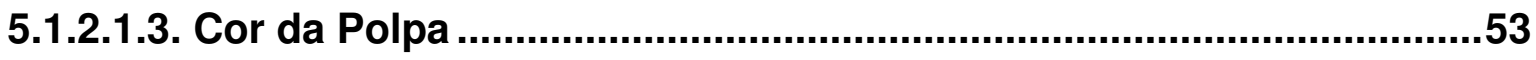

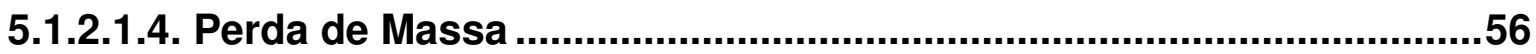

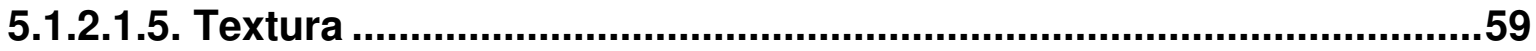

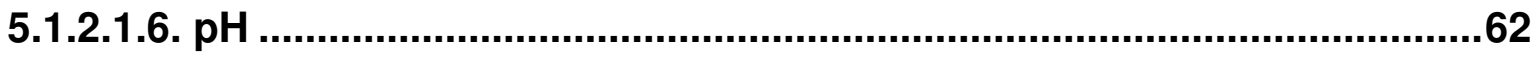

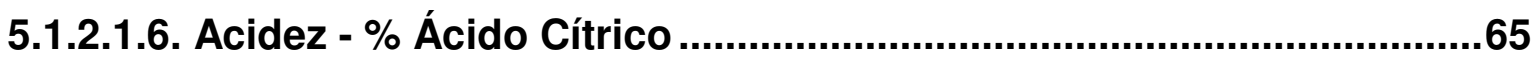

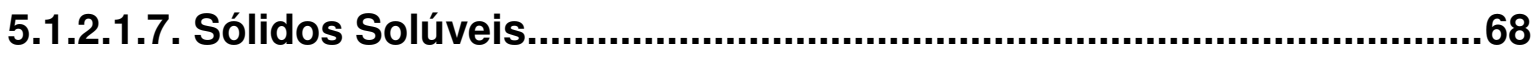

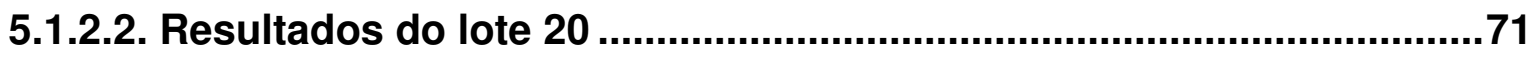

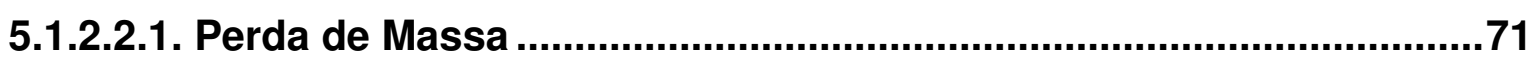

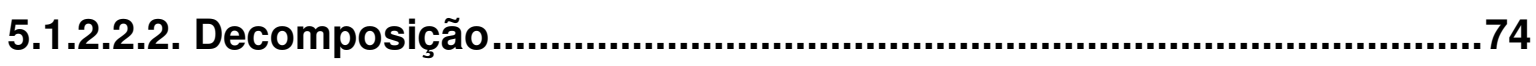

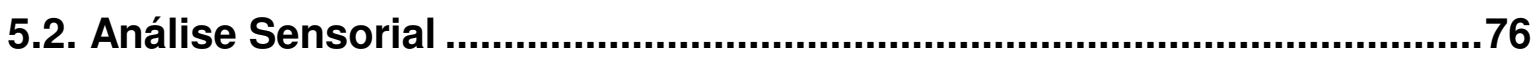

5.2.1. Perfil dos Provadores .........................................................................76

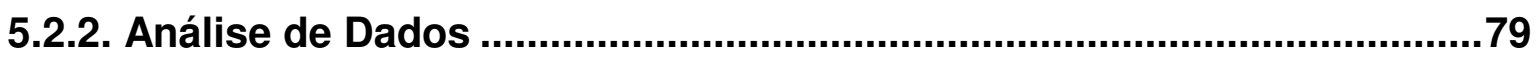

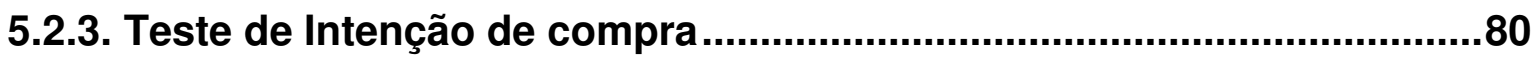

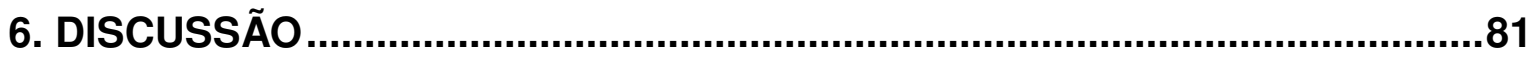

7. CONCLUSÕES

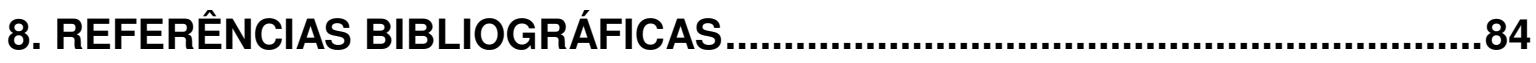




\section{Introdução}

A manga (Mangifera indica L.) é uma fruta tropical de grande importância econômica, sendo o segundo fruto tropical mais importante cultivado no mundo. Entretanto, é uma fruta altamente perecível, e sua distribuição para centros distantes é limitada pela curta vida pós-colheita à temperatura ambiente (YUEN et al., 1993). Por conseguir produzi-la em um período de pouca oferta, a manga é uma das frutas tropicais brasileiras que alcança melhor preço no mercado internacional. Porém, essa situação pode ser modificada, já que outros países também buscam ampliar seus períodos de produção. Para superar este aspecto e estimular o consumo de manga nos países industrializados, o Brasil precisa tomar medidas que assegurem a qualidade elevada, uniforme e constante da fruta que chega ao consumidor (MORAIS et al., 2002).

A fruta apresenta excelente sabor, aroma e coloração característicos. É um fruto de grande aceitação mercadológica, além de ser rico em vitamina C. (BRUNINI et al., 2002)

O tratamento de frutas e vegetais com radiações ionizantes tem como principal finalidade assegurar sua preservação, isto é, aumentar o tempo de conservação do alimento. Este processo pode envolver a inativação de microrganismos (principalmente fungos, bactérias e leveduras), o retardo da maturação, a desinfestação, dentre outros mecanismos. (IEMMA et al., 1999)

Um dos benefícios da irradiação em frutas tropicais é a extensão da vida de prateleira, retardando o processo de maturação e senescência. Mangas pertencem à classe climatérica de frutas, as quais exibem após a colheita, uma evolução na taxa de dióxido de carbono e no consumo de oxigênio que lentamente decai a um mínimo chamado de mínimo pré-climatérico, logo antes do início do estágio de maturação. (THOMAS, 1986)

Este trabalho se insere num projeto de escopo maior onde o objetivo é o estudo de viabilidade da implantação de um irradiador multipropósito na região do Vale do São Francisco. 


\section{Objetivos}

O objetivo da pesquisa foi estudar os efeitos da radiação ionizante (gama) em mangas para exportação, simulando a etapa de acondicionamento da fruta durante o seu transporte, através da refrigeração em câmara fria. Em uma primeira etapa foram analisadas perda de peso, $\mathrm{pH}$, acidez titulável, teor de sólidos solúveis, textura e decomposição. Posteriormente, realizaram-se análises sensoriais (alterações de cor, odor, sabor, textura). 


\section{Revisão da literatura}

\subsection{A manga}

A manga (Mangifera indica L.) pertence à família Anacardiaceae e figura entre as frutas tropicais de maior expressão econômica nos mercados brasileiro e internacional. É uma fruta polposa, de aroma e cor muito agradáveis, e faz parte das frutas tropicais de maior importância econômica não só pela aparência exótica, mas também por ser uma rica fonte de carotenóides, minerais e carboidratos (BRANDÃO et al., 2003).

Entre os principais cultivares de mangas, destacam-se: a Bourbon, Carabao, Rubi, Rosa, Tommy Atkins, entre outras. (LYNCH, 1954)

$O$ fruto maduro serve de alimento, de fortificante e é considerado um diurético. A manga é uma fonte de caroteno, um precursor natural de vitamina A, que são pigmentos carotenóides de cor amarela, os quais se desenvolvem durante $o$ amadurecimento e atingem o seu máximo valor quando os frutos estão maduros. A quantidade de Pró-vitamina A para 100 gramas de polpa comestível pode variar de 770 a 12.340 unidades internacionais, o que the garante o título de fruta campeã mundial como fonte desta vitamina. O Ácido Ascórbico (Vitamina C) varia de 32 a $200 \mathrm{mg}$ para $100 \mathrm{~g}$ de polpa comestível, sendo a manga considerada como fonte de Vitamina $C$ de boa à excelente qualidade. (AKINYELE, \& KESHINRO, 1980)

A manga (Mangifera indica L.) é uma fruta climatérica e se caracteriza por um crescimento rápido das células, com elevada atividade respiratória e com grande capacidade de acúmulo de reservas nutricionais na forma de amido.

O desenvolvimento do fruto da manga, da fertilização até sua plena maturidade, está dividido em 4 estádios distintos, conforme mostra a Figura 1: (MANICA et al., 2001).

1.Juvenilidade: rápida divisão e intenso crescimento celular, elevada taxa respiratória e alta porcentagem de água;

2.Amadurecimento ou Adolescência: taxa de crescimento exponencial, aumento dos compostos aromáticos, grande incremento das taxas respiratórias; 
3.Maturação ou Climatério: ocorre o máximo da atividade respiratória, ascensão do pico climatérico, alcanço da plena maturidade;

4.Senescência: período pós-climatérico, redução da taxa de respiração, redução da acidez, aumento de açúcares.

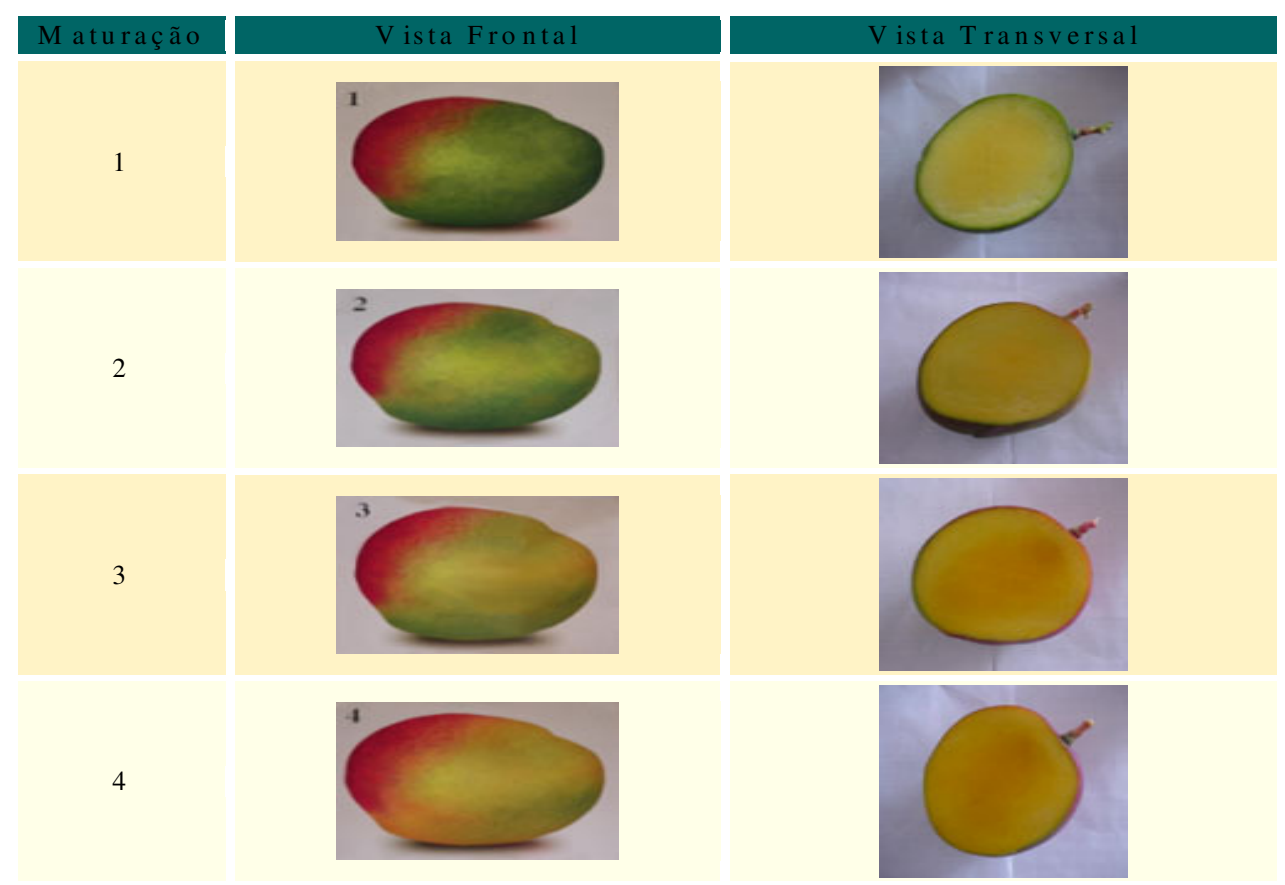

Figura 1 - Estádios de Maturação da Manga

\subsection{Características químicas}

As mangas mais cultivadas no mundo são consideradas frutas de primeira qualidade, são de excelente coloração externa, com polpa sucosa, saborosa, aromática, doce e de textura firme, muito apreciadas pelos consumidores. Os açúcares redutores variam de $3,32 \%$ a $4,20 \%$, os açúcares totais de 10,89 a $14,50 \%$, os sólidos solúveis totais ( ${ }^{0} \mathrm{Brix}$ ) de 16,50 a $21,30 \%$, as fibras de 0,83 a $1,64 \%$, a pectina de 0,96 a $2,00 \%$, um pH de 3,69 a 5,5, com a acidez total de 0,21 a $0,58 \%$ e uma relação ${ }^{\circ}$ Brix/acidez de 38,3 a 158,0. ( $(\mathrm{LNCH}, 1954)$

A manga é constituída principalmente de água, carboidratos, ácidos orgânicos, sais minerais, proteínas, vitaminas e pigmentos (Tabela 1), e possui um valor energético de $58 \mathrm{cal} / 100 \mathrm{~g}$. 
Tabela 1 - Tabela Nutricional da Manga

\begin{tabular}{l|c|l|c}
\hline \multicolumn{4}{c}{ TABELA NUTRICIONAL - MANGA } \\
\hline \multicolumn{4}{c}{ Para 100 g de polpa } \\
\hline \multicolumn{4}{c}{ Valor Energético (Kcal): 64 a 73 } \\
\hline Água (g) & 91,7 & Ferro (mg) & 0,39 a 0,78 \\
\hline Proteínas (g) & 0,40 a 0,70 & Sódio (mg) & 7,0 a 23,1 \\
\hline Lipídios (g) & 0,30 a 0,40 & Potássio (mg) & 76,2 a 189,3 \\
\hline Carboidratos (g) & 16,8 & Magnésio (mg) & 18 \\
\hline Fibras (g) & 0,62 a 1,64 & Vitamina A (U.I.) & 18,160 a 4800 \\
\hline Pectina (g) & 0,96 a 3,06 & Vitamina C (mg) & 32 a 200 \\
\hline Cinzas (g) & 0,4 & Tiamina (mg) & 0,010 a 0,051 \\
\hline Cálcio (mg) & 10 a 34 & Riboflavina (mg) & 0,023 a 0,061 \\
\hline Fósforo (mg) & 17 a 54 & Niacina (mg) & 0,20 a 1,10 \\
\hline
\end{tabular}

Fonte: MANICA et. al., 2001.

No fruto, encontra-se $48,7 \%$ a $89,3 \%$ de polpa, com 5,2 a $24,45 \%$ de casca, de 5,4 a $19,72 \%$ de caroços. Foi determinado que o teor de umidade no fruto é mais ou menos constante, mas, que os sólidos solúveis totais, a acidez titulável, os teores de vitamina $\mathrm{C}$ e de pigmentos carotenóides de mangas maduras variam consideravelmente entre os diferentes cultivares, e o comportamento metabólico de cada cultivar pode modificar-se, o que altera a longevidade da pós-colheita dos frutos. (MANICA et al., 2001)

A água encontra-se em maior proporção nas frutas verdes, mas à medida que amadurecem, tende a se reduzir, devido a sua transpiração em proporção não muito elevada, de acordo com a cultivar. Os carboidratos, que também se acham em elevadas proporções na composição da manga, são formados por amido, açúcares, celulose, pectina e tanino. Enquanto o fruto permanece na planta, o acúmulo de amido é a principal atividade nos tecidos da polpa, cujo teor aumenta intensamente, chegando a $13 \%$ quando há o seu completo desenvolvimento, mas, após a colheita do fruto, este amido é totalmente hidrolisado em oito dias. À medida que a fruta vai crescendo, aumenta proporcionalmente $\mathrm{o}$ teor de amido, mas, quando ela completa $\mathrm{o}$ seu desenvolvimento fisiológico, se inicia a sua redução, com a transformação em açúcares. Os açúcares constituem a maior quantidade de sólidos solúveis totais na manga madura. (SILVA et al., 2003) 
De acordo com o Ministério da Agricultura ${ }^{1}$ (2000), polpa ou purê de manga é o produto não fermentado e não diluído, obtido da parte comestível da manga, através de processo tecnológico adequado, com teor mínimo de sólidos totais. A polpa deverá obedecer aos Padrões de Identidade e Qualidade fixados para polpa de fruta e seguir as características e composição abaixo (Tabela 2):

-Cor: amarelo;

-Sabor: doce, levemente ácido;

-Aroma: próprio.

Tabela 2 - Características da polpa da manga

\begin{tabular}{l|c|c}
\hline & Mínimo & Máximo \\
\hline Sólidos solúveis em ${ }^{\circ}$ Brix, a $20^{\circ \mathrm{C}}$ & 11,00 & - \\
\hline $\mathrm{pH}$ & 3,3 & 4,5 \\
\hline Acidez total expressa em ácido cítrico $(\mathrm{g} / 100 \mathrm{~g})$ & 0,32 & - \\
\hline Açúcares totais naturais da manga $(\mathrm{g} / 100 \mathrm{~g})$ & - & 17,00 \\
\hline Sólidos totais $(\mathrm{g} / 100 \mathrm{~g})$ & 14,00 & - \\
\hline
\end{tabular}

Fonte: Ministério da Agricultura, 2000.

As mangas verdes, fisiologicamente desenvolvidas, contêm os seguintes ácidos: málico e cítrico em maior quantidade e os demais, oxálico, succínico, oxalacético, alfa-oxiglutárico e pirúvico. A acidez aumenta no sentido da casca para o caroço. A acidez total da fruta, que é normalmente expressa em ácido cítrico ou málico, demonstra que as frutas possuem uma acidez que varia de $0,17 \%$ a $3,66 \%$ nos frutos verdes e de 0,11 a $0,56 \%$ em frutos maduros. (MANICA et al., 2001)

Dentro dos fatores de qualidade das frutas um dos mais importantes é o sabor, dado pelo balanço entre os açúcares solúveis e ácidos orgânicos. Durante o amadurecimento da manga, o conteúdo de ácidos orgânicos diminui e o de açúcares solúveis aumenta, resultando num predomínio do sabor doce na fruta madura.

\footnotetext{
${ }^{1}$ http://oc4j.agricultura.gov.br/agrolegis
} 
Estudos revelam que a glicose, a frutose e a sacarose são os únicos açúcares solúveis encontrados durante as fases de desenvolvimento e de amadurecimento da manga. Os teores de sacarose são sempre menores do que $1 \%$, permanecendo inalterados após a colheita, enquanto que os teores de frutose aumentam constantemente durante todo o período de maturação da fruta. A frutose é a hexose predominante na manga madura, variando de 2,3 a 3,1\%, enquanto que a glicose varia de 0,05\% a 0,6\%. Uma possibilidade é que este desequilíbrio seja resultado de uma utilização preferencial da glicose pela via respiratória, por exemplo, resultado "na sobra" de frutose no tecido. (SILVA et al., 2003)

Lacroix (1993) avaliou o efeito da irradiação ionizante sobre as vitaminas A e C. Concluiu que sobre o ácido ascórbico nas doses de até 1KGy não contribuem para alterações na degradabilidade da vitamina em relação à amostra não tratada. Entretanto, resultados significativos foram verificados para a vitamina A. Em comparação com uma amostra de manga controle, observou-se que a manga tratada por irradiação apresentou uma redução da vitamina $A$ menor do que a não tratada, concluindo-se que a irradiação a baixas dosagens não afeta a concentração de vitamina A na manga.

\subsection{Características físicas}

Com relação ao aspecto físico, inicialmente, a manga apresenta a espádua em linha com o ponto de inserção do pedúnculo, e a coloração da casca é verde oliva. Na medida em que a espádua vai-se elevando em relação a o ponto de inserção do pedúnculo, ou seja, para as extremidades, a casca inicia a mudança de cor verde para ligeiramente amarelada, o que indica o ponto de colheita da manga. (BLEINROTH, 1994)

As principais características físicas da mangas são:

- Coloração da casca: a sua tonalidade verde oliva passa a verde-clara brilhante, e posteriormente, aparece coloração entre amarela ou vermelha arroxeada, dependendo da cultivar; 
- Textura: a polpa da manga vai perdendo a sua consistência à medida que a fruta amadurece. Utilizando-se um penetrômetro, que contêm uma haste e na sua extremidade uma agulha (punção), a qual é introduzida na fruta, através da compressão que se exerce sobre ela, pode-se medir a textura do fruto. Para efetuar-se esta operação, é necessário, primeiramente, retirar a casca em pequenas áreas e em três ou quatro locais distintos na região equatorial da fruta. Para cinco cultivares no México, as normas estabelecem valores que variam de 11,0 a 15,6 Kgf de firmeza; já para as mangas exportadas pelo Brasil, os valores estão entre 8,5 a 11,4 Kgf, utilizando um penetrômetro com haste de 5/8 de polegada. (BLEINROTH, 1994)

\subsection{Pragas}

Das pragas que afetam a cultura da manga, destacam-se insetos e ácaros, que atacam as folhas, ramos, troncos, flores e frutos da mangueira. Algumas pragas (ácaro, broca da mangueira, lagarta, moscas-das-frutas, etc.) são de ocorrência generalizada e podem causar grandes perdas; outras aparecem esporadicamente, ou são consideradas importantes por estarem ligadas à transmissão de doenças (Antracnose, Oídio, etc.).

Sabe-se que somente os frutos de alta qualidade, livres de doenças, distúrbios fisiológicos e pragas podem conquistar novos mercados. Existem, entretanto, exigências específicas da parte dos países importadores de frutas frescas, que devem necessariamente devem necessariamente ser atendidas. Em primeiro lugar, são feitas rigorosas restrições à entrada de frutas portadoras de organismos exóticos, que possam representar riscos para a agricultura do país importador. (BUSTOS et al., 2004)

O mercado interno também está a cada dia, mais exigente quanto à qualidade dos frutos. Dessa forma, frutos com manchas na casca, coloração anormal e/ou com amolecimento interno da polpa já estariam fora do mercado. Mesmo a indústria a exigência aparece quanto à qualidade interna e externa da manga, pois os frutos com cascas manchadas por doenças fúngicas ou bacterianas e/ou com amolecimento ou colapso interno da polpa encarecem o 
processo de industrialização por exigirem uma pré-limpeza e seleção, além de alterações nas características físico-químicas. (MANICA et al., 2001)

Sternochetus mangiferae é uma praga responsável pela redução da germinação do caroço, ocasionando danos na polpa e orifícios na manga prematura (Follet, 2001).

\subsection{Infestação por fungos}

Durante o armazenamento, os problemas patológicos mais sérios na manga são causados pelos fungos Colletotrichum gleosporioides e Botryodiplodia theobromas. Em frutos verdes, os fungos podem permanecer em estado latente, até que se estabeleçam condições propícias para o seu desenvolvimento, o que ocorre com o seu amadurecimento (Silva et al.,2006).

O controle de doenças pós-colheita em manga é realizado com o uso de fungicidas, além de cuidados no manejo de campo e manuseio pós-colheita. No entanto, existem limitações para o uso desses produtos nos pomares de manga orientadas para o mercado externo, mesmo quando associadas ao banho térmico (Malavasi, 1989).

Silva et al.(2006) concluiu que o tratamento da manga por irradiação inibe o desenvolvimento de lesões fúngicas, $B$. theobromae e $C$. gloeosporioides nos frutos. As dosagens 0,5 e 0,75kGy apresentaram melhor controle dos fungos nas duas temperaturas estudadas, $12^{\circ} \mathrm{C}$ e $25^{\circ} \mathrm{C}$.

\subsection{Desordem fisiológica e nutricional}

Com relação à nutrição e aos atributos físicos e tecnológicos da fruta existe pouca experimentação. Entre os aspectos físicos da manga, a cor da casca mostra-se muito importante. Durante o amadurecimento dos frutos, ocorrem várias alterações bioquímicas, sendo a clorofila degradada, havendo acúmulo de antocianina (pigmento vermelho) que se acumula ao mesmo tempo em que os carotenóides aumentam. Existem várias razões que causam alterações na cor da manga, como as manchas esverdeadas. Conforme Mckenzie (1994) o fator 
nutricional da planta e do fruto constituem os mais importantes fatores para explicar a coloração da casca da manga.

Pomares de mangueira que recebem altas doses de nitrogênio têm maior freqüência de frutos verdes, comparados com pomares com baixa adubação em nitrogênio, que têm maior freqüência de frutos amarelos. (ROZANE, et. al., 2004)

A adubação nitrogenada apesar de aumentar a produção da mangueira eleva também, a incidência de colapso interno dos frutos, principalmente em solos ácidos, com pouco cálcio. Esta é uma das principais razões da dificuldade que se tem para manejar corretamente a adubação nitrogenada na cultura da manga. (TEIXEIRA, et al., 2001)

McKenzie (1995), avaliando diferentes cultivares de mangueira (Sensations; Kent; Tommy Atkins, Heidi e Keitt) na África do Sul, verificou a necessidade do uso moderado da adubação nitrogenada a partir de níveis que considerem o valor mais baixo da faixa de insuficiência do nutriente para o melhor desenvolvimento da cor da casca, à exceção a cultivar Heidi, em que níveis mais elevados são aceitáveis. No Brasil, pomares de mangueira com teor de $\mathrm{N}$ foliar > $12 \mathrm{~g} / \mathrm{kg}$ tendem a ter maior incidência de frutos com coloração verde.

Young \& Miner (1961) verificaram que diferentes combinações de doses de $\mathrm{N}, \mathrm{P}, \mathrm{K}$, e Mg foram aplicadas em dois tipos de solos (ácido e calcário) da Flórida, cultivados com manga da variedade Kent, para se observar os efeitos destes tratamentos na incidência de colapso interno ("soft-nose"). No solo ácido, o aumento na dose de $\mathrm{N}$ de 0,35 a 2,4 kg por planta, aumentou a porcentagem de frutos com colapso interno de 10 para 76\%, independente das doses de $\mathrm{P}$ e $\mathrm{K}$. Por outro lado, no solo originado de calcário, aumentos até maiores de nitrogênio, não provocaram aumentos da incidência de "soft-nose". É importante observar as variações na concentração de cálcio e da relação N/Ca nas folhas da mangueira, para os dois solos. Com base nos resultados de Young \& Miner (1961) concluíram que a incidência de "soft-nose" aumenta quando a relação de N/Ca nas folhas da manga é superior a 0,5 .

Wainwright e Burbage (1989) definem desordem fisiológica como o resultado de um desequilíbrio no metabolismo induzido por um ou mais fatores ambientais na pré ou pós-colheita, levando ao colapso celular e ao aparecimento de áreas escuras e aquosas em alguma parte da polpa. Sua ocorrência ainda não é totalmente esclarecida. A aplicação de zinco nos frutos da mangueira em pré- 
colheita melhora a sua qualidade, devido ao aumento do conteúdo de açúcares e sólidos solúveis totais.

No Brasil, este problema tem se agravado nos últimos anos, especialmente em mangueiras melhoradas de origem americana, a exemplo a Tommy Atkins, Van Dyke e Zill. Assim, uma das prováveis causas dessas desordens é o desequilíbrio nutricional, que pode estar condicionado pelo patrimônio genético da cultivar, uma vez que, nas mesmas condições de ambiente e tratos culturais, as variedades diferem entre si quanto à suscetibilidade à desordem. Mangas fibrosas como Espada e Coquinho são pouco ou quase nada afetadas, ao passo que as cultivares melhoradas como Tommy Atkins é mais susceptível. (ROZANE, et. al., 2004)

O colapso interno dos frutos da manga é um distúrbio fisiológico, cuja ocorrência é generalizada pelo mundo e conhecido na literatura internacional, de uma forma genérica de "internal fruit breakdown". Entretanto, existem algumas variações tais como: "soft-nose", "jelly-seed", "internal fruit necrosis", "spongy tissue", "black tip" que são as mais freqüentes. (TEIXEIRA, et al., 2001)

Os sintomas aparecem nos estágios iniciais de maturação do fruto na planta, ou no fruto já colhido:

- Ocorre a separação entre a semente e os feixes vasculares (que se ligam ao ramo), havendo abertura entre o endocarpo e a junção do pedúnculo;

- Perda de firmeza da polpa, que degenera sua consistência. Este amolecimento localiza em volta do endocarpo (região mais intensa da polpa) e avança por toda polpa;

A polpa muda de cor, de branco-esverdeado para amarelo, e depois para laranja. No exterior da fruta, há o desenvolvimento de uma cor mais clara em certas áreas da casca; em estágios mais avançados, essas áreas tornam-se moles, enquanto os tecidos adjacentes ainda estão firmes. (TEIXEIRA, et al., 2001)

Pinto et. al. (1994) em suas pesquisas, concluíram que o gesso é um excelente fonte de cálcio para a mangueira. Entretanto, as condições climáticas são determinantes para a absorção desse nutriente, facilmente observável através da relação $\mathrm{N} / \mathrm{Ca}$ nas folhas. Isto explica as variações entre anos na incidência de amolecimento da polpa dos frutos. Nota-se ainda que doses mais 
elevadas de $\mathrm{N}$ agrava o problema com a qualidade dos frutos, mesmo com a aplicação de gesso.

O Boro também é um nutriente cuja deficiência tem causado distúrbios fisiológicos em frutos. Na índia, Ram et. al. (1989) associaram outra anomalia de frutos de manga com a deficiência de boro, denominando-a de "internal fruit necrosis" (IFN), cujos sintomas são semelhantes ao "soft-nose". Estes sintomas iniciam pela coloração verde escura na parte apical do fruto, que evolui para coloração parda escura. Internamente os tecidos da polpa dessa região, desintegram numa massa marrom escura, com exsudação da goma. A variedade Dashehari parece ser a mais sujeita ao problema. Pelos resultados de Ram et. al. (1989), os teores foliares de B precisam ser superiores a 70 ppm (coleta de folhas segundo Young \& Koo, 1972), e nos frutos superiores a 20 ppm, para se evitar "internal fruit necrosis".

Silva \& Menezes (2001) avaliaram a qualidade pós-colheita da manga Tommy Atkins, colhida no estádio de maturação e submetida à aplicação précolheita de $\mathrm{CaCl}_{2}$ (1\% e 2\%) e números de aplicações (2,3 e 4 vezes). Do total de 280 frutos colhidos, 175 foram levados para análise imediata, enquanto que 105 permaneceram em câmara fria $\left(10^{\circ} \mathrm{C}\right)$ por 30 dias. Porém, as concentrações de $\mathrm{CaCl}_{2}$ testadas não resultaram em incremento do teor de cálcio no fruto e também não influenciaram as características de qualidade avaliadas. Houve efeito do número de aplicações de $\mathrm{CaCl}_{2}$ sobre a textura, sólidos solúveis (após 30 dias) e de açúcares solúveis totais (após colheita). Concluíram que a incidência de colapso interno não foi associada à aplicação de cálcio, mas afirmam que as concentrações utilizadas, provavelmente, foram insuficientes para que houvesse manifestação do efeito de cálcio, podendo ainda esse fato ser atribuído à metodologia de aplicação, não sendo satisfatória a absorção do produto pelos frutos, considerando que o cálcio é um nutriente de pouca mobilidade nos tecidos vegetais. 


\subsection{Produção de mangas}

Praticamente, em todos os estados do Brasil existe produção de manga. No entanto, essa cultura está mais concentrada em alguns estados, como São Paulo, Minas Gerais, Bahia e Pernambuco.

O Brasil está entre os nove principais países produtores de manga do mundo com uma área de 67 mil hectares e produziu em 2001 um total de 540 mil toneladas dessa fruta. Desse total, exportamos 94 mil toneladas o que representou $17,4 \%$ de nossa produção, resultando em divisas da ordem de 51 milhões de dólares na pauta de exportação brasileira. Os $82,6 \%$ restantes da produção ficaram para a comercialização e consumo no mercado interno brasileiro. A região Nordeste é a principal região produtora de manga do país com $53 \%$ da produção nacional, sendo o Vale do São Francisco o eldorado brasileiro da produção e exportação de manga. (PINTO, 2002)

Segundo a Companhia de Desenvolvimento do Vale do São Francisco Codevasf $^{2}$ (2005), o Vale do São Francisco é a região de maior destaque da produção de mangas. Nesse território (Figura 2) há uma área de 81.000 há com fruticultura, sendo 74.000 já irrigados, onde são cultivadas 40 espécies frutícolas e 191 variedades.

O Submédio São Francisco, uma das regiões do Vale do São Francisco, que se situa entre os Estados da Bahia e Pernambuco e apresenta uma hidrologia apoiada no rio São Francisco. O clima predominante é o semi-árido tropical e a temperatura média é de $27^{\circ} \mathrm{C}$, a uma umidade relativa de $50 \%$.

\footnotetext{
${ }^{2}$ http://www.codevasf.gov.br/menu/os vales/imagens/mapa1
} 
É nessa região que se encontra o principal pólo frutícola do Nordeste brasileiro, que é o Pólo de

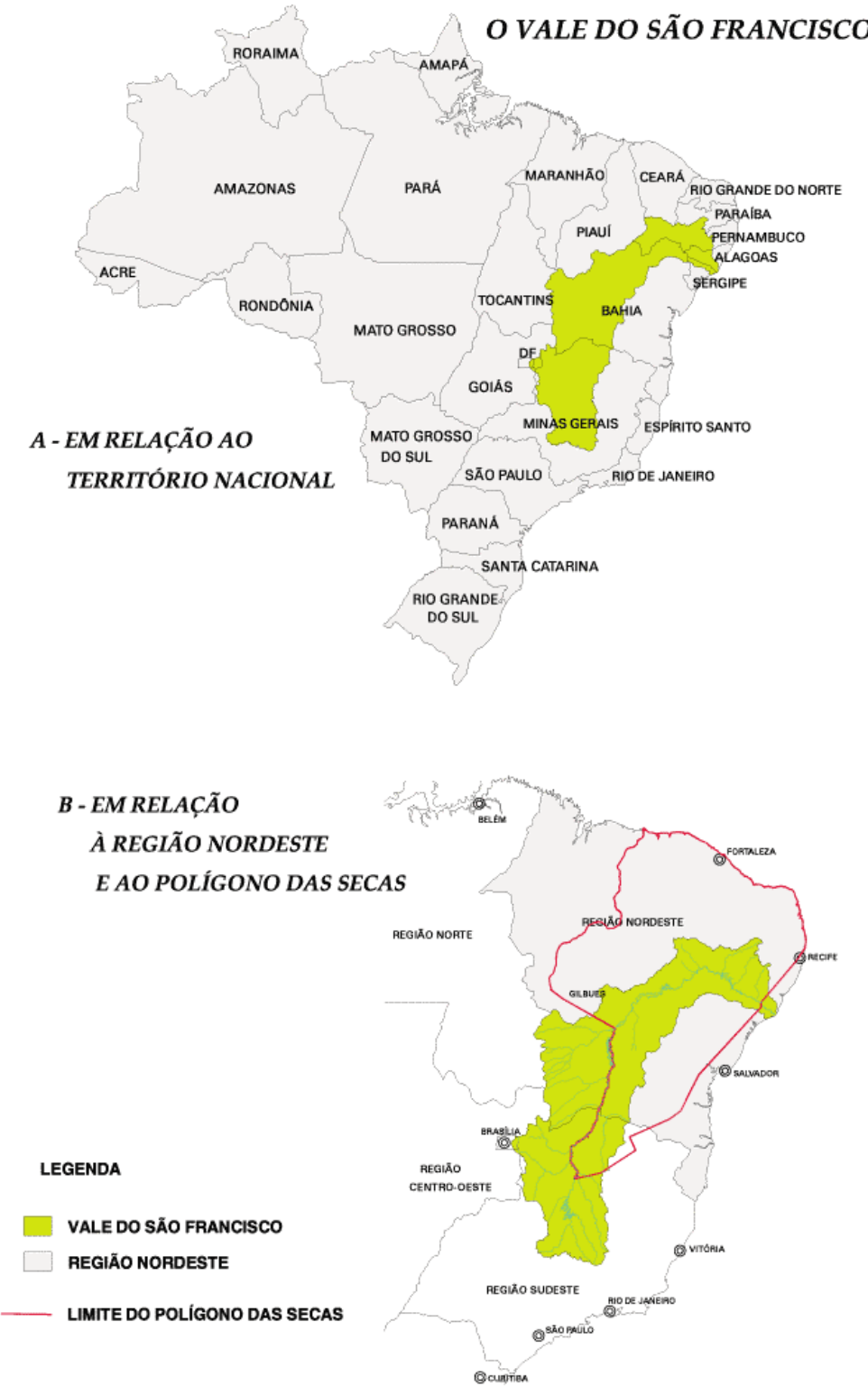
Petrolina (PE)/Juazeiro(BA).

Em termos de infraestrutura para essa atividade, principalmente para exportação, a Valexport (Associação de produtores da região do Vale do São Francisco) estima que haja na região $97.500 \mathrm{~m}^{2}$ de packing houses (unidades de beneficiamento) instalados, o que representa um investimento total de US $\$ 34,5$ milhôes. São 46 packing houses cadastrados na Valexport, 21 com instalações frigoríficas, apresentando capacidade média de beneficiamento de $100 \mathrm{t} / \mathrm{dia}$ para manga. (ALVES \& BURNQUIST, 2002)

Figura 2 - Região Brasileira Produtora de Mangas

Das exportações brasileiras de manga (para Estados Unidos e Europa) em 2003, 93\% foram do Vale do São Francisco. O mesmo porcentual se aplica ao total em dólares: dos US $\$ 75,74$ milhões, a manga nordestina contribuiu com US $\$$ 68,2 milhões. De acordo com a Valexport, a exportação de mangas da região tende a crescer, em 2005, com o início da comercialização da fruta com o Japão. (LACERDA, 2005)

Cabe ressaltar que o Brasil, após 32 anos de negociação, fechou acordo com o governo japonês para exportar manga Tommy Atkins, produzida no Vale do 
São Francisco, que deve somar 5,2mil toneladas por ano. Os carregamentos da fruta destinados ao Japão deverão passar por tratamento hidrotérmico (lavagem com água quente) para evitar a presença de larvas e ovos da mosca do mediterrâneo, além do tratamento para matar bactérias. Esse tratamento será acompanhado por um inspetor japonês, custeado pelos exportadores brasileiros (O Estado de São Paulo, 2004).

De acordo com a $\mathrm{FAO}^{3}$ (2005), o Brasil apresenta uma produção de mangas crescente a cada ano (Tabela 4), porém o México ainda é o maior produtor e exportador das frutas (Tabela 3 ), mundialmente.

Tabela 3 - Países exportadores de mangas

\begin{tabular}{c|c|c|c|c}
\hline Mangas & \multicolumn{4}{|c}{ Ano } \\
$\begin{array}{c}\text { Exportação - } \\
\text { Val (1000\$) }\end{array}$ & $\mathbf{2 0 0 0}$ & $\mathbf{2 0 0 1}$ & $\mathbf{2 0 0 2}$ & $\mathbf{2 0 0 3}$ \\
\hline México & 111,126 & 122,922 & 99,834 & 117,200 \\
\hline Brasil & 35,764 & 50,814 & 50,849 & 75,744 \\
\hline China & 1,334 & 1,681 & 2,161 & 3,695 \\
\hline Malásia & 1,384 & 2,438 & 1,903 & 1,418 \\
\hline França & 10,507 & 16,586 & 12,950 & 17,245 \\
\hline
\end{tabular}

Fonte: $\mathrm{FAO}, 2005$.

Tabela 4 - Produção mundial de mangas

\begin{tabular}{c|c|c|c|c|c}
\hline Produção de & \multicolumn{5}{|c}{ Ano } \\
\cline { 2 - 6 } Mangas (Mt) & $\mathbf{2 0 0 0}$ & $\mathbf{2 0 0 1}$ & $\mathbf{2 0 0 2}$ & $\mathbf{2 0 0 3}$ & $\mathbf{2 0 0 4}$ \\
\hline Brasil & 538,301 & 782,308 & 842,349 & 845,000 & 845,000 \\
\hline China & $3.210,692$ & $3.272,875$ & $3,513,366$ & $3,420,513$ & $3,622,000$ \\
\hline Malásia & 19,568 & 19,572 & 19,570 & 19,570 & 19,570 \\
\hline México & $1,559,351$ & $1,577,450$ & $1,523,160$ & $1,503,010$ & $1,503,010$ \\
\hline Estados Unidos & 3,000 & 3,000 & 2,300 & 2,600 & 2,800 \\
\hline
\end{tabular}

Fonte: FAO, 2005

\footnotetext{
${ }^{3}$ http://faostat.fao.org/faostat/collections?subset=agriculture
} 
Os corredores de exportação de manga na região de Petrolina (PE) /Juazeiro (BA), representados pelos portos de Salvador (BA), Natal (RN), Mucuripe (CE) e Suape (PE), estão apresentados no fluxograma (Figura 3) da cadeia produtiva de manga, que é composta de cinco elos: i. sistema de produção (fazenda), ii. transporte até a unidade de beneficiamento (packing houses), iii. unidade de beneficiamento, iv. Principais corredores (rodovias) de exportação e v. principais portos a que leva cada um dos corredores. (ALVES \& BURNQUIST, 2002)

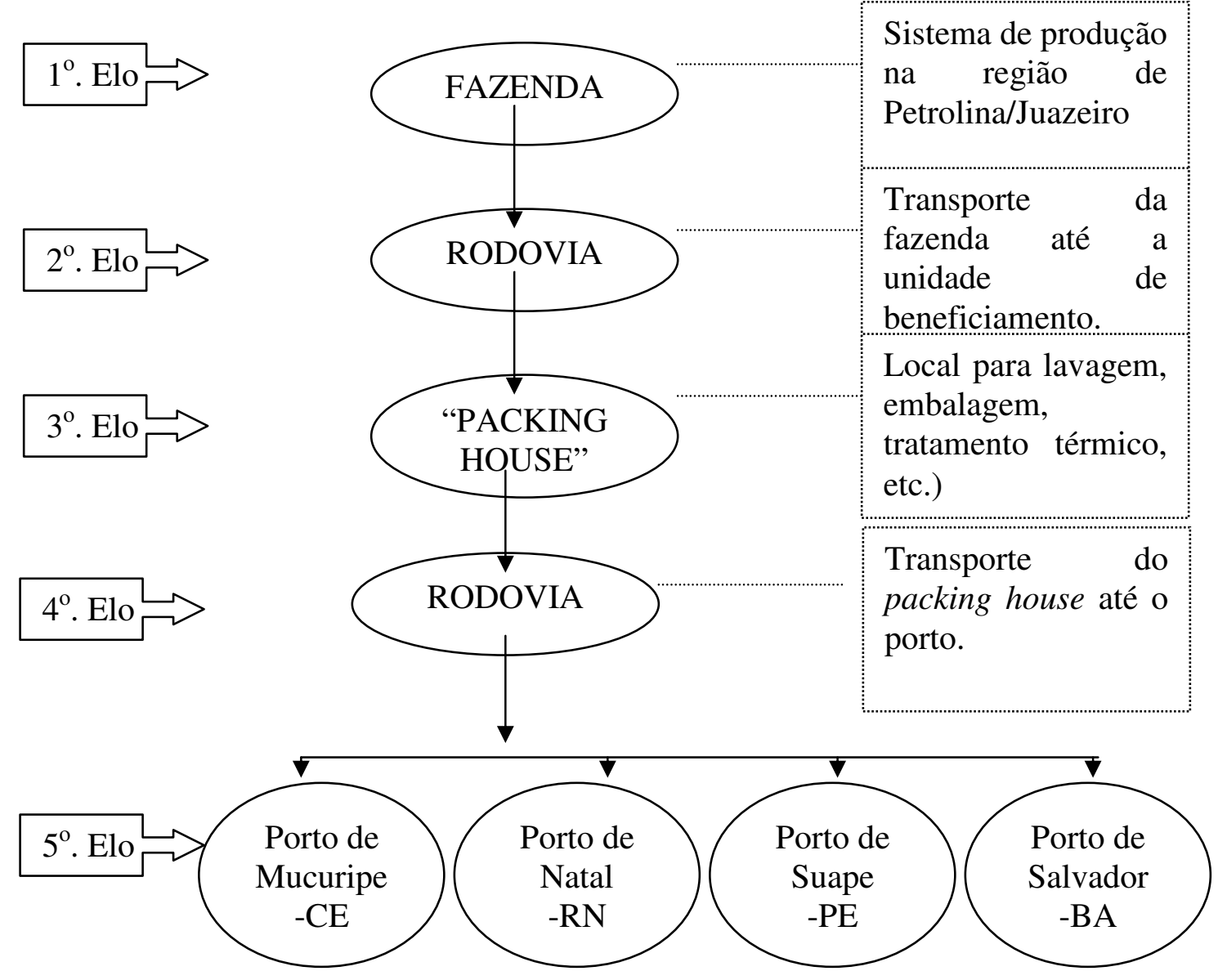

Figura 3 - Fluxograma da cadeia produtiva de manga e os principais produtores de exportação. 


\subsection{Transporte e acondicionamento das frutas}

O tipo de embalagem em que a fruta é acondicionada tem influência na vida de prateleira da fruta e dos produtos derivados de manga, pois por apresentarem teores de vitamina $\mathrm{C}$, exigem um material que ofereça boa proteção contra oxidação e luz, e, também, contra a perda de umidade e contaminação microbiana. (BRUNINI et al., 2002)

Os materiais de acondicionamento mais indicados para o transporte das mangas são caixas de papelão ondulado que conferem maior proteção e reduzem ocorrências de injúrias, danos mecânicos (LACERDA, A., 2005).

Considerando a necessidade de regulamentar 0 acondicionamento, manuseio e comercialização dos produtos hortícolas "in natura" em embalagens próprias para comercialização, visando à proteção, conservação e integridade dos mesmos, o Ministério da Agricultura ${ }^{4}$ (2002) determinou que as embalagens, sendo estas descartáveis ou retornáveis, devem ser íntegras e higienizadas e estarem de acordo com as disposições específicas referentes às Boas Práticas de Fabricação, ao uso apropriado e as normas higiênico-sanitárias relativas a alimentos.

\subsection{Importância do Ponto de Colheita}

A qualidade da manga para consumo e sua capacidade de conservação pós-colheita dependem, principalmente, do grau de estádio de desenvolvimento do fruto no momento da colheita. Assim, frutas que não completaram a fase de desenvolvimento fisiológico no campo podem conservar-se por um longo período de tempo, porém jamais alcançarão à qualidade ideal para consumo. (GUARINONI A., 2000)

Morais et al. (2002) caracterizaram e determinaram o melhor estádio de maturação para a colheita de mangas 'Tommy Atkins' destinadas ao mercado Europeu. As avaliações foram feitas por ocasião da colheita e após 21 dias de armazenamento refrigerado ( $13 \pm 1{ }^{\circ} \mathrm{C}$ e $99 \%$ UR). Observou-se que, os picos climatéricos ocorreram aos 10 dias após a colheita nos frutos colhidos no estádio

\footnotetext{
${ }^{4}$ http://agricultura.org.br
} 
2 e aos 7 dias nos colhidos nos estádios 3 e no de colheita comercial (EC). Os frutos colhidos nos estádios 2, 3, 4 e EC (definido pelo produtor) amadureceram normalmente após 21 dias de armazenamento refrigerado. Sendo que os colhidos nos estádios 3 e EC se apresentaram muito semelhantes e alcançaram melhor qualidade.

Filgueiras et al. (2000) relataram que atualmente se recomenda como ponto de colheita para manga destinada a Europa e Canadá, um ponto de colheita com cor da polpa correspondente a nota entre 2 e 3 na escala. Portanto, os frutos nos estádios avaliados obtiveram notas compatíveis com as exigências do mercado para cor da polpa, com exceção das mangas colhidas no estádio 4, que já apresentavam cor mais acentuada, com nota superior a 4,0 e muito avançadas no que concerne a sua maturidade. Todavia, tem-se observado que esses indicadores de maturação variam com a região de produção, pois mangas colhidas na região de Petrolina - PE apresentam diferença na coloração da polpa em relação à das mangas produzidas na região de Mossoró-Assu (RN), e no Estado do Piauí, tornando-se assim, necessário o estabelecimento de uma escala própria para cada região de cultivo.

\subsection{Fatores internos de conservação pós-colheita}

O principal fator de influência, intrínseco da planta, fruta e hortaliça é a respiração. Além da espécie do produto e do tipo de tecido (jovem ou velho), existem outros fatores capazes de influenciar a intensidade de respiração de uma fruta ou hortaliça. Assim, produtos com maior conteúdo de água em sua composição respiram mais e se conservam por mais tempo.

A produção de etileno, um hormônio de maturação e envelhecimento de vegetais, ocorre naturalmente durante a fase de amadurecimento dos furtos, principalmente dos climatéricos. O gás etileno também é utilizado pelo homem quando se deseja estimular o amadurecimento de frutos como a banana, a manga, entre outros.

Outro processo natural que se pode observar em produtos de todas as idades é a transpiração. Frutas e hortaliças possuem de 85 a 95\% de água em seus tecidos e aproximadamente $100 \%$ em seus espaços intermoleculares. Como 
no meio ambiente a umidade relativa atinge o valor de cerca de $80 \%$, a água passa da maior concentração nas plantas para a menor concentração no meio ambiente. Isso se dá através da transpiração, a qual, quando em excesso pode modificar a aparência dos produtos tornando-os enrugados e opacos. Nesse caso, a textura apresenta-se mole, flácida e murcha, e o peso pode diminuir em até $10 \%$ do peso inicial. Quanto maior a superfície exposta do produto, maior é a sua taxa de respiração. (WILLS, et al., 1982)

Segundo Bender \& Brecht (2000), a armazenagem de mangas dos cultivares Kent e Tommy Atkins em atmosferas de $\mathrm{CO}_{2}$ superiores a 25\%, por 14 ou 21 dias, resulta em incrementos na atividade respiratória e no metabolismo anaeróbico que podem causar prejuízos à qualidade dos frutos. Concomitantemente ao aumento do metabolismo anaeróbico em atmosferas com elevado $\mathrm{CO}_{2}$ ocorre a redução da produção de etileno, e após transferência para ar, não ocorre tomada da biossíntese de etileno nos níveis observados em mangas apenas armazenadas em ar. A redução da concentração de $\mathrm{O}_{2} \mathrm{da}$ atmosfera ambiente para $3 \%$, na presença de elevado $\mathrm{CO}_{2}$ tem pouco efeito nas produções de etanol e etileno.

\subsection{Respiração pós-colheita}

\subsubsection{Padrões de atividade respiratória}

De acordo com o tipo de respiração que os frutos apresentam, estes podem ser classificados em dois grupos distintos, ou seja, os não climatéricos e os climatéricos.

São considerados frutos não climatéricos os que apresentam um contínuo declínio na taxa de respiração em função do tempo. Dentre eles, tem-se: limão, laranja, abacaxi, morango (BIALE, 1960).

Frutos não climatéricos somente amadurecem enquanto estiverem ligados à planta. Após a colheita, eles não melhoram suas qualidades de excelência e nutricional, embora um leve amolecimento e perda de coloração verde possam ocorrer (MEDLICOTTI, 1986).

Neste caso não existe nenhuma relação entre a respiração e as mudanças que se manifestam com a maturação dos frutos (ARAGÓN et al., 1984). 
Segundo Awad (1990), frutos climatéricos têm um aumento rápido e significativo da taxa respiratória durante a maturação.

As etapas desse aumento são: pré-climatérico, mínimo pré-climatérico, aumento climatérico, pico climatérico e pós-climatérico. Dentre os frutos climatéricos podemos citar: pêra, abacate, banana, tomate.

\subsubsection{Fatores que influenciam a respiração}

a)Tipo de produto

Cada espécie possui sua taxa respiratória própria. E, mesmo dentro da mesma espécie a atividade respiratória pode variar entre as cultivares de determinado produto.

De acordo com Biles et al (1993) a taxa respiratória de pimenta cultivar Chiltepin e cultivar Tabasco foram maiores do que as cultivares Chooraehong e New Mexican.

b) Relação superfície/volume

Quanto maior for a relação superfície/volume, maior será a respiração do vegetal. Assim, se comparar a taxa respiratória de uma alface comum com a de uma alface de cabeça, constata-se que a primeira apresentará uma maior evolução de $\mathrm{CO}_{2}$. Isto porque tem uma maior superfície de exposição às trocas gasosas (CHITARRA, 1990).

c) Temperatura

A intensidade respiratória de frutos e hortaliças após a colheita está intimamente relacionada à temperatura. Ela pode interferir diretamente na velocidade da reação dos processos metabólicos, no tempo de armazenamento, bem como causar distúrbios fisiológicos (chilling).

A atividade respiratória é reduzida pelo uso de baixa temperatura. Em frutos climatéricos, o abaixamento da temperatura retarda o pico climatérico e 
reduz sua intensidade podendo o mesmo ser totalmente suprimido na faixa de temperatura próxima ao limite fisiológico de tolerância do fruto (CHITARRA, 1990).

De acordo com Amorim (1985), entre temperaturas de 5 a $25^{\circ} \mathrm{C}$ o quociente de temperatura $\left(Q_{10}\right)$ se situa entre 2,0 e 2,5.

A temperatura influencia a velocidade de uma reação biológica. De acordo com a Lei de Vant'Hoff, a cada $10^{\circ} \mathrm{C}$ na variação da temperatura a velocidade das reações metabólicas aumenta em 2 a 3 vezes, dentro da faixa fisiológica de temperatura.

Hardenburg (1971) constatou que a taxa respiratória de pêssegos embalados com polietileno, foi reduzida com a diminuição da temperatura. Verificou-se que a taxa respiratória foi reduzida de $72 \mathrm{mg}$ para $5 \mathrm{mg} \mathrm{CO} 2 \cdot \mathrm{kg}^{-1} \cdot \mathrm{h}^{-1}$ ao abaixar-se a temperatura de 21 para $0^{\circ} \mathrm{C}$, respectivamente.

d) Concentração de oxigênio

Uma vez que o oxigênio do ar é o componente mais importante para que se realize a respiração aeróbica, deve estar disponível em quantidade adequada. Se restringido o acesso do oxigênio aos frutos, ocorrerá a fermentação, que é acompanhada da produção de odores e sabores desagradáveis (MITCHELL et al., 1972)

A fermentação pode ser evitada, armazenando-se os frutos em contentores bem ventilados.

A ventilação adequada (disponibilidade de oxigênio) está diretamente relacionada ao:

- tipo de embalagem e contentores utilizados para transportar ou armazenar o produto;

- quantidades de ceras artificiais aplicadas às frutas.

Entretanto, a redução na concentração de oxigênio é uma técnica muito útil para controlar a taxa de respiração das frutas. Este é o princípio utilizado no armazenamento em atmosfera controlada ou modificada (PANTASTICO, 1975) e no armazenamento hipobárico (ou baixa pressão) dos produtos perecíveis (CRUCEFIX, 1986). 
O consumo de oxigênio pela fruta pode ser utilizado para se determinar sua taxa de respiração. O resultado é expresso em $\mathrm{ml} \mathrm{O}_{2} \cdot \mathrm{Kg}^{-1} \cdot \mathrm{h}^{-1}$ ou $\mu \mathrm{O}_{2} \cdot \mathrm{g}^{-1} \cdot \mathrm{h}^{-1}$.

Geralmente a concentração de oxigênio deve ser reduzida a menos de $10 \%$ para obtenção de efeito positivo na redução da respiração. No entanto, são necessários cuidados para que não se atinja níveis de oxigênio que promovam a respiração anaeróbica, associada ao desenvolvimento de aroma e sabores desagradáveis e à quebra de componentes estruturais dos tecidos, o que provoca perda de firmeza do produto. Além disso, o nível mínimo de oxigênio em que certo produto pode ser armazenado sem problemas não é constante, mas dependente da temperatura e da resistência da epiderme à difusão do oxigênio (DADZIE et al., 1993).

e) Concentração de gás carbônico

De acordo com Chitarra (1990), a adição de $\mathrm{CO}_{2}$ ao ar ou ao $\mathrm{O}_{2}$ em concentrações superiores à do ar, prolonga o processo de maturação tanto em frutos climatéricos como em não climatéricos, sendo o efeito uma função da concentração de $\mathrm{CO}_{2}$. Níveis de 5 a $10 \%$ de $\mathrm{CO}_{2}$ diminuem a atividade respiratória e retardam o início do climatério. Níveis muito elevados de $\mathrm{CO}_{2}$ causam injúrias aos tecidos. Bender et al (1994) observaram que concentrações de $50 \%$ e $70 \%$ de $\mathrm{CO}_{2}$ aumentaram a taxa de produção de etanol em mangas armazenadas a $12^{\circ} \mathrm{C}$.

f) Acúmulo de etileno

O etileno é considerado um hormônio de amadurecimento de frutos e é fisiologicamente ativo em quantidades iguais a 0,1 ppm (ABELES, 1973).

Reduzindo $\mathrm{O}_{2}$ a níveis menores que $8 \%$ a produção de etileno é reduzida em frutas e hortaliças. $\mathrm{O}_{2}$ é necessário para a síntese e ação do etileno, uma vez que sob condições anaeróbicas a conversão do ACC (ácido 1aminociclopropanocarboxílico) a etileno é inibida, promovendo um acúmulo de ACC no tecido, uma vez que a passagem de metionina a ACC ocorre mesmo na Ausência de $\mathrm{O}_{2}$. Altas concentrações de $\mathrm{CO}_{2}$, por sua vez, podem reduzir, promover ou não ter nenhum efeito na taxa de produção de etileno pelo fruto, 
dependendo do produto e da concentração a que este é exposto. Em alguns frutos, ocorre um acúmulo de $\mathrm{CO}_{2}$ nos espaços intercelulares e este funciona como um antagonista natural do etileno (KADER, 1992).

g) Injúrias mecânicas

Todo e qualquer tipo de lesão mecânica às frutas e hortaliças pode causar um estímulo na atividade respiratória. De modo geral, frutos climatéricos são mais susceptíveis à influência deste fator, pois a estimulação da respiração devido às lesões físicas provavelmente está relacionada ao efeito indireto do etileno. Isto porque os tecidos vegetais em deterioração produzem mais etileno que os sadios.

A ocorrência de danos mecânicos nos tecidos minimamente processados é inevitável, uma vez que o produto é descascado e/ou picado. De acordo com Moretti (1999), frutos de pimentão minimamente processados armazenados à $2^{\circ} \mathrm{C}$ apresentaram elevação significativa da atividade respiratória logo após o processamento, sendo três vezes maior do que os frutos intactos armazenados sob a mesma condição.

\subsubsection{Técnicas pós-colheita para reduzir a respiração}

a) Redução da temperatura

- Pré-resfriamento

Tem por finalidade a remoção rápida do calor de campo dos produtos recém-colhidos, antes do transporte, armazenado ou processamento. Quando realizado de modo adequado restringe as atividades enzimáticas e respiratórias, entre outros benefícios (CHITARRA, 1990).

\section{- Refrigeração}

A refrigeração é o método mais econômico para o armazenamento prolongado de frutos e hortaliças frescos (CHITARRA, 1990).

O abaixamento da temperatura diminui a velocidade do metabolismo respiratório. Os frutos que apresentam uma taxa respiratória baixa apresentam de maneira geral, melhor conservação nas baixas temperaturas. Os frutos de origem 
tropical possuem taxas respiratórias altas, toleram menos temperaturas muito baixas e podem ser conservados apenas durante pouco tempo (AWAD, 1990).

b) Alteração na composição atmosférica

\section{- Atmosfera modificada}

A atmosfera modificada, juntamente com o uso da refrigeração, pode atrasar o amadurecimento dos frutos, estendendo, assim, sua vida pós-colheita (COELHO, 1994).

De acordo com este autor, o processo de respiração do produto armazenado em embalagens de polietileno consome oxigênio e causa acúmulo de gás carbônico e água, o que reduz o metabolismo, a síntese e a ação do etileno, e consequentemente, evita a perda de água pela transpiração (perda de peso) e o enrugamento.

Oliveira et al (1996) observaram que frutos de goiaba tratados com película de fécula de mandioca 1 e $2 \%$ apresentaram menores valores de taxa respiratória em relação ao tratamento testemunha.

\section{Atmosfera controlada}

O processo de atmosfera controlada implica na adição ou remoção de gases, resultando em uma composição gasosa diferente da atmosfera normal do ar (KADER, 1980).

Kim (1976) observou que tomates inicialmente armazenados em atmosferas contendo $2,5 \%$ ou $15 \%$ de $\mathrm{O}_{2}$ produziam taxas baixas de $\mathrm{CO}_{2} \mathrm{e}$ etileno e, consequentemente, a maturação foi retardada. A seguir, expondo os frutos a uma atmosfera normal (ar), o desenvolvimento da maturação foi normalizado.

c) Reguladores vegetais

As auxinas, giberelinas e citocininas, têm sido estudadas com interesse particular por funcionarem total ou parcialmente como retardadores da senescência de frutos. 
A aplicação de giberelina em banana retarda o amadurecimento, com manutenção do teor de clorofila na casca, firmeza do fruto e baixa taxa respiratória (CHITARRA, 1990).

Golding (1999) verificaram que a aplicação de 1-MCP ( Metilciclopropeno) em bananas retardou o início do pico do etileno e reduziu a taxa respiratória, atrasando o amadurecimento.

d) Colheita no estádio ideal

Frutos climatéricos devem ser colhidos durante o estágio mínimo climatérico, onde sua taxa respiratória é baixa. Caso sejam colhidos na fase climatérica (alta taxa respiratória) poderá apresentar uma rápida taxa de deterioração antes da comercialização (CHITARRA, 1990)

e) Mínimo manuseio do produto

O manuseio excessivo e inadequado de produtos hortícolas pode ocasionar injúrias no tecido vegetal, aumentando a taxa respiratória.

\subsection{Conservação por irradiação}

A radiação pode ser definida como sendo a emissão e propagação da energia ou partículas através do espaço ou matéria e irradiação é o processo de aplicação de energia radiante a um alvo qualquer, no caso, um determinado alimento. (FRANCO \& LANDGRAF, 1996)

$\mathrm{Na}$ irradiação de alimentos uma forma particular de irradiação é utilizada, conhecida por radiação ionizante. Dos diversos tipos de radiação ionizante apenas duas são utilizadas em irradiação de alimentos: radiação eletromagnética, principalmente a gama e raios-X e a radiação por feixe de elétrons. A radiação eletromagnética é uma energia em forma de ondas enquanto que radiação pela emissão de elétrons é corpuscular e se dá pela aceleração da velocidade dos elétrons e durante este movimento transmite energia. (ICGFI; Vienna, 1992) 
Segundo a Agência Nacional de Vigilância Sanitária, a Anvisa ${ }^{5}$, fontes de radiação são aquelas autorizadas pela Comissão Nacional de Energia Nuclear, na conformidade das normas pertinentes, a saber:

-Isótopos radioativos emissores de radiação gama: Cobalto 60 e Césio - 137;

-Raios $\mathrm{X}$ gerados por máquinas que trabalham com energias de até $5 \mathrm{MeV}$;

-Elétrons gerados por máquinas que trabalham com energias de até $10 \mathrm{MeV}$.

A excitação e ionização que ocorrem em alimentos, envolvem apenas os elétrons externos dos átomos, aqueles menos ligados ao núcleo e que são responsáveis por fazer as ligações entre os átomos formando os compostos químicos. Como resultado, os efeitos de tal excitação e ionização são limitados a mudanças químicas, não havendo riscos de induzir a radioatividade no alimento. (ICGFI; Vienna, 1992).

O emprego da radiação ionizante na conservação de alimentos foi patenteado nos Estados Unidos em 1929. No entanto, só nos últimos 30-40 anos é que os cientistas de muitos países começaram realmente a dar maior atenção a esse método. (FRANCO \& LANDGRAF, 1996)

Uma vez que a irradiação pode promover vários efeitos benéficos, tratamentos específicos são requeridos para assegurar os efeitos desejados. Para se utilizar a irradiação efetivamente é necessário saber quais os tipos de efeitos são desejáveis para um determinado alimento numa situação em particular.

Enquanto os efeitos benéficos da irradiação são buscados, é necessário que se reconheça que a irradiação em alguns casos pode, como em qualquer outro processo alimentício de conservação, prejudicar a qualidade do alimento. (CAMARGO, R. J. 2004)

A radiação pode reduzir perdas na pós-colheita ao matar insetos em frutas, grãos ou ervas, reduzindo danos alimentares causados por estes organismos, inibindo a germinação de vegetais e postergando o amadurecimento de frutas. (DEL MASTRO, 1996)

O tipo de mudança ocorrido no material, que está absorvendo a radiação, está relacionado com a energia contida nos elétrons. A intensidade da mudança obtida está relacionada com a quantidade de radiação absorvida. A quantidade de energia absorvida é, em parte, função do poder da fonte radioativa, o tempo

\footnotetext{
${ }^{5}$ http://www.anvisa.gov.br/legis/resol/21 $01 \mathrm{rdc} . \mathrm{htm}$
} 
total de exposição à radiação, e da relação entre a fonte de radiação e as características de absorção do material irradiado. A quantidade de energia absorvida é chamada de dose. A unidade no Sistema Internacional de Unidades é gray (Gy) e equivale a $1 \mathrm{~J} / \mathrm{kg}$ de alimento. (ICGFI; Vienna, 1992)

A Anvisa determina que as doses de irradiação devem obedecer ao seguinte critério:

- Qualquer alimento poderá ser tratado por radiação desde que sejam observadas as seguintes condições:

a) A dose mínima absorvida deve ser suficiente para alcançar a finalidade pretendida;

b) A dose máxima absorvida deve ser inferior àquela que comprometeria as propriedades funcionais e ou os atributos sensoriais do alimento.

Alguns cuidados devem ser tomados com 0 alimento antes de ser submetido à radiação:

- Seleção dos alimentos: estes devem estar em bom estado de frescor e qualidade, devendo ser evitados aqueles com deterioração incipiente;

- Limpeza dos alimentos: qualquer sujidade ou partícula deve ser removida. Esse cuidado diminuirá o número de microorganismos presentes;

- Embalagem: deve proteger o alimento da contaminação pós-processamento.

- Branqueamento ou tratamento térmico: enzimas do alimento não são inativadas pelas doses utilizadas na irradiação de alimentos. Portanto, é necessário destruílas antes do processo, pois caso contrário serão responsáveis pela deterioração posterior do alimento. (FRANCO \& LANDGRAF, 1996)

\subsection{Efeitos da Radiação sobre Microorganismos}

Quando um alimento é irradiado o ácido nucléico DNA das células vivas é ionizado ou excitado como as outras moléculas. Qualquer alteração nesta molécula irá alterar a mensagem que ela carrega, que permite a célula funcionar e se reproduzir. Acima de uma determinada dose as alterações serão numerosas que não será mais possível repará-las, levando a morte das células ou à sua incapacidade de reprodução. (CAMARGO, R. J. 2004) 
Os efeitos da irradiação nos microorganismos podem necessitar de tempo para se manifestar. A seqüência de eventos que segue a irradiação pode ocorrer de diferentes maneiras dependendo da dose. Os efeitos da irradiação estão principalmente relacionados com os danos às reações metabólicas, especialmente no DNA de células vivas. Um importante aspecto das células vivas é sua capacidade de recompor os danos causados pela irradiação. Uma dose alta o suficiente pode prevenir a recomposição das células. (ICGFI; Vienna, 1992)

A eficiência de uma determinada dose de radiação sobre os microorganismos depende dos seguintes fatores:

- Radioresistência do microorganismo: como outros agentes antimicrobianos, a resposta da célula microbiana à radiação ionizante está relacionada à natureza e à quantidade do dano direto produzido em seu alvo vital, ao número, natureza e longevidade dos radicais químicos induzidos pela radiação e à habilidade inerente à célula em tolerar ou reparar o dano e influência dos meios extras e intracelular. Dessa forma, qualquer tentativa em se classificar ou comparar a radioresistência dos microorganismos somente tem significado quando todas as condições forem bem definidas e compreendidas;

- Número de microorganismos: quanto maior o número de microorganismos presente, maior será a dose necessária para a sua destruição;

- Composição do alimento: o meio em que microorganismo se encontra tem influência sobre a radioresistência. Os microorganismos em meios protéicos são mais resistentes do que aqueles que se encontram em solução tampão. As proteínas exercem efeito protetor contra as radiações de maneira análoga ao que ocorre no tratamento térmico;

- Presença ou ausência de oxigênio: a ausência de oxigênio torna o microorganismo mais resistente à radiação. A adição de substâncias redutoras ao meio, por exemplo, compostos com radicais sulfidrilas têm o mesmo efeito, elevando a radioresistência, como um ambiente anaeróbio;

- Estado físico do alimento: células desidratadas são mais resistentes à radiação do que as no estado normal. Este efeito é, provavelmente, conseqüência da radiólise da água pelas radiações ionizantes;

- Condições do microorganismo: os microorganismos tendem a ser mais resistentes à radiação quando na fase lag, imediatamente antes da divisão celular ativa. As células tornam-se mais sensíveis conforme progridem na fase 
logarítmica, atingindo o mínimo de sensibilidade no fim dessa fase. (FRANCO \& LANDGRAF, 1996)

\subsection{Efeitos da Radiação em Frutas}

As frutas devem ser classificadas de acordo com o comportamento respiratório durante sua fase de maturação e com a sua classe, climatérica ou não-climatérica. Frutas climatéricas exibem uma lenta taxa de respiração decrescente que chega ao seu mínimo antes de iniciar a maturação. Com o início da maturação a respiração aumenta intensamente e chega ao seu pico quando a fruta se torna madura. A degradação final da fruta (senescência) é acompanhada por um declínio na taxa de respiração da fruta. Frutas não-climatéricas são normalmente colhidas já maduras e mostram uma lenta taxa de respiração decrescente sem qualquer período de pico de atividade. (CAMARGO, R. J. 2004).

A irradiação de frutas climatéricas no período pré-climatérico produz respostas melhores à irradiação do que frutas irradiadas depois do estágio climatérico. (ICGFI; Vienna,1992).

Uma vez que a resposta de frutas climatéricas à radiação está relacionada com o seu estágio de maturação, o uso da radiação para sua preservação ou outro fim, deve levar isto em consideração para minimizar os efeitos indesejáveis e assegurar os desejáveis.

A radiação pode levar à mudanças na composição química das frutas. Tais mudanças envolvem alterações na quantidade de vitamina, conversão de protopectina à pectina, degradação da celulose e do amido, destruição de alguns ácidos e mudanças na pigmentação. As alterações na textura ocorrem devido às mudanças na pectina e celulose e podem ser um fator limitante na quantidade de radiação empregada na fruta.

Uma baixa dose de irradiação em frutas é realizada para desinfestação de insetos para permitir exportação para países que exigem tratamento que asseguram a segurança microbiológica da fruta e para retardar o amadurecimento das frutas. Para as frutas climatéricas a radiação oferece uma combinação de efeitos, desinfestação somado ao retardamento da maturação. O retardamento da 
senescência é uma das principais razões para a aplicação da irradiação nas frutas. (ICGFI; Vienna,1992)

Testes físico-químicos e sensoriais mostram que a qualidade das mangas irradiadas a uma dosagem de no máximo 1000 Gy também não é modificada. Bustos et al. (1990) observou que o metabolismo da fruta não foi acelerado em razão de não haver aumento significativo registrado nas taxas de respiração e transpiração, e a aceitabilidade da manga irradiada foi semelhante ao fruto "in natura".

O efeito inicial da radiação sobre os tecidos celulares da manga é a destruição da semipermeabilidade da célula com a água, interferindo na textura da fruta. O tecido torna-se progressivamente menos resistente sob altas dosagens de radiação. Porém, sensorialmente, esta alteração não é significativa a dosagens de até 1000 Gy. (GAGNON et al., 1993).

Juntamente com o processo da radiação ionizante, a temperatura de acondicionamento da manga é um fator de importância. Estudos mostram que o tratamento a uma dose de até 1000 Gy e posterior armazenamento da fruta a $15^{\circ} \mathrm{C}$ por quatro semanas não provoca alterações organolépticas e sensoriais significativas, enquanto que sob a uma temperatura de $23^{\circ} \mathrm{C}$ (temperatura ambiente), a manga atinge os estágios de maturação e senescência mais rapidamente. (KARIM et al., 1990).

\subsection{Tratamento quarentenário}

O controle eficiente de insetos e a sua remoção de produtos alimentícios têm sido um desafio há muito tempo de produtores e processadores de alimentos. Apesar da existência de muitos métodos de controle, a indústria de alimentos continua buscando um método mais seguro e mais viável economicamente.

Um grande número de insetos pode ser carregado por frutas e vegetais durante o manuseio na pós-colheita. Muitas dessas espécies de insetos podem causar distúrbios na comercialização destas mercadorias entre os países. Conseqüentemente, um tratamento efetivo de desinfestação de insetos, que não seja prejudicial ao consumidor, ao comerciante e ao produto, é essencial para permitir a distribuição de frutas e vegetais. (CAMARGO, R. J. 2004) 
Para Byrne (1996) o uso da irradiação pode superar barreiras ao satisfazer diferentes regulamentações quarentenárias. Moy e Wong (2002) afirmam que a eficiência da irradiação baseia-se na sua capacidade de controlar todas as larvas e ovos de pestes que possam estar presentes. Para Karder (1986) a possibilidade do uso da radiação ionizante para a desinfestação de insetos é a sua mais promissora aplicação.

Para Tilton e Burditt (1983) a tecnologia da irradiação para a eliminação de pestes parece oferecer soluções desejáveis em muitos aspectos. O tratamento com irradiação leva menos tempo que a fumigação, não deixa resíduos indesejáveis e pode ser tão efetiva quanto qualquer outro método existente em controlar a infestação de insetos. Os autores colocam ainda que o desenvolvimento da resistência a inseticidas pelas espécies de insetos é um problema crescente. Desta forma, a desinfestação pelo uso da radiação tem uma grande vantagem em relação aos produtos químicos utilizados, uma vez que os insetos não se tornaram mais radioresistentes com o uso da irradiação.

Para a desinfestação de moscas-da-fruta, a dose de radiação, segundo Moy (1986), corresponde a três conceitos nos quais não existe completa concordância entre os cientistas:

- Dose suficientemente alta para não resultar no desenvolvimento dos ovos, normalmente entre 0,40 e 0,60 kGy;

- Dose moderada para que os insetos não se desenvolvam normalmente até o estágio adulto, resultando em insignificante risco de peste, normalmente a doses de 0,25 e 0,35 kGy;

- Baixas doses, mínimas de 0,15 kGy, para afetarem os genes dos insetos a ponto de fazer perdê-los a habilidade de se reproduzirem.

Uma dose absorvida de 0,25 kGy foi sugerida por Kader (1986) como um tratamento quarentenário efetivo para frutas e vegetais, uma vez que pára a reprodução de insetos e causa mínimos efeitos na qualidade. Isto, contudo, irá requerer alterações nas regulamentações quarentenárias, a qual estabelece que praticamente todas as espécies vivas de pestes, devem ser mortas para que o tratamento quarentenário seja aceito. O critério de avaliação da efetividade do tratamento quarentenário deve então ser baseado na habilidade de reproduzir, mais do que na mortalidade do inseto, isto porque a dose de irradiação que mata os ovos e larvas e/ou induz a esterilidade de inseto ou outras anormalidades nos 
adultos são efetivas em parar a reprodução. Para Hallman (1999) os fatos de o inseto permanecerem vivo por algum tempo após a irradiação tem sido um dos maiores obstáculos para a utilização da tecnologia.

A irradiação, a doses de 150 Gy a 350 Gy, contribui para o processo de desinfestação da manga, eliminando pragas, como as moscas e larvas, que causam grandes prejuízos a fruta desde sua colheita até o seu consumo. (KARIM et al., 1990).

\subsection{Vida de Prateleira}

Um dos principais objetivos de um tecnologista de alimento é conseguir prever a alteração de qualidade de um produto em particular em função do tempo e das condições ambientais. Isto tem se tornado muito importante, pois de posse dessas informações a indústria de alimentos pode avaliar o efeito de novos ingredientes ou aditivos na vida-de-prateleira de um produto; estampar um prazo de validade na embalagem, de forma que os consumidores fiquem melhores informados sobre como manusear o produto e ainda garantir que o alimento está dentro dos padrões nutricionais declarados no rótulo.

Para que seja possível a realização de previsões válidas de vida-deprateleira são necessárias as seguintes informações sobre:

- Os principais modos potenciais de perda de qualidade do produto;

- Os fatores que controlam a qualidade inicial ou o valor nutricional durante o processo de fabricação;

- As condições ambientais que o alimento ficará exposto, incluindo temperatura, umidade relativa e luminosidade;

- Se o alimento é acondicionado em numa embalagem semipermeável, e se o for, qual a permeabilidade do filme ao oxigênio, vapor d'água e luminosidade;

- A cinética das reações responsáveis pela perda de qualidade ou valor nutricional como função das condições intrínsecas do alimento e do meio externo ao qual está exposto.

Uma vez que os alimentos são sistemas químicos muito complexos, nem sempre é possível identificar claramente os mecanismos das reações químicas que determinam as alterações de qualidade observadas. 
Deve-se, portanto, fixar um parâmetro indicador da deterioração do determinado alimento, chamado de Padrão de Identidade e Qualidade (PIQ) e estabelecer como este será medido. Esta será então a característica crítica do alimento, que pode ser um número máximo de microorganismos, a acidez desejada, a cor, o odor, o sabor e a textura característica do alimento, e que podem ser determinados através de testes microbiológicos, de medidas de $\mathrm{pH}$, de acidez titulável, de textura, de viscosidade ou ainda por análise sensorial.

A vida de prateleira do produto será determinada pela alteração máxima no atributo de qualidade crítico do produto, aceita pelo consumidor, pelo fabricante ou pela legislação.

Assim com dados experimentais dos valores medidos do atributo de qualidade crítica, em intervalos de tempo determinados, sabendo qual o valor crítico de deterioração do seu produto e as condições em que será armazenado, é possível calcular a vida-de-prateleira do produto.

\subsection{Análise Sensorial}

A análise sensorial é definida como uma disciplina cientifica usada para medir, analisar e interpretar reações das características dos alimentos e dos materiais. São muitas as aplicações da análise sensorial na indústria de alimentos e nas instituições de pesquisa, como por exemplo, o controle das etapas de desenvolvimento de um novo produto, a avaliação do efeito das alterações nas matérias primas ou no processamento tecnológico sobre o produto final, a graduação ou avaliação do nível de qualidade do produto final e testes de mercado para um novo produto entre outros.

A análise sensorial baseia-se em técnicas que são fundamentais na percepção psicológica e fisiológica. Esta ocorre quando o observador toma consciência da sensação. A percepção envolve a filtração, interpretação e reconstrução da vasta quantidade de informação que os receptores recebem. A mente armazena na memória as percepções, que são continuamente modificadas pelas novas percepções. Estas modificações são, de fato, o que nós chamamos de impressões. No processo total de percepção, os sinais, a integração e a interpretação não são facilmente separáveis. 
O grau de apreciação de um produto alimentício está ligado a este processo subjetivo, embora mais análise subjetiva possa ser feita pela introspecção e adoção consciente de uma atitude crítica. Os cinco sentidos ou receptores são utilizados na percepção do alimento, determinando a qualidade específica da percepção.

Todos esses testes devem ser realizados em locais tranqüilos, onde 0 analista fique livre de distúrbios e seja capaz de se concentrar. O experimentador necessita saber o que é percebido com o mínimo de interpretação subjetiva, de modo que os resultados possam ser relacionados significativamente com as medições mecânicas e instrumentais e com as pesquisas de mercado. Necessita, portanto, de condições especiais para fazer com que o degustador não julgue o produto com interpretações pessoais, mas o avalie o mais objetivamente possível. (DUTCOSKY, 1996)

Lacroix et al. (1993) analisou dois lotes de mangas da variedade Nahng Glahng Wahn, combinadas ou não, com banho térmico e doses de radiação gamma (0.49 a $0.77 \mathrm{KGy}$ ). Os resultados indicaram que para os dois tratamentos houve aumento no tempo de maturação da fruta. $\mathrm{O}$ grupo de mangas irradiadas sofreu um pequeno aumento na concentração de ácido ascórbico no primeiro dia após a radiação. $\mathrm{Na}$ análise sensorial, com o teste de escala hedônica, constataram-se diferenças significativas na textura e no "flavor" da polpa, com o seu enrigecimento, logo após a irradiação. No entanto, com o armazenamento e amadurecimento da fruta, observou-se amolecimento da polpa, resultando na maior aceitabilidade. Concluiu-se que a irradiação associada ou não com o banho térmico eleva o tempo de maturação da manga, sem afetar a sua aceitabilidade e qualidade sensorial.

O teste de aceitação tem por finalidade avaliar o grau de gostar ou desgostar de um determinado produto. Utiliza-se uma escala de dez pontos para avaliar a aceitação do provador em cada atributo testado. Ao numerar os intervalos de cada escala, garante-se que esses sejam iguais, padronizando-se assim, os intervalos entre as categorias e contribuindo para uma análise paramétrica dos dados (LAWLESS \& HEUMANN, 1999).

Neste teste é possível analisar uma série de atributos a partir de uma mesma amostra e desta forma consegue obter diversas informações sobre o produto. Para a realização deste teste, segundo Meilgaard et al. (1987), são 
necessários de 30 a 50 provadores, de preferência consumidores habituais ou potenciais do produto.

$O$ teste de intenção de compra tem por objetivo verificar o quanto 0 consumidor compraria ou não o produto apresentado, simulando uma situação real de compra de um produto de modo a reproduzir a ação do consumidor nos pontos de vendas. 


\section{Materiais e métodos}

\subsection{Materiais}

Para as análises físico-químicas, os materiais e equipamentos utilizados foram:

- Textura

Equipamento: Penetrômetro Manual, "Fruit Test FT”, marca Wagner Instruments.

- Sólidos Solúveis

Equipamento: Refratômetro de bancada tipo ABBE, Q-767B, marca Quimis Aparelhos Científicos Ltda.

\section{- Acidez Total}

Equipamento: Bureta Digital, "Digital Titration Apparatus”, marca Hirschmann Laborgerate $\mathrm{GmbH}$ \& Co. KG; Mixer, marca Mondial; pHmetro B474, marca Micronal.

Reagentes: Hidróxido de sódio $0,1 \mathrm{~N}$.

Materiais: Béquer $100 \mathrm{~mL}$ e de $500 \mathrm{~mL}$, água destilada.

$-p H$

Equipamento: pHmetro B474, marca Micronal.

- Perda de Massa (Lote 8 e lote 20)

Equipamento: balança semi-analítica, da marca Mettler, modelo PB 3002, Resolução 3100g.

Os equipamentos necessários para as análises encontram-se no Laboratório do Centro de Tecnologia das Radiações - CTR - IPEN-CNEN/SP.

Durante a análise sensorial, utilizou-se os seguintes materiais:

- Copos, pratos, garfos e guardanapos descartáveis;

- Bolacha água e sal;

- Água potável;

- Bombons; 


\subsection{Métodos}

\subsubsection{Parte experimental - Parte I}

- Recebimento das frutas

As mangas foram fornecidas por produtor da região de Petrolina. Essas foram enviadas por transporte aéreo. $O$ experimento foi constituído por dois envios, o primeiro constituído por frutas no estádio 2 e o segundo, no estádio 3. Cada lote apresentou em média 350 unidades da fruta. Os lotes foram enviados em dias distintos para facilitar a realização das análises. O propósito para as análises nos estádios distintos justifica-se na determinação do melhor estádio da fruta a ser colhida, posteriormente irradiada e exportada.

\section{- Fracionamento do lote e irradiação das frutas}

Após a chegada do lote, este foi fracionado em quatro partes. Uma delas serviu de controle, e as outras foram irradiadas nas doses de 0,20 kGy, 0,50 kGy e 0,75 kGy. O controle foi submetido, logo após a chegada das mangas, ás análises físico-químicas.

Paralelo a irradiação, foram escolhidas 8 mangas aleatoriamente dos frutos não irradiados (controle), e estas seguiram para o laboratório para os testes físico-químicos (Dia 0).

Para facilitar o acompanhamento do amadurecimento dos frutos, dividiramse as 350 mangas recebidas em duas frações: Lote 8 e Lote 20, respeitando as condições de temperatura de armazenamento definidas.

O Lote 20 foi composto por 20 unidades de frutas para cada dose, ou seja, 20 mangas para 0,75 kGy (Figura 4, Estádio 2), 20 para 0,50 kGy (Figura 6, Estádio 2), 20 para 0,20 kGy (Figura 5, Estádio 2) e a mesma quantidade para o controle (Figura 7, Estádio 2). Os frutos de cada porção foram individualmente numerados para facilitar na identificação e acompanhamento da maturação de cada.

Neste lote, acompanhou-se a cada 4 dias a perda de peso de cada fruta e o aparecimento de injúrias e podridões. 


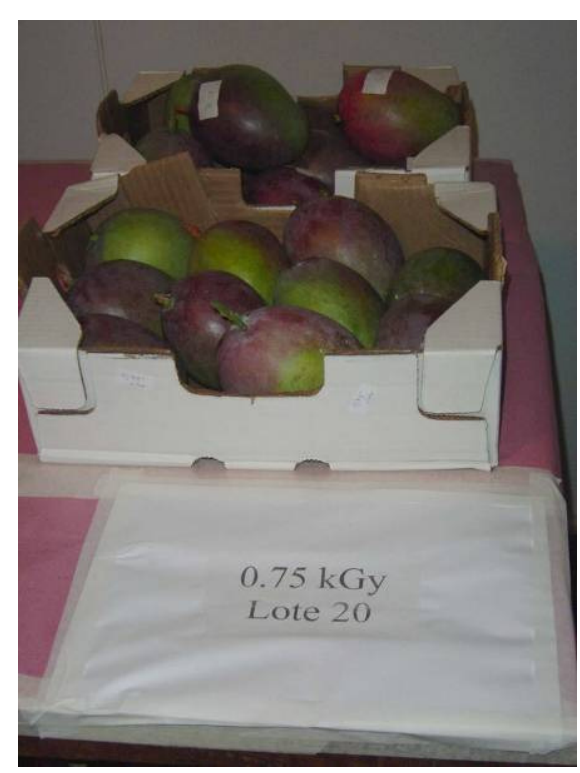

FIGURA 4 - Lote 20 - 0,75 kGy

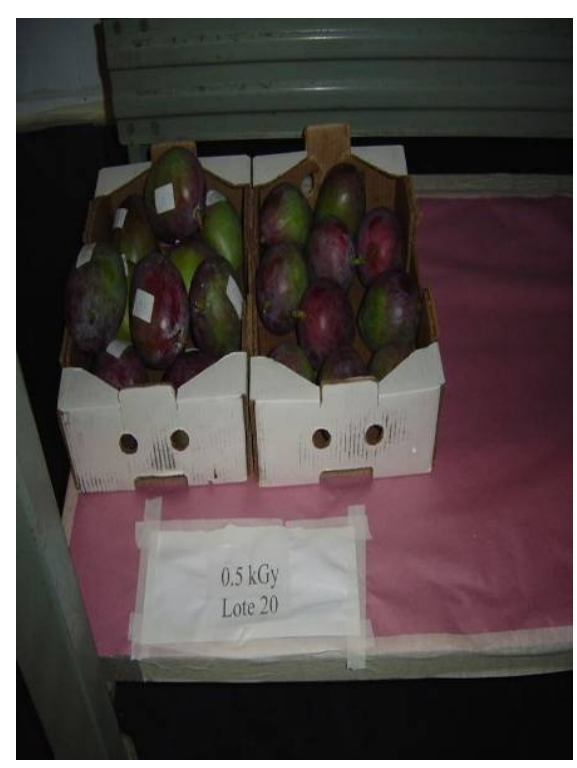

FIGURA 6 - Lote 20 - 0,5 kGy

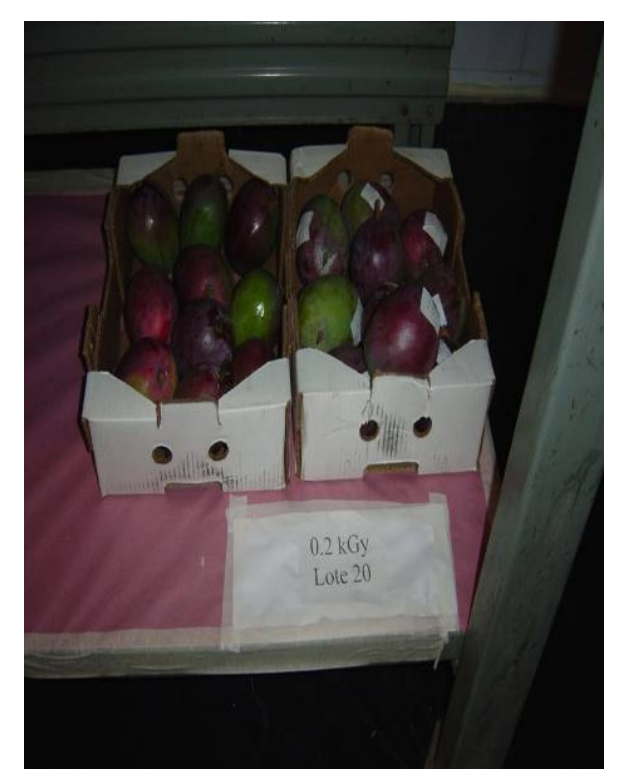

FIGURA 5 - Lote 20 - 0,2kGy

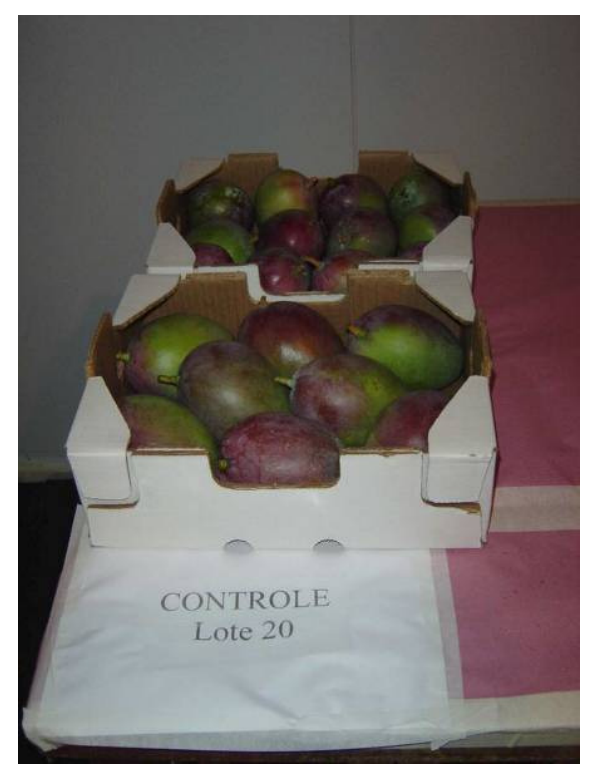

FIGURA 7 - Lote 20 - Controle

O restante das mangas, denominado Lote 8 , foi dividido em Controle (Figura 11, Estádio 2), 0,75 kGy (Figura 8, Estádio 2), 0,20 kGy (Figura 9, Estádio 2) e 0,50 kGy (Figura 10, Estádio 2), e seguiram conforme cronograma definido para as análises físico-químicas. 


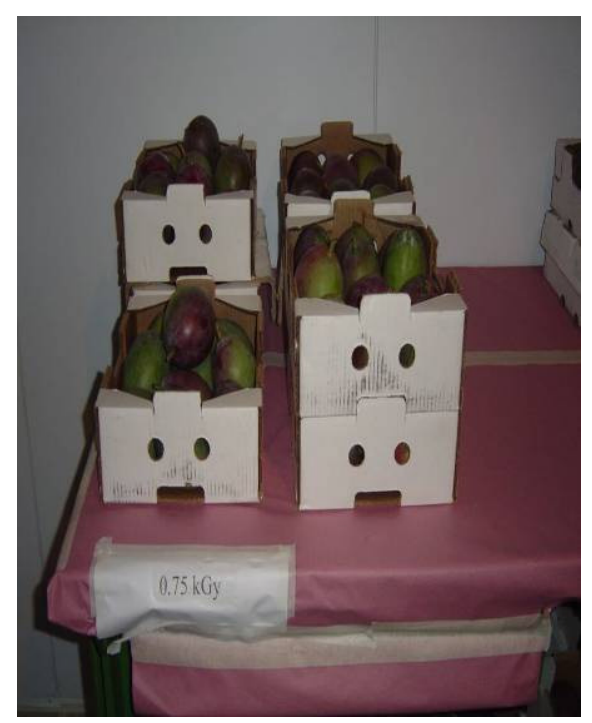

FIGURA 8 - Lote 8 - 0,75 kGy

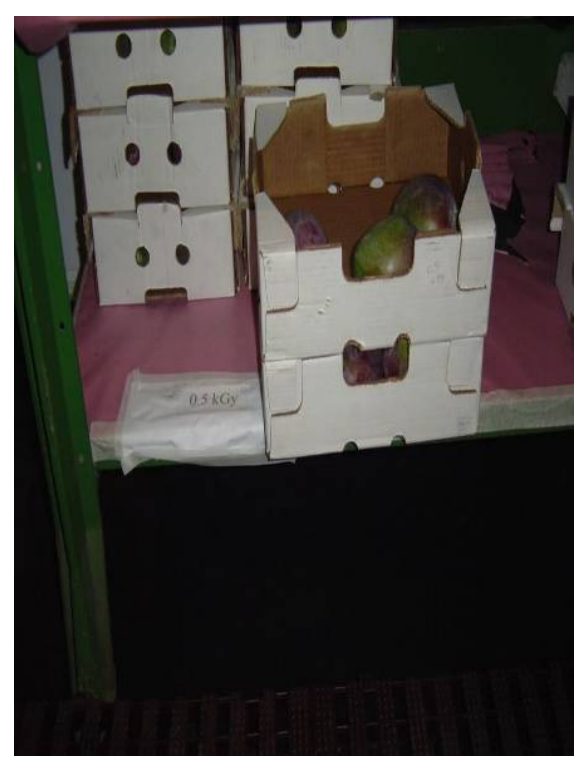

FIGURA 10 - Lote 8 - 0,2 kGy

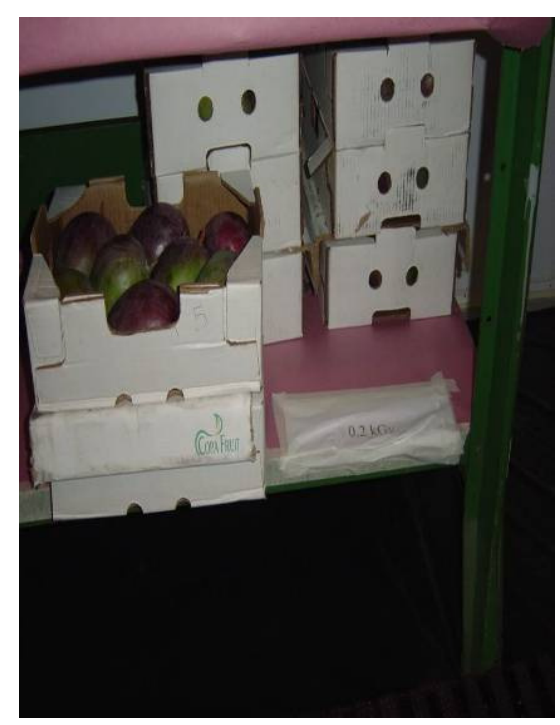

FIGURA 9 - Lote 8 - 0,2kGy

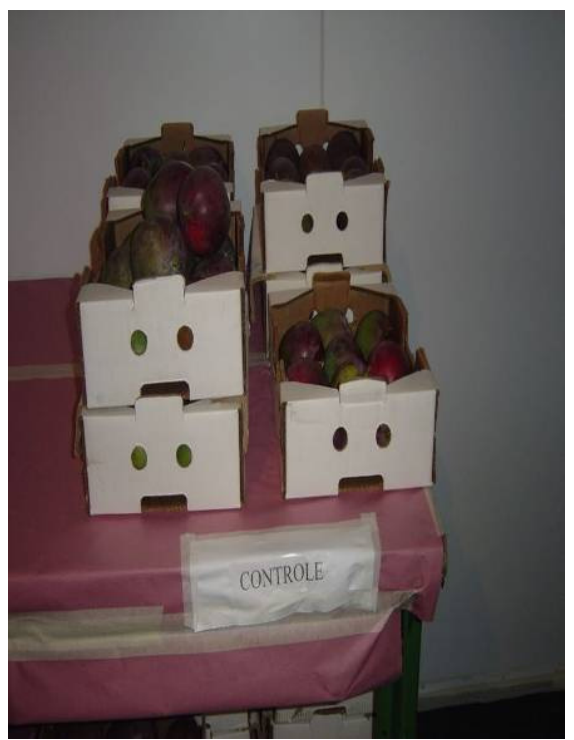

FIGURA 11 - Lote 8 - Controle

Para a irradiação das frutas, utilizou-se as fontes de Cobalto-60 do Irradiador Multipropósito, do Centro de Tecnologia das Radiações do IPENCNEN/SP, construído com auxílio Fapesp (Processo $n^{\circ}$. 97/07136-0). Todas as amostras foram devidamente codificadas de acordo com o tratamento a que foram submetidas.

Na Figura 12 encontramos a disposição geométrica com que as frutas foram colocadas no Irradiador.

A dosimetria foi realizada com o dosímetro de rotina Amber (Harwell, United Kingdon), e a taxa de dose foi estabelecida com o dosímetro de Fricke 
para traçar as curvas de calibração. Todo sistema dosimétrico empregado é reconhecido pelo programa IDAS da International Atomic Energy Agency.

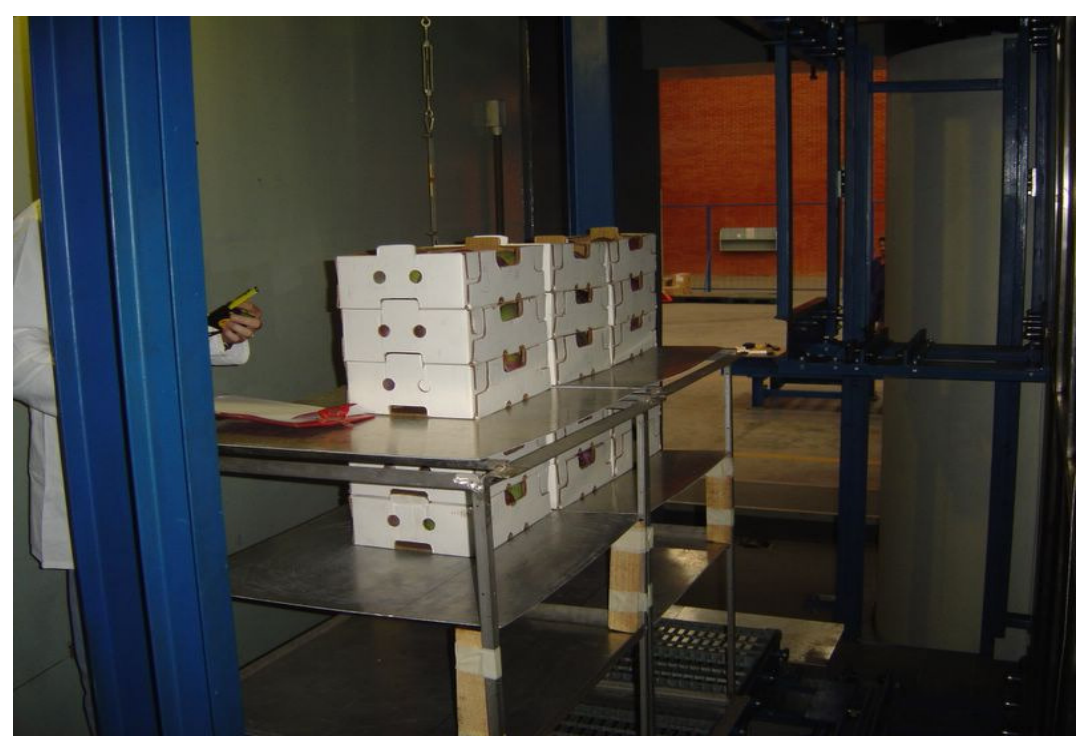

FIGURA 12 - Frutas no Irradiador Multipropósito

\section{-Amostragem}

Para cada dia de análise, retirou-se 8 mangas de cada fração, totalizando assim 32 frutos para todas as análises físico-químicas.

Por exemplo:

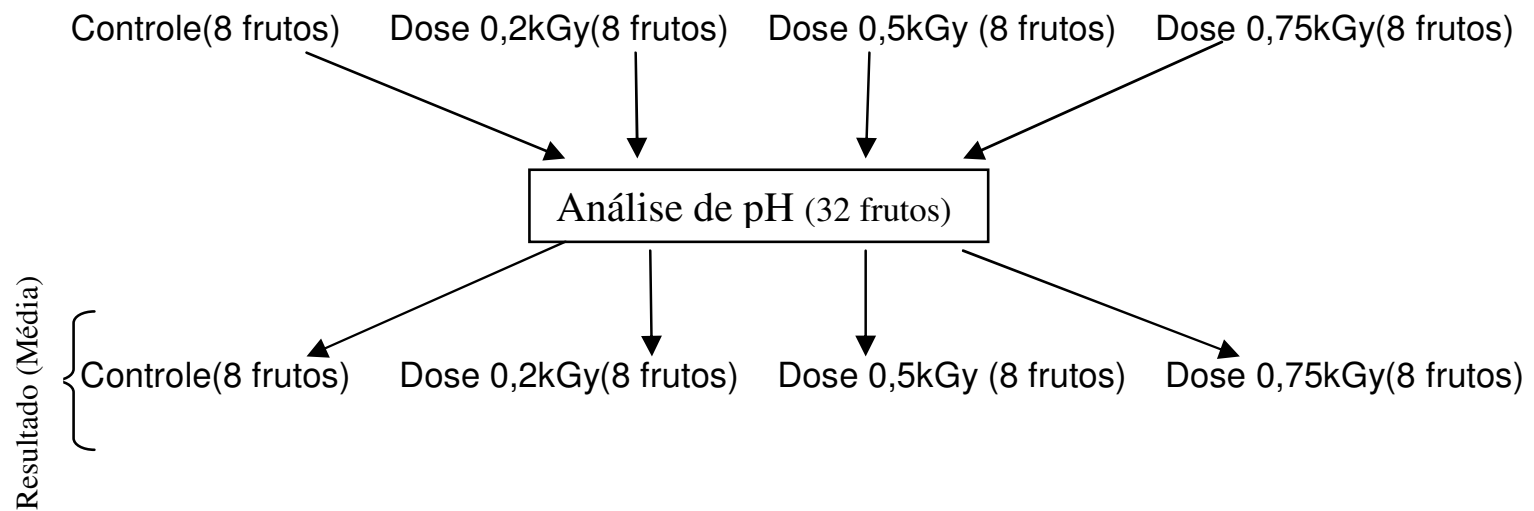

- Acondicionamento a $12^{\circ} \mathrm{C}$

Ao término do processo de irradiação, as mangas foram armazenadas, juntamente com o controle, em uma câmara fria a $12^{\circ} \mathrm{C}$, simulando, assim, o processo de refrigeração que ocorre durante o transporte da fruta. Num período 
de 14 dias, as mangas permaneceram armazenadas sob esta condição, e a cada 7 dias o lote 8 foi analisado físico-quimicamente.

- Acondicionamento a $25^{\circ} \mathrm{C}$

Ao fim da fase de refrigeração, as mangas foram acondicionadas a temperatura ambiente $\left(25^{\circ} \mathrm{C}\right)$ durante aproximadamente 14 dias, verificando-se a duração do tempo de vida útil da fruta. Nesta etapa, a análise das frutas ocorreu a cada 3 dias, até o início do processo de deterioração. 


\subsubsection{Fluxograma da parte experimental - Parte I}

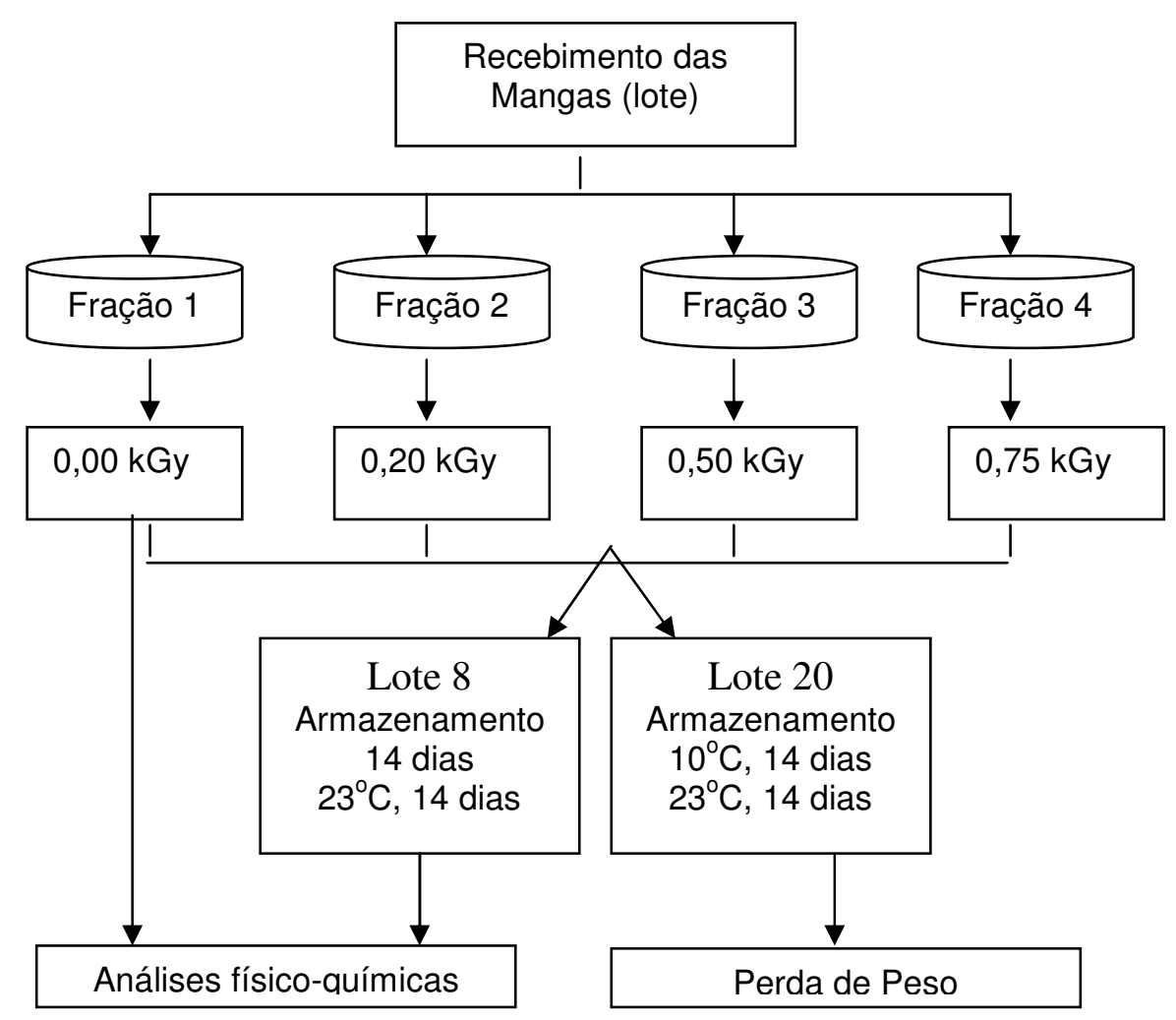

\subsection{Análises físico-químicas}

De cada fração, utilizou-se para cada período de análises físico-químicas, 8 frutas, totalizando com as quatro frações 32 mangas. A seguir, seguem a análises físico-químicas:

\section{- Cor da Casca}

A coloração da casca foi determinada através da escala de notas, variando de 1 a 5 (Figura 13) onde 1= Fruto verde com laivos arroxeados; $2=$ Fruto verde com leve pigmentação amarela; $3=$ Fruto com $1 / 3$ a 1/2 da superfície amarelada, com traços avermelhados e numerosas lenticelas; 4= Fruto com cerca de 2/3 da superfície amarelada, com traços avermelhados e numerosas lenticelas amarelas; $5=$ Fruto de cor laranja-amarelada com laivos vermelho-brilhantes na superfície. A padronização da cor da casca seguiu o critério de classificação do produtor. 


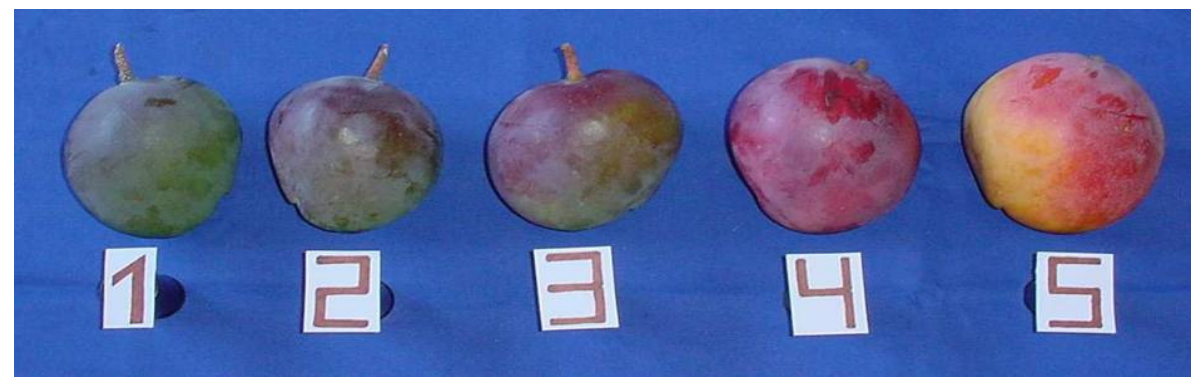

FIGURA 13 - Padrões da Cor da Casca

\section{- Cor da Polpa}

Foi obtida utilizando-se a escala de notas, variando de 1 a 5 (Figura 14)1= Branco, 2=Branco-amarelado; 3= Amarelo; 4= Amarelo-laranja; 5= Laranja. A padronização da cor da polpa seguiu o critério de classificação do produtor.

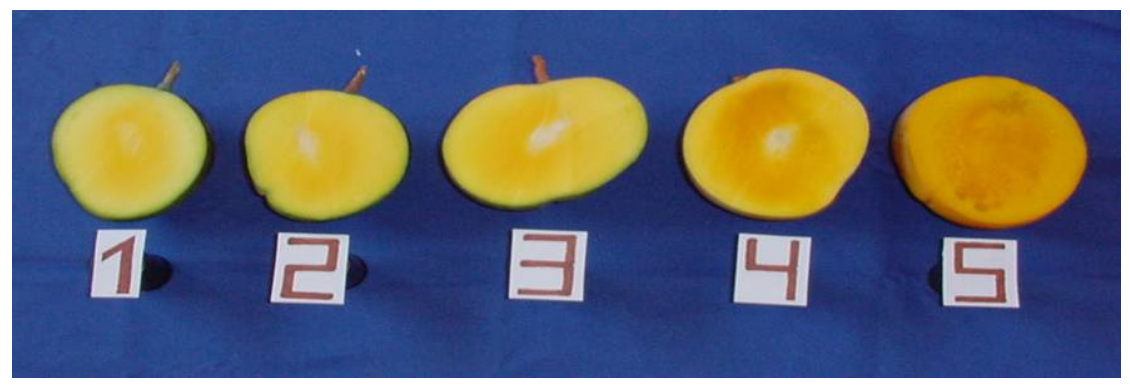

FIGURA 14 - Padrões da Cor da Polpa

\section{- Textura}

A textura das mangas resultou do uso de um penetrômetro manual, com escala de $0-13 \mathrm{~kg}$ e ponteira de $8 \mathrm{~mm}$, procedendo-se leitura na seção equatorial dos frutos, após a remoção de uma porção de casca. O valor obtido da textura foi definido pelo máximo de força requerida para que uma parte da ponteira penetre na polpa da manga.

\section{- Sólidos Solúveis}

Realizou-se através da leitura refratométrica direta em graus Brix, e correção de temperatura a $20^{\circ} \mathrm{C}$. Na medida em que os frutos foram abertos, coletou-se suco suficiente para se realizar a leitura no aparelho. 
- Acidez Total

O conteúdo de acidez titulável expresso em gramas de ácido cítrico foi determinado através da titulação de 10 gramas de polpa homogeneizada com um Mixer e diluída em $100 \mathrm{ml}$ de água destilada, apresentando como ponto de viragem o $\mathrm{pH} 8,1$. AOAC (1995)

$-p H$

A leitura de $\mathrm{pH}$ foi realizada com o mesmo aparelho utilizado para a determinação da acidez titulável, trocando-se apenas o tipo de eletrodo. Antes da adição do hidróxido de sódio $0,1 \mathrm{~N}$, fez-se a leitura no pHmetro.

- Perda de Massa

As amostras foram medidas em balança semi-analítica previamente calibrada.

\section{- Decomposição}

A decomposição foi avaliada através da quantidade de frutas descartadas no lote 20 , ou seja, porcentagem de mangas que se encontravam na senescência, podridão.

\subsection{Análise Sensorial - Parte II}

Nesta etapa, foi realizada a análise sensorial da manga no Estádio 3. Preferiu-se esse estádio, pois as frutas encontram-se mais maduras e mais próximas dos atributos visuais encontrados nas gôndolas dos supermercados. A análise ocorreu um dia após o tratamento por irradiação. Foram utilizadas amostras nas doses 0,5 kGy, 0,75 kGy e controle. O painel ocorreu com 48 provadores do sexo masculino e feminino, faixa etária entre 18 e 55 anos, no Laboratório de Análise Sensorial da Faculdade de Ciências Farmacêuticas da USP. Primeiramente, os provadores receberam uma ficha (Figura 15) para cadastro e posterior análise do perfil dos provadores presentes no teste sensorial. 
Nome:

Sexo: $\mathrm{F}$

Idade:

Abaixo de 18 anos

18 até 25 anos

$\square 25$ até 40 anos

$\square$ Acima 40 anos

Escolaridade:

1 1․ Grau

$2^{2} \stackrel{\circ}{ }$. Grau

\3‥ Grau (Incompleto)

$\square$ 3‥ Grau (Completo)

Com que freqüência você come manga?

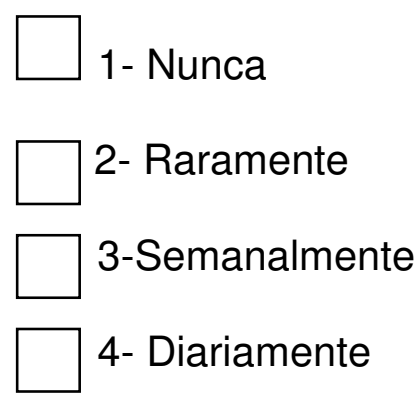

Que nota você atribui aos seus conhecimentos sobre irradiação de alimentos (Assinale uma alternativa):

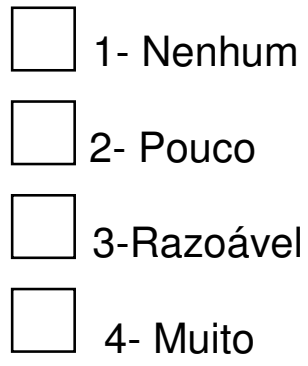

Comentários:

Figura 15 - Ficha de Cadastro do Provador 
Em seguida, aplicou-se o Teste de Aceitação em que as amostras foram oferecidas aos provadores para avaliação dos seguintes atributos: cor, odor, sabor e textura do produto, através da escala hedônica híbrida de $10 \mathrm{~cm}(0=$ desgostei muitíssimo; 5 = não gostei/nem desgostei; 10 = gostei muitíssimo). Nesta etapa havia espaço na ficha para comentários do que mais gostou ou desgostou (Figura 16).

Cada uma das três amostras foi servida em fatias, porção da polpa, a $25^{\circ} \mathrm{C}$. Os materiais utilizados resumiram-se em pratos descartáveis codificados (um código para cada amostra), seguidos de garfo e guardanapos descartáveis, biscoito água e sal, água mineral. Cada uma foi apresentada aos provadores de forma monádica (1 amostra por vez, sem comparação direta), seguindo um delineamento experimental de blocos completos casualizados. 


\section{Ficha de Avaliação Sensorial}

Nome:

Data:

\section{Amostra}

Você está recebendo uma amostra de Manga.

Marque com um " $X$ " na escala correspondente o lugar (inclusive entre os pontos) que melhor represente o quanto você gostou ou desgostou:

1. COR:

Desgostei Muitíssimo Nem gostei,Nem desgostei $\quad$ Gostei muitíssimo

2.ODOR:

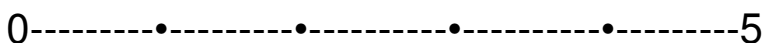

5

Nem gostei,Nem desgostei

Desgostei Muitíssimo muitíssimo

Gostei

3. SABOR:

0

Desgostei Muitíssimo

5

Nem gostei,Nem desgostei

muitíssimo

Gostei

4. TEXTURA :

0 5

Nem gostei,Nem desgostei

Desgostei Muitíssimo muitíssimo

Comentários:

Figura 16 - Ficha de Avaliação Sensorial: Teste de Aceitação

Após este, realizou-se o Teste da Intenção de Compra (Figura 17) cuja finalidade foi avaliar se os provadores do painel, após a degustação do produto com o teste anterior, comprariam a manga irradiada ou não. Como escala, foi adotada a hedônica de 5 pontos onde: $1=$ Certamente não compraria; 2 = Provavelmente não compraria; 3 = Talvez compra-se/ Talvez não compra-se; 4 = Provavelmente compraria; 5 = Certamente compraria. 
Para cada provador foram apresentadas duas mangas inteiras identificadas como irradiada e a outra não irradiada para o Teste de Intenção de Compra. A escolha dos frutos baseou-se na similaridade dos atributos visuais para que esses não interferissem na análise visual final.

\section{TESTE DE INTENÇÃO DE COMPRA MANGA IRRADIADA}

Nome: Data:

A manga apresentada foi irradiada com baixa dose de irradiação para o controle de pragas e aumentar o tempo de vida útil do produto. O processo de irradiação é seguro e a irradiação de alimentos é permitida pela Organização Mundial da Saúde.

Se você encontrar esta fruta em uma rede de supermercados e considerando que o preço da manga irradiada seja igual ao da não irradiada, avalie o produto apresentado e marque com um $X$, na escala abaixo, a sua intenção de compra deste produto.

1. Certamente não compraria

2. Provavelmente não compraria

3. Talvez compra-se/ Talvez não compra-se

4. Provavelmente compraria

5. Certamente Compraria

Justifique o porquê de sua resposta:

Figura 17 - Teste de Intenção de Compra 


\section{Resultados e Discussão}

\subsection{Resultados}

\subsubsection{Análise dos Resultados}

Os dados obtidos na parte experimental, parte 1, foram submetidos à análise estatística com auxílio do programa Statistica (Statistic 5.1, Statsoft, 1998), incluindo os testes: ANOVA e Duncan test (grupos homogêneos, alpha = 0,05 , interação $1 \times 2$ ). Este último está apresentado através de Tabelas. Apenas a análise de decomposição (lote 20) foi tratada através de gráficos de dispersão.

Para a parte 2, análise sensorial, a análise estatística do teste de aceitação foi realizada através de análise de variância de dois fatores (amostras e provadores) e teste de médias de Tukey, ao nível de $5 \%$ de significância.

\subsubsection{Parte Experimental - Parte 1}

Nesta etapa, os dados e resultados estatísticos estão agrupados conforme o tipo de análise físico-química, ou seja, para a textura há resultados do estádio 2 e 3, assim como para a cor da polpa, cor da casca, acidez titulável, sólidos solúveis e perda de massa.

Para as mangas do estádio 2, as frutas foram colhidas e enviadas em seguida para estudo. Entretanto para o estádio de maturação 3, as frutas só foram enviadas após cinco dias de colhidas, conforme nos informou o produtor no final do experimento. Consequentemente o resultado das análises oscilou entre os dias de análise. As etapas em que os dados foram tratados até o dia 24 indicam que não havia mais frutas suficientes para estudo neste período, em razão do número limitado de 350 frutos e do apodrecimento. 


\subsubsection{Resultados do lote 8}

\subsection{Cor da Casca}

- Estádio 2

De acordo com o Duncan Test (Tabela 4) pode-ser constatar que existe diferença significativa para a maioria das médias encontradas para cada dose e dia de análise em relação a cor da casca dos frutos.

No entanto, ao passarmos os dados para a forma de gráfico (Gráfico 1) verifica-se que há similaridade na variação das médias para as mangas irradiadas, ou seja, a maturação na cor da casca destes frutos ocorre de forma parecida. No dia 17, as mangas irradiadas atingem a coloração 4, enquanto que a controle encontra-se, conforme este atributo, madura e com cor igual a 5.

Para o dia 24, pode ser observado que a coloração da casca encontra-se mais intensa (avermelhada) para o controle do que em relação a Dose 0,75kGy.

\section{- Estádio 3}

No estádio 3, a cor da casca não apresentou diferença significativa entre as amostras para o dia 7. De uma maneira geral, para cada dia de análise, a diferença é acentuada para as amostras controle em relação as irradiadas.

Porém, deve ser considerado que neste estádio as mangas já estavam maduras, fator que aproxima os frutos da senescência.

Conforme o Gráfico 2 verifica-se que a partir do dia 14 a amostra controle manteve-se com a cor da casca constante, enquanto que os frutos irradiados apresentam variações no amadurecimento.

No dia 24, observa-se que a dose 0,75kGy contribuiu para um retardo na coloração da casca. 
Tabela 4 - Duncan Test - Estádio 2

\begin{tabular}{|c|c|c|}
\hline \multicolumn{3}{|c|}{ COR DA CASCA } \\
\hline Dia & Dose & $\begin{array}{c}\text { Média e Desvio } \\
\text { Padrão }\end{array}$ \\
\hline DIA 0 & Controle & $2,25^{\mathrm{ab}} \pm 0,71$ \\
\hline DIA 1 & Controle & $2,37^{\mathrm{abc}} \pm 0,52$ \\
\hline DIA 1 & Dose 0,2 & $2,37^{a b c} \pm 0,74$ \\
\hline DIA 1 & Dose 0,5 & $2,75^{\mathrm{bcd}} \pm 0,46$ \\
\hline DIA 1 & Dose 0,75 & $1,75^{a} \pm 0,71$ \\
\hline DIA 7 & Controle & $3,12^{\text {def }} \pm 1,36$ \\
\hline DIA 7 & Dose 0,2 & $4,00^{\text {ghijl }} \pm 0,76$ \\
\hline DIA 7 & Dose 0,5 & $3,50^{\text {efgh }} \pm 0,53$ \\
\hline DIA 7 & Dose 0,75 & $3,50^{\text {defgh }} \pm 0,53$ \\
\hline DIA 14 & Controle & $3,50^{\text {defgh }} \pm 0,76$ \\
\hline DIA 14 & Dose 0,2 & $3,00^{\mathrm{cde}^{\prime}} \pm 0,76$ \\
\hline DIA 14 & Dose 0,5 & $3,37^{\text {defg }_{ \pm}} 0,52$ \\
\hline DIA 14 & Dose 0,75 & $3,37^{\text {defg }_{ \pm}} 0,74$ \\
\hline DIA 17 & Controle & $5,00^{n} \pm 0,00$ \\
\hline DIA 17 & Dose 0,2 & $4,00^{\text {ghij }} \pm 0,93$ \\
\hline DIA 17 & Dose 0,5 & $3,75^{\text {efghi }} \pm 0,89$ \\
\hline DIA 17 & Dose 0,75 & $3,87^{\text {fghij }} \pm 0,99$ \\
\hline DIA 21 & Controle & $5,00^{n} \pm 0,00$ \\
\hline DIA 21 & Dose 0,2 & $5,00^{m n} \pm 0,00$ \\
\hline DIA 21 & Dose 0,5 & $4,12^{\text {ghijl }} \pm 0,99$ \\
\hline DIA 21 & Dose 0,75 & $4,50^{\mathrm{Imn}} \pm 0,76$ \\
\hline DIA 24 & Controle & $5,00^{\mathrm{mn}} \pm 0,00$ \\
\hline DIA 24 & Dose 0,2 & $4,62^{\mathrm{jlmn}} \pm 0,52$ \\
\hline DIA 24 & Dose 0,5 & $4,75^{\mathrm{lmn}} \pm 0,46$ \\
\hline DIA 24 & Dose 0,75 & $4,25^{\text {hijlm }} \pm 0,89$ \\
\hline
\end{tabular}

Tabela 5 - Duncan Test - Estádio 3

\begin{tabular}{|c|c|c|}
\hline \multicolumn{3}{|c|}{ COR DA CASCA } \\
\hline Dia & Dose & $\begin{array}{l}\text { Média e Desvio } \\
\text { Padrão }\end{array}$ \\
\hline DIA 0 & Controle & $4,62^{\mathrm{de}} \pm 0,52$ \\
\hline DIA 1 & Controle & $4,62^{\mathrm{de}} \pm 0,52$ \\
\hline DIA 1 & Dose 0,2 & $3,25^{b c} \pm 0,89$ \\
\hline DIA 1 & Dose 0,5 & $3,62^{c d} \pm 0,74$ \\
\hline DIA 1 & Dose 0,75 & $3,62^{\mathrm{cd}} \pm 1,06$ \\
\hline DIA 7 & Controle & $4,50^{\text {cde }} \pm 0,76$ \\
\hline DIA 7 & Dose 0,2 & $4,25^{\mathrm{cde}} \pm 0,89$ \\
\hline DIA 7 & Dose 0,5 & $4,25^{\mathrm{cde}} \pm 0,89$ \\
\hline DIA 7 & Dose 0,75 & $4,37^{\mathrm{cde}} \pm 0,74$ \\
\hline DIA 14 & Controle & $5,00^{\mathrm{e}} \pm 0,00$ \\
\hline DIA 14 & Dose 0,2 & $4,25^{\mathrm{cde}} \pm 0,89$ \\
\hline DIA 14 & Dose 0,5 & $4,37^{\mathrm{cde}} \pm 0,74$ \\
\hline DIA 14 & Dose 0,75 & $3,62^{\mathrm{cd}} \pm 0,74$ \\
\hline DIA 17 & Controle & $5,00^{e} \pm 0,00$ \\
\hline DIA 17 & Dose 0,2 & $4,57^{\mathrm{cde}} \pm 0,53$ \\
\hline DIA 17 & Dose 0,5 & $4,75^{\mathrm{de}} \pm 0,46$ \\
\hline DIA 17 & Dose 0,75 & $3,75^{\mathrm{cde}} \pm 0,71$ \\
\hline DIA 21 & Controle & $5,00^{\mathrm{e}} \pm 0,00$ \\
\hline DIA 21 & Dose 0,2 & $4,14^{\mathrm{cde}} \pm 0,90$ \\
\hline DIA 21 & Dose 0,5 & $4,42^{\mathrm{cde}} \pm 0,53$ \\
\hline DIA 21 & Dose 0,75 & $3,75^{\mathrm{cde}} \pm 0,71$ \\
\hline DIA 24 & Controle & $5,00^{\text {cde }} \pm 0,00$ \\
\hline DIA 24 & Dose 0,2 & $4,50^{\mathrm{cde}} \pm 0,76$ \\
\hline DIA 24 & Dose 0,5 & $4,50^{\mathrm{ab}} \pm 0,58$ \\
\hline DIA 24 & Dose 0,75 & $4,33^{a} \pm 0,64$ \\
\hline
\end{tabular}

Obs.: Letras iguais indicam que não houve diferença significativa entre as amostras. 


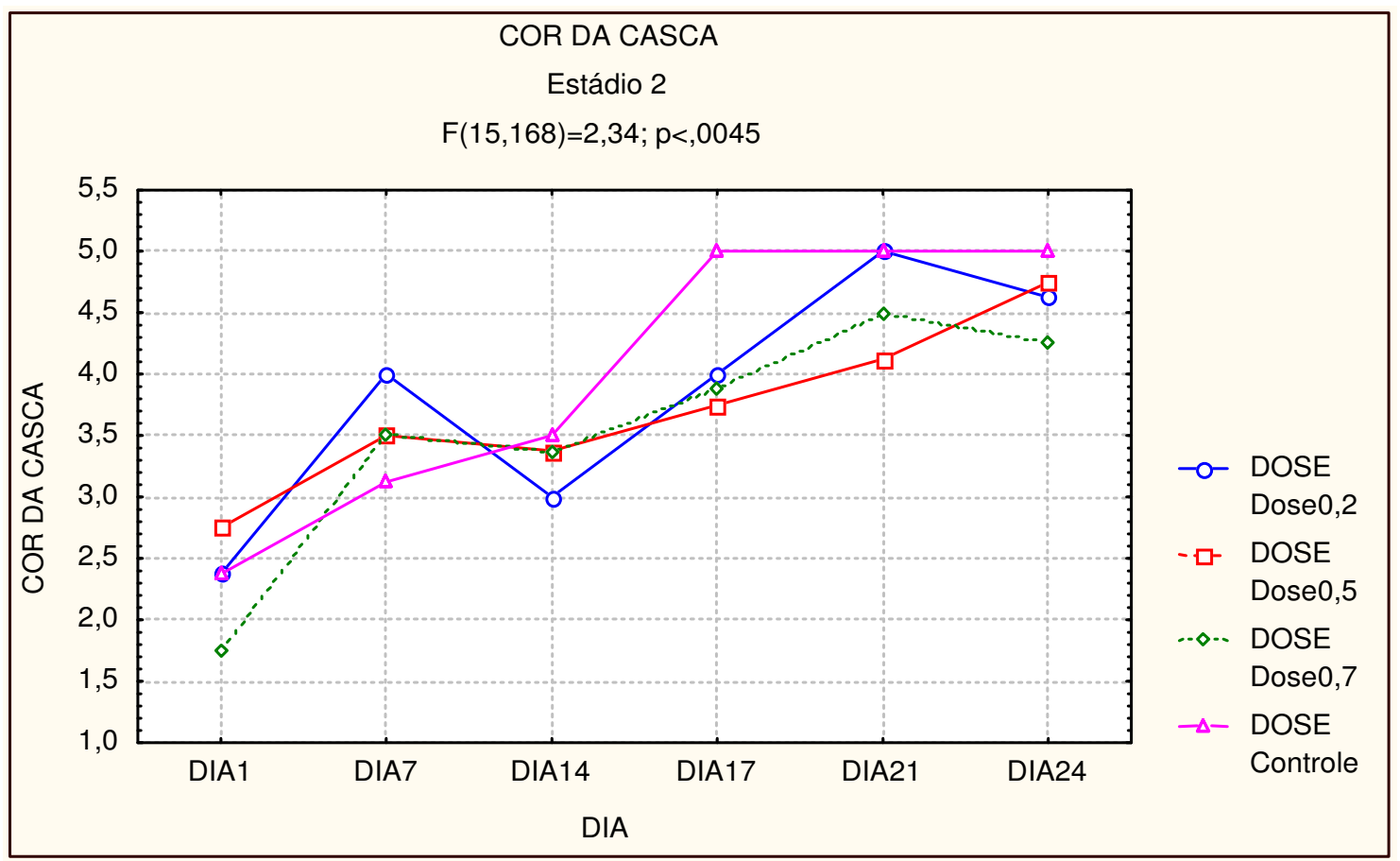

Gráfico 1 -Dias X Doses - Cor da Casca - Estádio 2

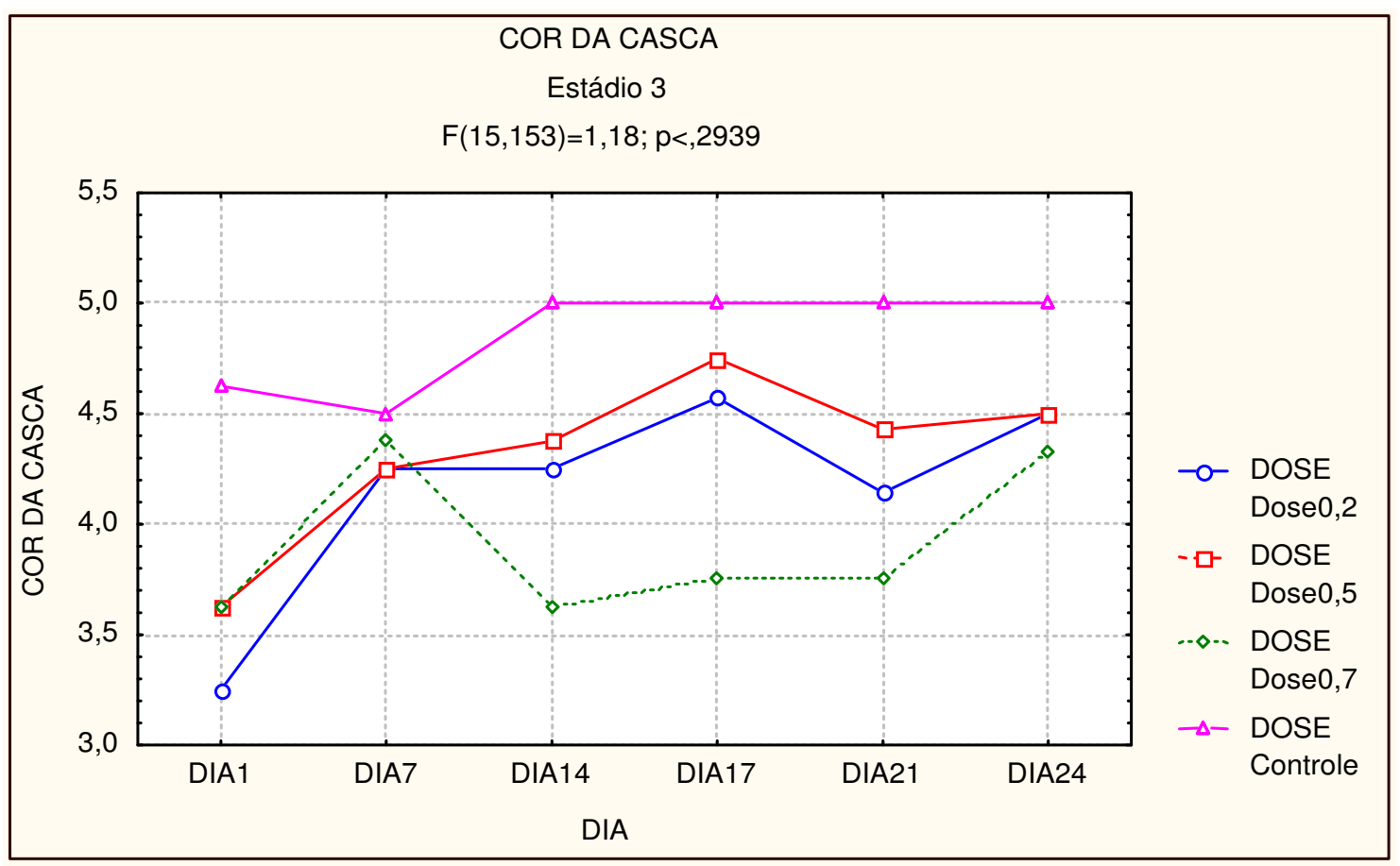

Gráfico 2 -Dias X Doses - Cor da Casca - Estádio 3 


\subsection{Cor da Polpa}

- Estádio 2

Para os dias de análise, verifica-se pelo Duncan Test (Tabela 6) que houve variação entre as médias da cor da polpa e as dosagens.

Analisando o Gráfico 3, as frutas oscilaram de maneira similar. Entretanto, observa-se que a partir do dia 17 , as mangas controle permaneceram com a coloração da polpa constante

Ao final do dia 24, é verificado que as mangas nas doses 0,2kGy e 0,5kGy apresentam coloração da polpa menos intensa. Porém, este fator é mais acentuado para a dose 0,75kGy, em que entre os dias 1 e 24 a variação da cor esteve entre 3,2 a 4,0 .

\section{- Estádio 3}

Após o Duncan Test (Tabela 7), observa-se que as médias da cor da polpa no estádio 3 apresentaram diferenças significativas entre as amostras.

Graficamente (Gráfico 4), entre os dias 7 e 17, a cor da polpa controle intensificou-se do ponto 3,5 ao 4,83.

Notoriamente, a dose 0,75kGy apresentou um melhor retardo na coloração, em que entre os dias 1 e 24 , variou entre 3,2 a 4,0. 
Tabela 6 - Duncan Test -Estádio 2

\begin{tabular}{|c|c|c|}
\hline \multicolumn{3}{|c|}{ COR DA POLPA } \\
\hline Dia & Dose & $\begin{array}{l}\text { Média e Desvio } \\
\text { Padrão }\end{array}$ \\
\hline DIA 0 & Controle & $1,71^{a} \pm 0,76$ \\
\hline DIA 1 & Controle & $1,75^{\mathrm{ab}} \pm 0,46$ \\
\hline DIA 1 & Dose 0,2 & $2,37^{\mathrm{abcd}} \pm 0,74$ \\
\hline DIA 1 & Dose 0,5 & $1,87^{\mathrm{abc}} \pm 0,64$ \\
\hline DIA 1 & Dose 0,75 & $1,87^{a b c} \pm 0,64$ \\
\hline DIA 7 & Controle & $3,12^{\mathrm{cde}} \pm 1,36$ \\
\hline DIA 7 & Dose 0,2 & $3,12^{\text {cde }} \pm 0,99$ \\
\hline DIA 7 & Dose 0,5 & $2,87^{\text {bcde }} \pm 1,36$ \\
\hline DIA 7 & Dose 0,75 & $2,62^{\mathrm{abcd}} \pm 1,06$ \\
\hline DIA 14 & Controle & $3,25^{\mathrm{de}} \pm 1,04$ \\
\hline DIA 14 & Dose 0,2 & $2,87^{\mathrm{bcde}} \pm 0,64$ \\
\hline DIA 14 & Dose 0,5 & $3,62^{\text {def }} \pm 0,92$ \\
\hline DIA 14 & Dose 0,75 & $3,62^{\text {def }} \pm 0,74$ \\
\hline DIA 17 & Controle & $5,00^{9} \pm 0,00$ \\
\hline DIA 17 & Dose 0,2 & $4,65^{\mathrm{fg}} \pm 0,74$ \\
\hline DIA 17 & Dose 0,5 & $4,87^{f g} \pm 0,35$ \\
\hline DIA 17 & Dose 0,75 & $4,00^{\text {efg }} \pm 0,76$ \\
\hline DIA 21 & Controle & $5,00^{g} \pm 0,00$ \\
\hline DIA 21 & Dose 0,2 & $5,00^{\mathrm{fg}} \pm 0,00$ \\
\hline DIA 21 & Dose 0,5 & $4,75^{\mathrm{fg}} \pm 0,46$ \\
\hline DIA 21 & Dose 0,75 & $4,80^{\mathrm{efg}} \pm 0,45$ \\
\hline DIA 24 & Controle & $5,00^{g} \pm 0,00$ \\
\hline DIA 24 & Dose 0,2 & $4,83^{\text {def }_{ \pm}} 0,41$ \\
\hline DIA 24 & Dose 0,5 & $4,83^{\text {def }} \pm 0,41$ \\
\hline DIA 24 & Dose 0,75 & $4,62^{f g} \pm 0,52$ \\
\hline
\end{tabular}

Tabela 7 - Duncan Test - Estádio 3

\begin{tabular}{llr}
\hline \multicolumn{2}{c}{ COR DA POLPA } \\
\hline Dia & Dose & $\begin{array}{c}\text { Média e Desvio } \\
\text { Padrão }\end{array}$ \\
\hline DIA 0 & Controle & \multicolumn{1}{c}{$4,00^{\text {cde }} \pm 0,53$} \\
\hline DIA 1 & Controle & $4,00^{\text {cde }} \pm 0,53$ \\
DIA 1 & Dose 0,2 & $3,62^{\text {cdef }} \pm 1,19$ \\
DIA 1 & Dose 0,5 & $3,75^{\text {cdef }} \pm 1,04$ \\
DIA 1 & Dose 0,75 & $3,33^{\text {abc }} \pm 0,52$ \\
\hline DIA 7 & Controle & $3,50^{\text {cdef }} \pm 1,07$ \\
DIA 7 & Dose 0,2 & $4,12^{\text {de }} \pm 0,64$ \\
DIA 7 & Dose 0,5 & $3,87^{\text {cde }} \pm 0,99$ \\
DIA 7 & Dose 0,75 & $3,85^{\text {cle }} \pm 1,21$ \\
\hline DIA 14 & Controle & $4,12^{\text {de }} \pm 0,83$ \\
DIA 14 & Dose 0,2 & $3,85^{\text {cdef }} \pm 1,07$ \\
DIA 14 & Dose 0,5 & $4,37^{\text {de }} \pm 0,74$ \\
DIA 14 & Dose 0,75 & $3,75^{\text {clef }} \pm 1,04$ \\
\hline DIA 17 & Controle & $4,85^{\text {de }} \pm 0,38$ \\
DIA 17 & Dose 0,2 & $4,71^{\text {de }} \pm 0,49$ \\
DIA 17 & Dose 0,5 & $4,62^{\text {de }} \pm 0,52$ \\
DIA 17 & Dose 0,75 & $3,50^{\text {cdef }} \pm 0,53$ \\
\hline DIA 21 & Controle & $4,87^{ \pm} \pm 0,35$ \\
DIA 21 & Dose 0,2 & $4,14^{\text {cde }} \pm 0,90$ \\
DIA 21 & Dose 0,5 & $4,42^{\text {cde }} \pm 0,53$ \\
DIA 21 & Dose 0,75 & $3,50^{\text {cdef }} \pm 0,53$ \\
\hline DIA 24 & Controle & $5,00^{\text {cdef }} \pm 0,00$ \\
DIA 24 & Dose 0,2 & $4,65^{\text {de }} \pm 0,52$ \\
DIA 24 & Dose 0,5 & $4,50^{\text {ab }} \pm 0,58$ \\
DIA 24 & Dose 0,75 & $4,00^{\text {a }} \pm 1,00$ \\
\hline
\end{tabular}

Obs.: Letras iguais indicam que não houve diferença significativa entre as amostras. 


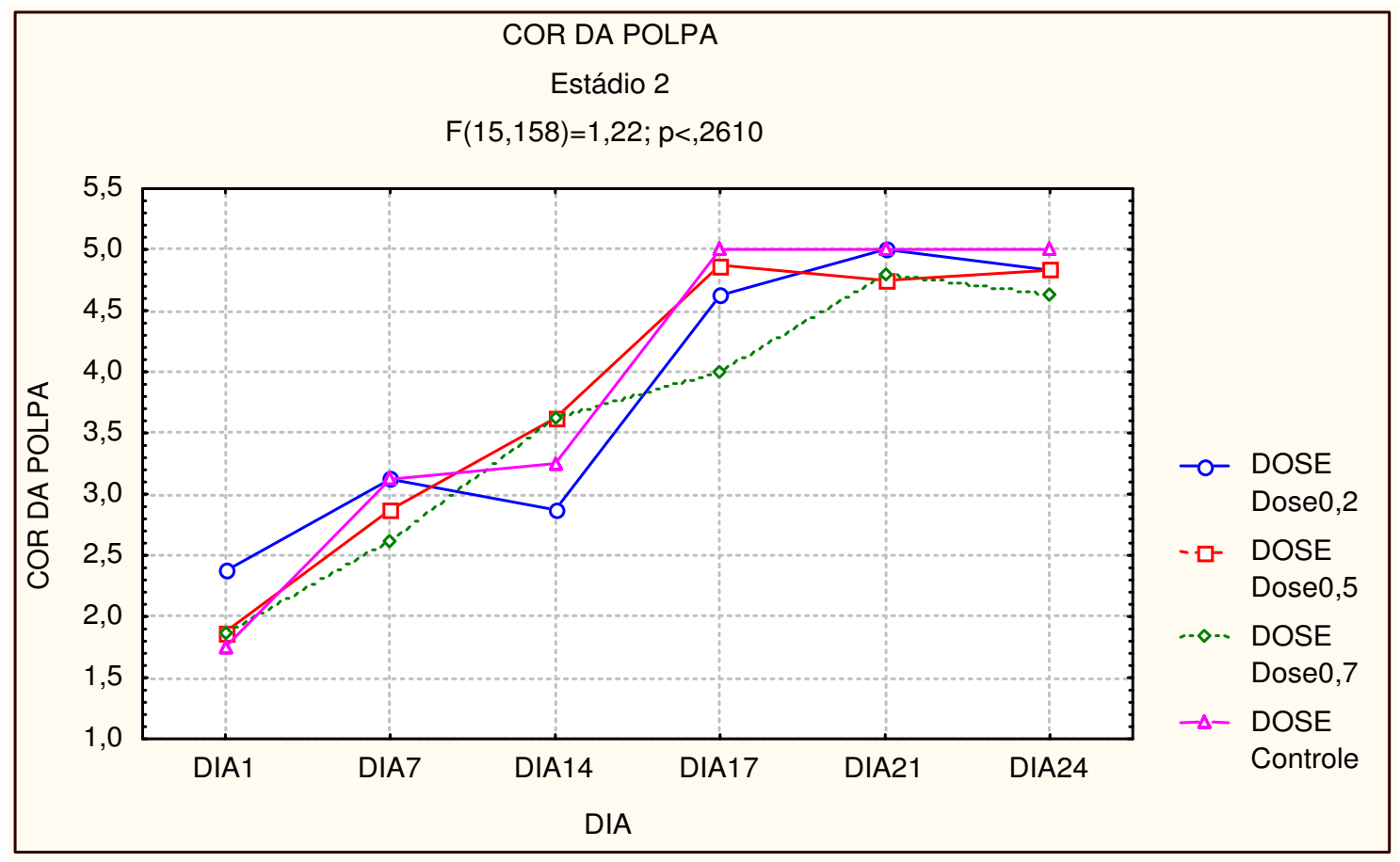

Gráfico 3 -Dias X Doses - Cor da Polpa - Estádio 2

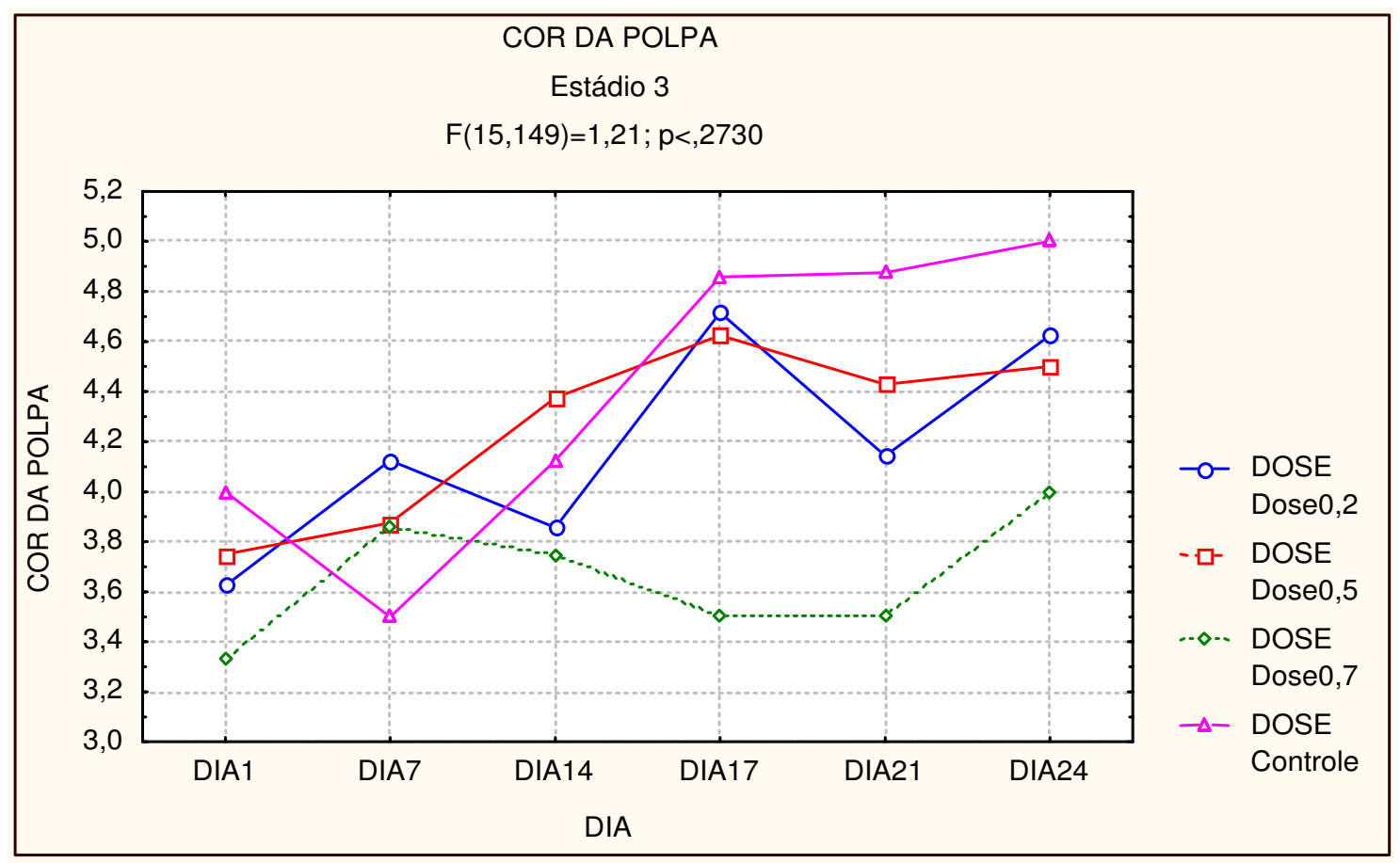

Gráfico 4 -Dias X Doses - Cor da Polpa - Estádio 3 


\subsection{Perda de Massa}

- Estádio 2

Em todos os resultados dos dias de análises, verificou-se que houve diferenças estatísticas para a perda de massa entre as doses, conforme revela o Tabela 8.

Através do Gráfico 5, a dose 0,5kGy e o controle apresentaram aumento de massa até o dia 7, e posteriormente iniciaram na perda de massa.

Para este parâmetro, o menor gradiente é o da dose 0,75kGy, em que o peso varia entre $450 \mathrm{~g}$ a $425 \mathrm{~g}$, durante 24 dias

\section{- Estádio 3}

Similar ao Estádio 2, no estádio 3 ocorreram diferenças significativas entre as médias das doses (Tabela 9).

Por outro lado, graficamente, a variação das médias não foi similar. De acordo com o Gráfico 6, o controle resultou em perda de massa mais rápida durante os 24 dias.

A dose $0,5 \mathrm{kG}$ y foi a mais uniforme perante as outras, porém culminou em um ponto final próximo a 0,75kGy.

Obs.: Para ambos os estádios, como trata-se de análise destrutiva, ou seja, os frutos não são os mesmos para os dias de análises, estes resultados podem ser melhores visualizados na perda de massa do lote 20 , pois os frutos foram codificados e pode-se observar o comportamento do mesmo fruto expresso em média. 
Tabela 8 - Duncan Test - Estádio 2

\begin{tabular}{|c|c|c|}
\hline \multicolumn{3}{|c|}{ PERDA DE MASSA (g) } \\
\hline Dia & Dose & $\begin{array}{c}\text { Média e Desvio } \\
\text { Padrão }\end{array}$ \\
\hline DIA 0 & Controle & $493,47^{\text {fghi }} \pm 35,48$ \\
\hline DIA 1 & Controle & $435,99^{\text {bcdefgh }_{ \pm}} 29,77$ \\
\hline DIA 1 & Dose 0,2 & $503,13^{\text {fghi }} \pm 53,01$ \\
\hline DIA 1 & Dose 0,5 & $448,55^{\text {bcdefgh }} \pm 18,51$ \\
\hline DIA 1 & Dose 0,75 & $447,30^{\text {bcdefgh }} \pm 35,06$ \\
\hline DIA 7 & Controle & $574,91^{i} \pm 12,65$ \\
\hline DIA 7 & Dose 0,2 & $509,76^{\text {gghi }} \pm 54,78$ \\
\hline DIA 7 & Dose 0,5 & $530,26^{\mathrm{hi}} \pm 55,41$ \\
\hline DIA 7 & Dose 0,75 & $421,89^{\text {bcdef }} \pm 93,78$ \\
\hline DIA 14 & Controle & $520,26^{\text {ghi }} \pm 27,41$ \\
\hline DIA 14 & Dose 0,2 & $384,71^{\mathrm{abcde}} \pm 122,09$ \\
\hline DIA 14 & Dose 0,5 & $509,61^{\mathrm{fghi}} \pm 36,92$ \\
\hline DIA 14 & Dose 0,75 & $471,87^{\text {defgh }} \pm 43,76$ \\
\hline DIA 17 & Controle & $472,37^{\text {defgh }} \pm 83,99$ \\
\hline DIA 17 & Dose 0,2 & $453,15^{\text {cdefgh }} \pm 37,79$ \\
\hline DIA 17 & Dose 0,5 & $478,67^{\text {efgh }} \pm 51,82$ \\
\hline DIA 17 & Dose 0,75 & $370,46^{\mathrm{abc}} \pm 150,99$ \\
\hline DIA 21 & Controle & $467,83^{\text {defgh }} \pm 64,94$ \\
\hline DIA 21 & Dose 0,2 & $437,49^{\text {bcdefgh }} \pm 19,56$ \\
\hline DIA 21 & Dose 0,5 & $418,55^{\text {bcdefgh }} \pm 57,11$ \\
\hline DIA 21 & Dose 0,75 & $319,93^{a} \pm 202,76$ \\
\hline DIA 24 & Controle & $434,26^{\text {bcdefgh }} \pm 48,61$ \\
\hline DIA 24 & Dose 0,2 & $355,76^{\mathrm{ab}} \pm 147,33$ \\
\hline DIA 24 & Dose 0,5 & $380,80^{\mathrm{abcd}} \pm 159,07$ \\
\hline DIA 24 & Dose 0,75 & $423,55^{\text {bcdef }} \pm 59,92$ \\
\hline
\end{tabular}

Tabela 9 - Duncan Test - Estádio 3

\begin{tabular}{llr}
\hline & PERDA DE MASSA (g) \\
\hline Dia & Dose & $\begin{array}{c}\text { Média e Desvio } \\
\text { Padrão }\end{array}$ \\
\hline DIA 0 & Controle & $443,28^{\text {defg }} \pm 15,23$ \\
\hline DIA 1 & Controle & $443,27^{\text {defg }} \pm 15,23$ \\
DIA 1 & Dose 0,2 & $354,82^{\text {cde }} \pm 13,07$ \\
DIA 1 & Dose 0,5 & $417,89^{\text {cdefg }} \pm 24,02$ \\
DIA 1 & Dose 0,75 & $437,59^{\text {defg }} \pm 22,58$ \\
\hline DIA 7 & Controle & $504,52^{\text {ffg }} \pm 39,35$ \\
DIA 7 & Dose 0,2 & $337,46^{\text {cde }} \pm 22,17$ \\
DIA 7 & Dose 0,5 & $426,81^{\text {defg }} \pm 17,46$ \\
DIA 7 & Dose 0,75 & $494,21^{\text {fg }} \pm 21,82$ \\
\hline DIA 14 & Controle & $513,62^{\mathrm{g}} \pm 21,13$ \\
DIA 14 & Dose 0,2 & $415,31^{\text {cdefg }} \pm 50,95$ \\
DIA 14 & Dose 0,5 & $433,08^{\text {defg }} \pm 17,75$ \\
DIA 14 & Dose 0,75 & $434,75^{\text {defg }} \pm 26,64$ \\
\hline DIA 17 & Controle & $348,29^{\text {cde }} \pm 216,54$ \\
DIA 17 & Dose 0,2 & $283,81^{\text {bc }} \pm 116,78$ \\
DIA 17 & Dose 0,5 & $412,29^{\text {cdefg }} \pm 14,82$ \\
DIA 17 & Dose 0,75 & $472,88^{\text {efg }} \pm 102,88$ \\
\hline DIA 21 & Controle & $391,56^{\text {cdefg }} \pm 163,96$ \\
DIA 21 & Dose 0,2 & $289,97^{\text {bc }} \pm 181,54$ \\
DIA 21 & Dose 0,5 & $313,30^{\text {bcd }} \pm 194,10$ \\
DIA 21 & Dose 0,75 & $312,47^{\text {bcd }} \pm 194,76$ \\
\hline DIA 24 & Controle & $292,33^{\text {bc }} \pm 181,37$ \\
DIA 24 & Dose 0,2 & $374,31^{\text {cdef }} \pm 140,33$ \\
DIA 24 & Dose 0,5 & $203,76^{\text {ab }} \pm 218,34$ \\
DIA 24 & Dose 0,75 & $154,38^{\text {a }} \pm 213,19$ \\
\hline
\end{tabular}

Obs.: Letras iguais indicam que não houve diferença significativa entre as amostras. 


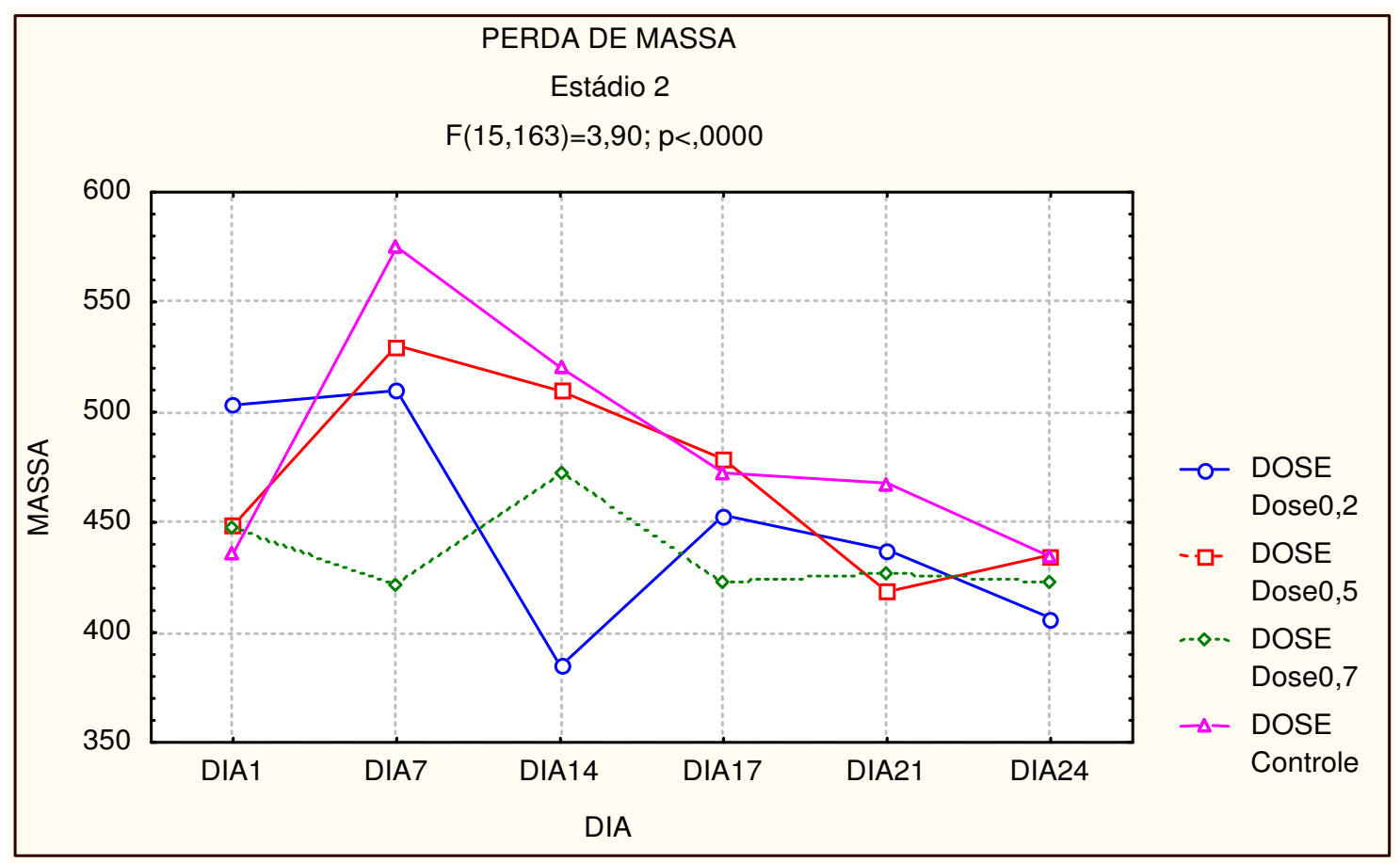

Gráfico 5 -Dias X Doses - Perda de Massa - Estádio 2

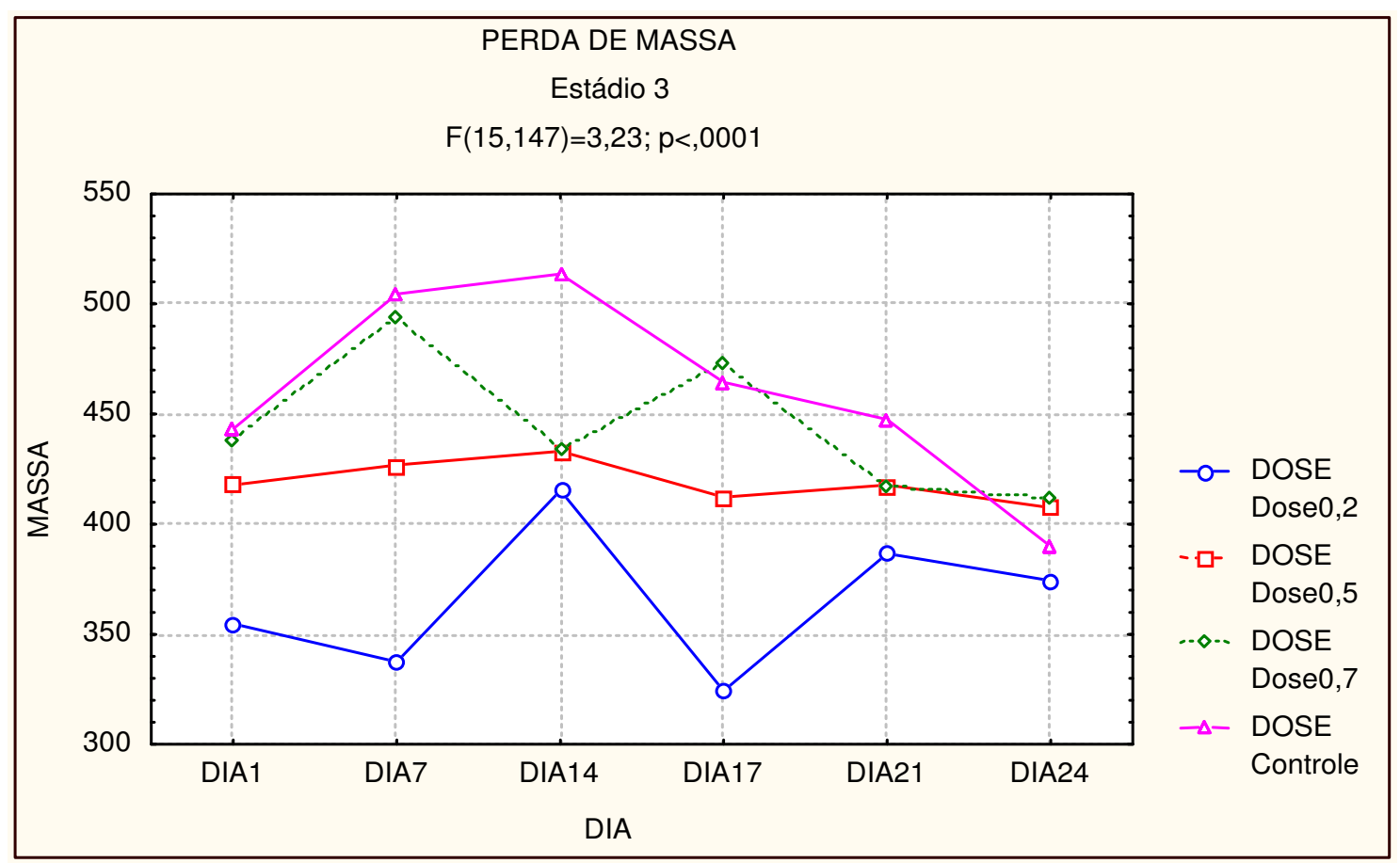

Gráfico 6 -Dias X Doses - Perda de Massa - Estádio 3 


\subsection{Textura}

\section{- Estádio 2}

Com o Duncan Test, Tabela 10 constatou-se que entre os dias 21 e 24 não houve diferença estatística entre as amostras.

No Gráfico 7, observa-se que a textura variou de maneira constante para as amostras.

Considerando o Dia 1 como ponto inicial de partida, percebe-se que independentemente da dose, a polpa da fruta perde gradativamente sua textura, observação também comprovada por Bleinroth, 1994.

- Estádio 3

Para as frutas no estádio 3, não há diferença significativa entre as amostras concentrou-se no último dia de análise (Tabela 11).

Após análise do Gráfico 8, observa-se que, neste estádio, a radiação gamma não interiu na variação de textura, pois o decaimento da textura da polpa foi praticamente constante para todas as amostras. 
Tabela 10 - Duncan Test - Estádio 2

\begin{tabular}{llr}
\hline \multicolumn{2}{c}{ TEXTURA (kgf) } \\
\hline Dia & Dose & $\begin{array}{c}\text { Média e Desvio } \\
\text { Padrão }\end{array}$ \\
\hline DIA 0 & Controle & $11,30^{\text {efgh }} \pm 0,53$ \\
\hline DIA 1 & Controle & $11,78^{\mathrm{hi}} \pm 0,84$ \\
DIA 1 & Dose 0,2 & $12,06^{\mathrm{i}} \pm 1,22$ \\
DIA 1 & Dose 0,5 & $11,61^{\text {ghi }} \pm 2,21$ \\
DIA 1 & Dose 0,75 & $11,13^{\text {fgh }} \pm 0,40$ \\
\hline DIA 7 & Controle & $9,56^{\text {efg }} \pm 3,41$ \\
DIA 7 & Dose 0,2 & $9,40^{\mathrm{ef}} \pm 1,81$ \\
DIA 7 & Dose 0,5 & $8,01^{\mathrm{e}^{\mathrm{e}}} \pm 2,96$ \\
DIA 7 & Dose 0,75 & $10,90^{\text {efgh }} \pm 2,81$ \\
\hline DIA 14 & Controle & $9,11^{\mathrm{ef}} \pm 3,28$ \\
DIA 14 & Dose 0,2 & $9,95^{\mathrm{efghi}} \pm 3,22$ \\
DIA 14 & Dose 0,5 & $6,04^{\mathrm{d}} \pm 3,00$ \\
DIA 14 & Dose 0,75 & $4,75^{\mathrm{cd}} \pm 2,30$ \\
\hline DIA 17 & Controle & $2,58^{\mathrm{ab}} \pm 0,60$ \\
DIA 17 & Dose 0,2 & $4,94^{\mathrm{cd}} \pm 2,72$ \\
DIA 17 & Dose 0,5 & $2,43^{\mathrm{ab}} \pm 0,82$ \\
DIA 17 & Dose 0,75 & $3,30^{\mathrm{bc}} \pm 1,47$ \\
\hline DIA 21 & Controle & $1,67^{\mathrm{ab}} \pm 0,29$ \\
DIA 21 & Dose 0,2 & $2,06^{\mathrm{ab}} \pm 0,47$ \\
DIA 21 & Dose 0,5 & $1,80^{\mathrm{ab}} \pm 0,33$ \\
DIA 21 & Dose 0,75 & $1,82^{\mathrm{ab}} \pm 0,91$ \\
\hline DIA 24 & Controle & $1,58^{\mathrm{ab}} \pm 0,29$ \\
DIA 24 & Dose 0,2 & $1,56^{\mathrm{ab}} \pm 0,40$ \\
DIA 24 & Dose 0,5 & $1,52^{\mathrm{ab}} \pm 0,15$ \\
DIA 24 & Dose 0,75 & $2,02^{\mathrm{ab}} \pm 0,10$ \\
\hline & &
\end{tabular}

Tabela 11 - Duncan Test - Estádio 3

\begin{tabular}{|c|c|c|}
\hline \multicolumn{3}{|c|}{ TEXTURA (Kgf) } \\
\hline Dia & Dose & $\begin{array}{c}\text { Médio e Desvio } \\
\text { Padrão }\end{array}$ \\
\hline DIA 0 & Controle & $5,10^{\text {efgh }} \pm 2,95$ \\
\hline DIA 1 & Controle & $5,10^{\text {efgh }} \pm 2,95$ \\
\hline DIA 1 & Dose 0,2 & $6,24^{\mathrm{fg}} \pm 4,17$ \\
\hline DIA 1 & Dose 0,5 & $6,07^{f g} \pm 3,89$ \\
\hline DIA 1 & Dose 0,75 & $8,78^{h} \pm 4,15$ \\
\hline DIA 7 & Controle & $5,30^{\mathrm{fgh}} \pm 3,24$ \\
\hline DIA 7 & Dose 0,2 & $5,28^{f g h} \pm 3,96$ \\
\hline DIA 7 & Dose 0,5 & $2,87^{\text {bcdef }} \pm 1,39$ \\
\hline DIA 7 & Dose 0,75 & $4,76^{\text {defgh }} \pm 3,65$ \\
\hline DIA 14 & Controle & $3,78^{\text {cdefg }_{ \pm}} 1,90$ \\
\hline DIA 14 & Dose 0,2 & $3,05^{\text {cdef }} \pm 1,18$ \\
\hline DIA 14 & Dose 0,5 & $2,67^{\text {abcdef }} \pm 1,93$ \\
\hline DIA 14 & Dose 0,75 & $3,66^{\text {cdefg }_{ \pm}} 1,53$ \\
\hline DIA 17 & Controle & $2,63^{\mathrm{abcd}} \pm 0,95$ \\
\hline DIA 17 & Dose 0,2 & $2,93^{\mathrm{abcd}} \pm 0,65$ \\
\hline DIA 17 & Dose 0,5 & $2,48^{\mathrm{abc}} \pm 0,55$ \\
\hline DIA 17 & Dose 0,75 & $3,48^{\mathrm{abcd}} \pm 0,51$ \\
\hline DIA 21 & Controle & $2,73^{\text {abcde }} \pm 0,73$ \\
\hline DIA 21 & Dose 0,2 & $2,93^{\mathrm{abcd}} \pm 0,90$ \\
\hline DIA 21 & Dose 0,5 & $2,80^{\mathrm{abcde}} \pm 0,77$ \\
\hline DIA 21 & Dose 0,75 & $3,30^{\mathrm{abcd}} \pm 0,69$ \\
\hline DIA 24 & Controle & $1,89^{a b c} \pm 0,16$ \\
\hline DIA 24 & Dose 0,2 & $2,63^{a b c} \pm 0,85$ \\
\hline DIA 24 & Dose 0,5 & $2,53^{a b c} \pm 0,73$ \\
\hline DIA 24 & Dose 0,75 & $2,63^{a b c} \pm 0,62$ \\
\hline
\end{tabular}

Obs.: Letras iguais indicam que não houve diferença significativa entre as amostras. 


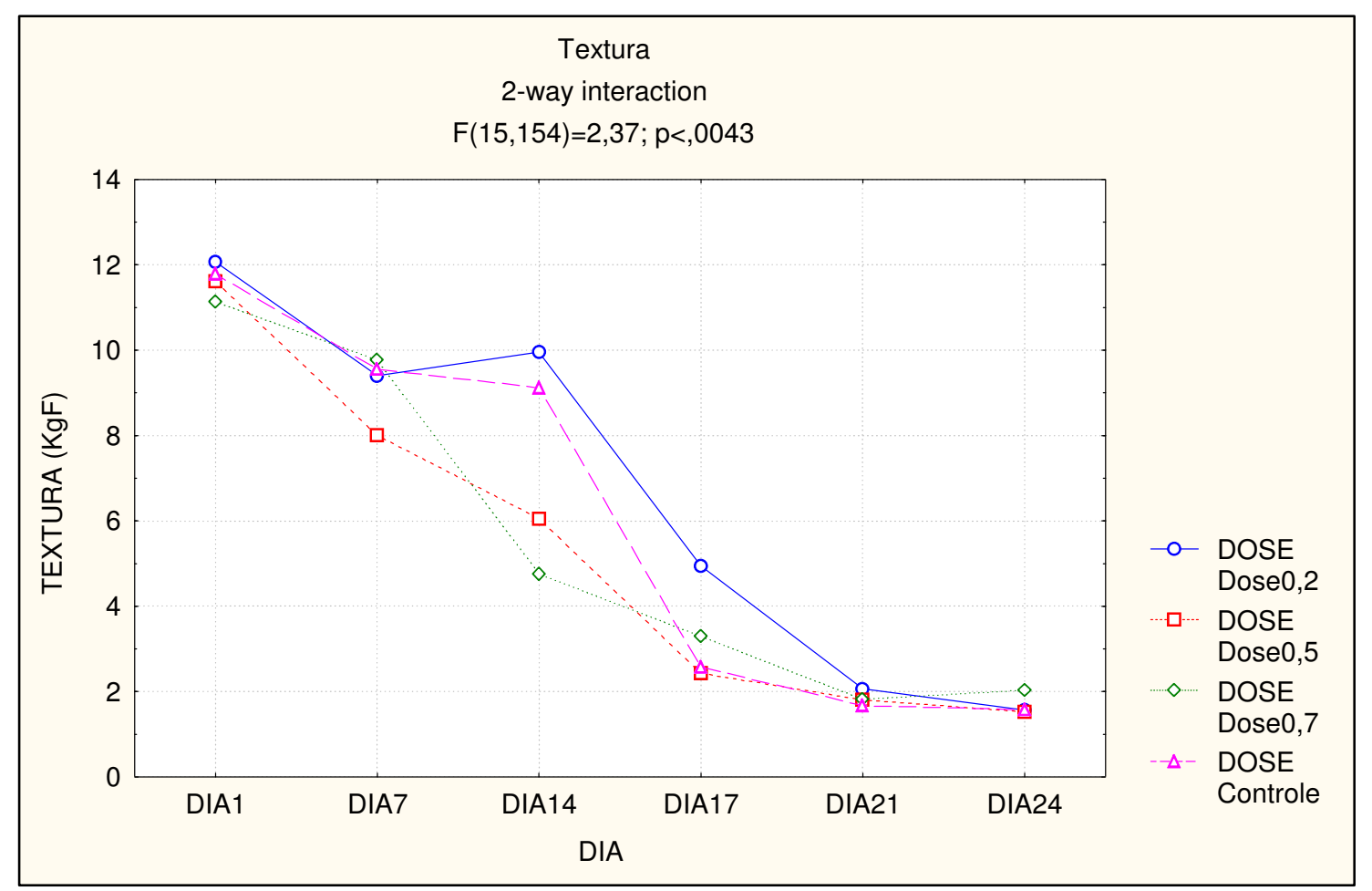

Gráfico 7 -Dias X Doses - Textura - Estádio 2

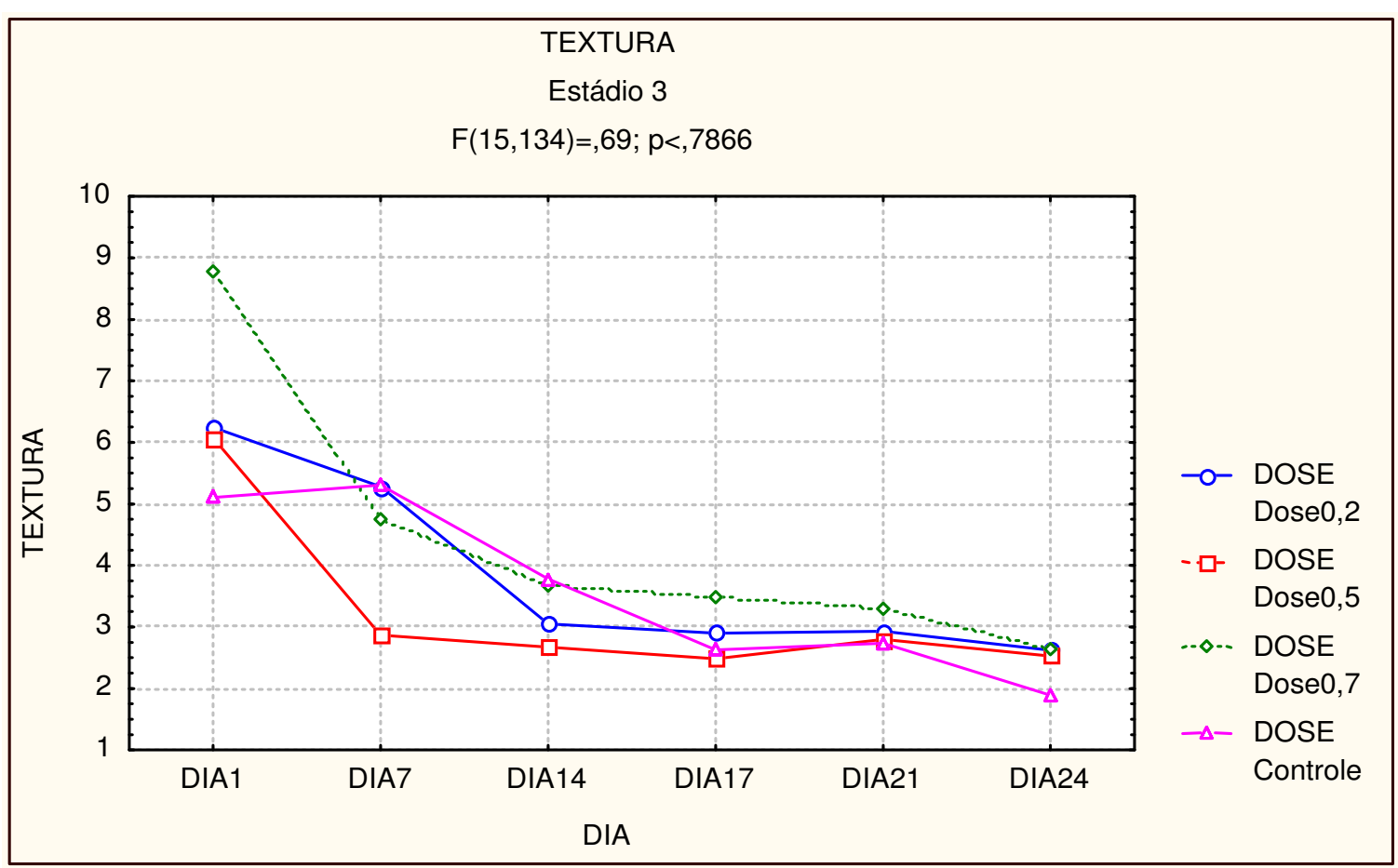

Gráfico 8 -Dias X Doses - Textura - Estádio 3 


\subsubsection{6. $\mathrm{pH}$}

\section{- Estádio 2}

Analisando separadamente cada dia de análise, pode-se dizer que no dia 14 não houve diferença significativa entre as amostras irradiadas. No dia 17, a diferença esteve entre o controle e a dose 0,5kGy. No dia 24, não houve gradiente entre as doses 0,2 e 0,5kGy (Tabela 12).

Para um bom resultado de $\mathrm{pH}$, espera-se que seja o mais baixo possível. Assim, graficamente, Gráfico 9, observa-se que a radiação nas doses 0,75 e 0,5kGy influenciaram para um resultado mais satisfatório.

\section{- Estádio 3}

Estatisticamente, no dia 1 não houve gradiente estatístico entre a amostra controle e doses 0,2 e 0,5. Nos dias 14 e 17, isto ocorreu para as amostra 14 e 17. Já, no dia 21 , entre as três doses (Tabela 13).

De acordo com o Gráfico 10, no dia 24, os resultados mais satisfatórios de $\mathrm{pH}$ foram para as mangas tratadas com as dosagens 0,75 e 0,2kGy, sucessivamente. 
Tabela 12 - Duncan Test - Estádio 2

\begin{tabular}{|c|c|c|}
\hline \multicolumn{3}{|c|}{$\mathrm{pH}$} \\
\hline Dia & Dose & $\begin{array}{c}\text { Média e Desvio } \\
\text { Padrão }\end{array}$ \\
\hline DIA 0 & Controle & $3,41^{a b c} \pm 1,39$ \\
\hline DIA 1 & Controle & $3,82^{\mathrm{abcde}} \pm 0,16$ \\
\hline DIA 1 & Dose 0,2 & $3,64^{\mathrm{abc}} \pm 0,16$ \\
\hline DIA 1 & Dose 0,5 & $3,84^{\mathrm{abcde}} \pm 0,24$ \\
\hline DIA 1 & Dose 0,75 & $3,64^{\mathrm{abc}} \pm 0,26$ \\
\hline DIA 7 & Controle & $3,61^{a b c} \pm 0,27$ \\
\hline DIA 7 & Dose 0,2 & $3,36^{a b} \pm 0,20$ \\
\hline DIA 7 & Dose 0,5 & $3,71^{\mathrm{abcd}} \pm 0,33$ \\
\hline DIA 7 & Dose 0,75 & $3,79^{\mathrm{abcde}} \pm 0,16$ \\
\hline DIA 14 & Controle & $3,74^{\mathrm{abcd}} \pm 0,15$ \\
\hline DIA 14 & Dose 0,2 & $3,64^{\mathrm{abc}} \pm 0,17$ \\
\hline DIA 14 & Dose 0,5 & $3,51^{a b c} \pm 0,11$ \\
\hline DIA 14 & Dose 0,75 & $3,55^{\mathrm{abc}} \pm 0,23$ \\
\hline DIA 17 & Controle & $3,74^{\mathrm{abcd}} \pm 0,21$ \\
\hline DIA 17 & Dose 0,2 & $3,53^{a b c} \pm 0,20$ \\
\hline DIA 17 & Dose 0,5 & $3,30^{\mathrm{ab}} \pm 1,36$ \\
\hline DIA 17 & Dose 0,75 & $3,54^{a b c} \pm 0,28$ \\
\hline DIA 21 & Controle & $4,48^{\text {def }} \pm 0,25$ \\
\hline DIA 21 & Dose 0,2 & $4,24^{\text {cdef }} \pm 0,20$ \\
\hline DIA 21 & Dose 0,5 & $4,04^{\mathrm{abcde}} \pm 0,32$ \\
\hline DIA 21 & Dose 0,75 & $3,08^{a} \pm 1,92$ \\
\hline DIA 24 & Controle & $4,76^{\dagger} \pm 0,17$ \\
\hline DIA 24 & Dose 0,2 & $4,07^{\text {bcdef }} \pm 1,66$ \\
\hline DIA 24 & Dose 0,5 & $3,98^{\text {bcdef }} \pm 1,61$ \\
\hline DIA 24 & Dose 0,75 & $4,58^{\mathrm{ef}} \pm 0,10$ \\
\hline
\end{tabular}

Tabela 13 - Duncan Test - Estádio 3

\begin{tabular}{llr}
\hline & \multicolumn{2}{c}{ pH } \\
\hline Dia & Dose & $\begin{array}{c}\text { Média e Desvio } \\
\text { Padrão }\end{array}$ \\
\hline DIA 0 & Controle & $3,38^{\mathrm{bcd}} \pm 0,28$ \\
\hline DIA 1 & Controle & $3,38^{\mathrm{bcd}} \pm 0,28$ \\
DIA 1 & Dose 0,2 & $3,30^{\mathrm{bcd}} \pm 0,47$ \\
DIA 1 & Dose 0,5 & $3,16^{\mathrm{bcd}} \pm 0,35$ \\
DIA 1 & Dose 0,75 & $2,40^{\mathrm{abc}} \pm 1,51$ \\
\hline DIA 7 & Controle & $3,72^{\mathrm{cd}} \pm 0,29$ \\
DIA 7 & Dose 0,2 & $3,40^{\mathrm{bcd}} \pm 0,17$ \\
DIA 7 & Dose 0,5 & $3,79^{\mathrm{cd}} \pm 0,49$ \\
DIA 7 & Dose 0,75 & $3,66^{\mathrm{bcd}} \pm 0,46$ \\
\hline DIA 14 & Controle & $3,64^{\mathrm{bcd}} \pm 0,37$ \\
DIA 14 & Dose 0,2 & $3,65^{\mathrm{bcd}} \pm 0,30$ \\
DIA 14 & Dose 0,5 & $4,09^{\mathrm{d}} \pm 0,66$ \\
DIA 14 & Dose 0,75 & $3,71^{\mathrm{cd}} \pm 0,42$ \\
\hline DIA 17 & Controle & $3,13^{\mathrm{bcd}} \pm 1,97$ \\
DIA 17 & Dose 0,2 & $3,39^{\mathrm{bcd}} \pm 1,50$ \\
DIA 17 & Dose 0,5 & $4,48^{\mathrm{d}} \pm 0,36$ \\
DIA 17 & Dose 0,75 & $3,80^{\mathrm{cd}} \pm 0,39$ \\
\hline DIA 21 & Controle & $3,84^{\mathrm{cd}} \pm 1,57$ \\
DIA 21 & Dose 0,2 & $3,11^{\mathrm{bcd}} \pm 1,96$ \\
DIA 21 & Dose 0,5 & $3,28^{\mathrm{bcd}} \pm 2,05$ \\
DIA 21 & Dose 0,75 & $3,02^{\mathrm{bcd}} \pm 1,94$ \\
\hline DIA 24 & Controle & $3,32^{\mathrm{bcd}} \pm 2,05$ \\
DIA 24 & Dose 0,2 & $4,23^{\mathrm{d}} \pm 0,47$ \\
DIA 24 & Dose 0,5 & $2,25^{\mathrm{ab}} \pm 2,41$ \\
DIA 24 & Dose 0,75 & $1,50^{\mathrm{a}} \pm 2,10$ \\
\hline & & \\
\hline & &
\end{tabular}

Obs.: Letras iguais indicam que não houve diferença significativa entre as amostras. 


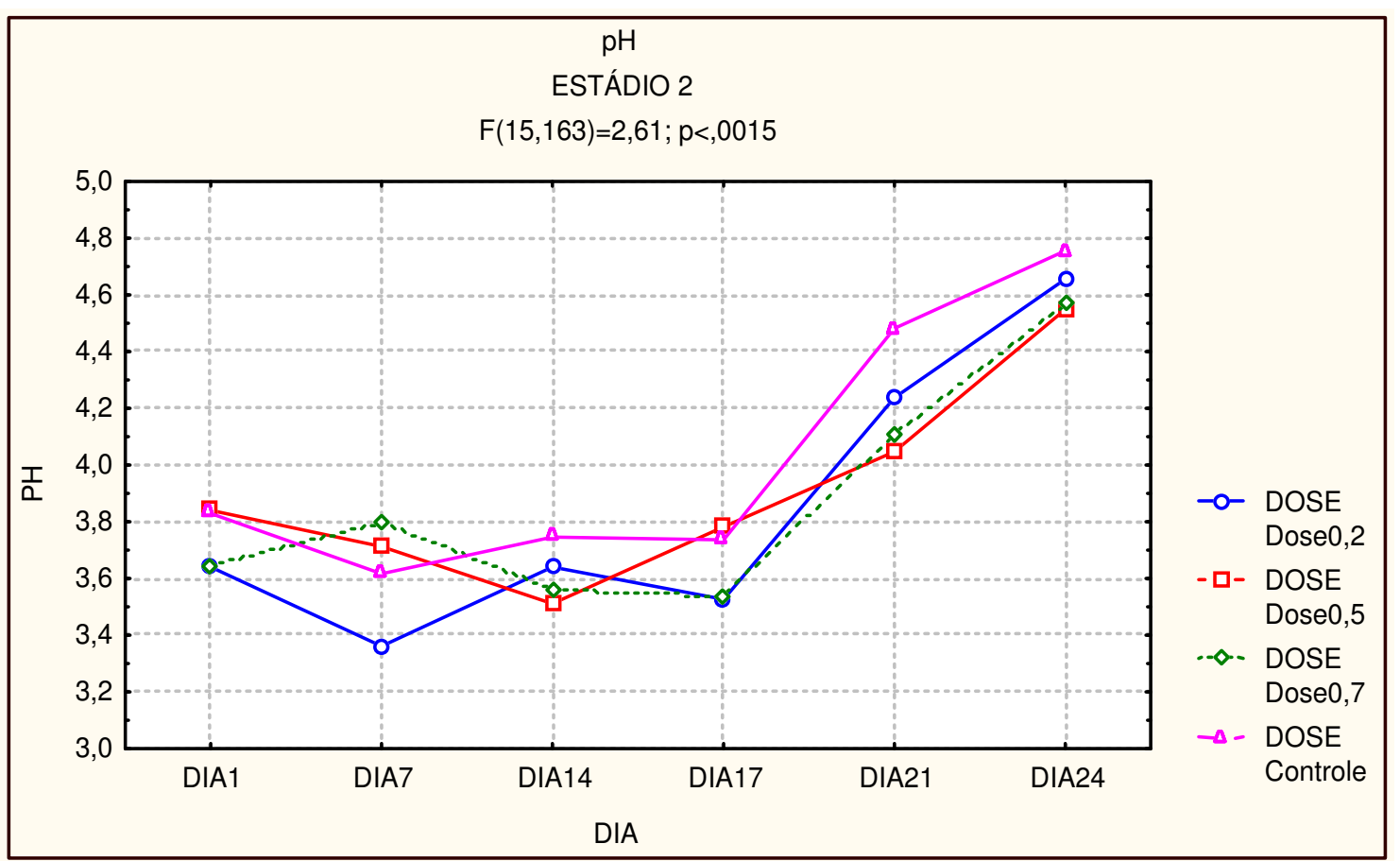

Gráfico 9 -Dias X Doses - pH - Estádio 2

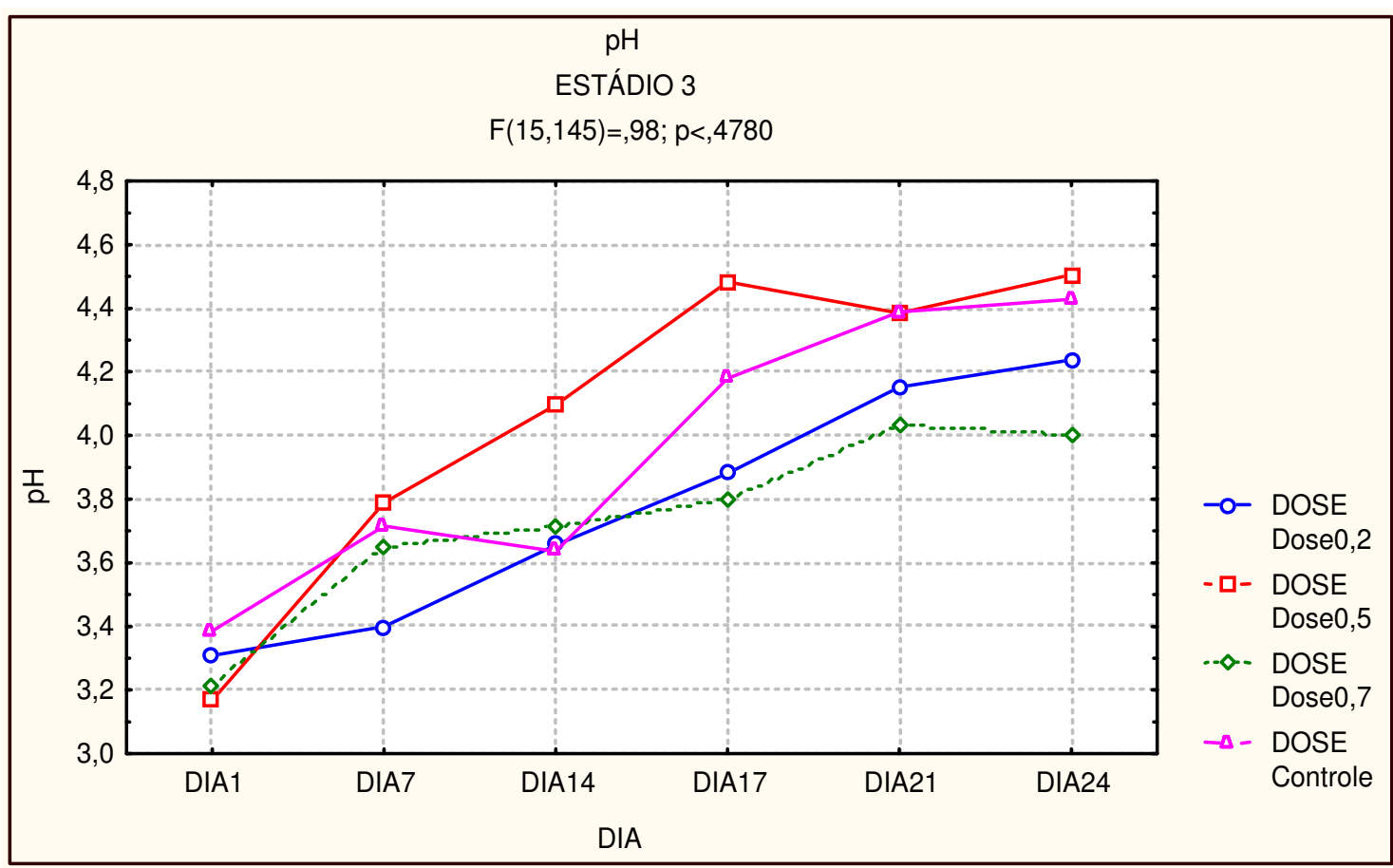

Gráfico 10 - Dias X Doses - pH - Estádio 3 


\subsection{Acidez - \% Ácido Cítrico}

- Estádio 2

Com a aplicação do Duncan Test, constata-se que no dia 7 não houve diferença estatística entre as amostras tratadas por irradiação. No dia 21 , sucedeu-se entre o controle e dose 0,5kGy, e dose 0,2 e 0,75kGy. Porém no dia 24, não houve gradiente entre os quatro grupos (Tabela 14).

Graficamente, no estádio 2 a irradiação não resultou em diferença significativa final, ou seja, no dia 24 a acidez foi praticamente igual para os quatro grupos de mangas estudadas, independente do caminho percorrido (Gráfico 11).

De acordo com Manica et al., 2001, o processo do amadurecimento reduz a acidez e aumenta a quantidade de açúcares solúveis (frutose).

\section{- Estádio 3}

Para o último dia de análise, não houve diferença estatística entre 0 controle, doses 0,5 e 0,75kGy, assim como no dia 21 não correu para a dose 0,2 e 0,75kGy; controle e 0,5kGy (Tabela 15).

Pelo Gráfico 12, não ocorreu diferença para a acidez final. 
Tabela 14 - Duncan Test - Estádio 2

\begin{tabular}{llr}
\hline \multicolumn{2}{c}{ ACIDEZ (\%) } \\
\hline Dia & Dose & $\begin{array}{c}\text { Média e Desvio } \\
\text { Padrão }\end{array}$ \\
\hline DIA 0 & Controle & $0,82^{\text {hi }} \pm 0,35$ \\
\hline DIA 1 & Controle & $0,83^{\text {hi }} \pm 0,16$ \\
DIA 1 & Dose 0,2 & $0,61^{\text {efg }} \pm 0,27$ \\
DIA 1 & Dose 0,5 & $0,73^{\text {ghi }} \pm 0,10$ \\
DIA 1 & Dose 0,75 & $0,86^{\mathrm{I}} \pm 0,12$ \\
\hline DIA 7 & Controle & $0,69^{\text {fgh }} \pm 0,14$ \\
DIA 7 & Dose 0,2 & $0,53^{\text {cde }} \pm 0,11$ \\
DIA 7 & Dose 0,5 & $0,52^{\text {cde }} \pm 0,11$ \\
DIA 7 & Dose 0,75 & $0,63^{\text {efg }} \pm 0,08$ \\
\hline DIA 14 & Controle & $0,74^{\text {ghi }} \pm 0,13$ \\
DIA 14 & Dose 0,2 & $0,69^{\text {fgh }} \pm 0,13$ \\
DIA 14 & Dose 0,5 & $0,67^{\text {efg }} \pm 0,09$ \\
DIA 14 & Dose 0,75 & $0,55^{\text {def }} \pm 0,27$ \\
\hline DIA 17 & Controle & $0,55^{\text {cd }} \pm 0,10$ \\
DIA 17 & Dose 0,2 & $0,62^{\text {efg }} \pm 0,11$ \\
DIA 17 & Dose 0,5 & $0,39^{\mathrm{c}} \pm 0,19$ \\
DIA 17 & Dose 0,75 & $0,52^{\text {cde }} \pm 0,09$ \\
\hline DIA 21 & Controle & $0,24^{\mathrm{b}} \pm 0,06$ \\
DIA 21 & Dose 0,2 & $0,27^{\text {ab }} \pm 0,06$ \\
DIA 21 & Dose 0,5 & $0,27^{\mathrm{a}} \pm 0,06$ \\
DIA 21 & Dose 0,75 & $0,24^{\text {ab }} \pm 0,03$ \\
\hline DIA 24 & Controle & $0,14^{\text {ab }} \pm 0,03$ \\
DIA 24 & Dose 0,2 & $0,14^{\text {ab }} \pm 0,03$ \\
DIA 24 & Dose 0,5 & $0,15^{\text {ab }} \pm 0,02$ \\
DIA 24 & Dose 0,75 & $0,17^{\text {ab }} \pm 0,02$ \\
\hline
\end{tabular}

Tabela 15 - Duncan Test - Estádio 3

\begin{tabular}{|c|c|c|}
\hline \multicolumn{3}{|c|}{ ACIDEZ (\%) } \\
\hline Dia & Dose & $\begin{array}{l}\text { Média e Desvio } \\
\text { Padrão }\end{array}$ \\
\hline DIA 0 & Controle & $0,47^{\text {ghil }} \pm 0,12$ \\
\hline DIA 1 & Controle & $0,47^{\text {ghijl }} \pm 0,12$ \\
\hline DIA 1 & Dose 0,2 & $0,57^{\mathrm{ij} \mathrm{il}} \pm 0,18$ \\
\hline DIA 1 & Dose 0,5 & $0,66^{\prime} \pm 0,25$ \\
\hline DIA 1 & Dose 0,75 & $0,58^{\mathrm{i}} \pm 0,42$ \\
\hline DIA 7 & Controle & $0,51^{\text {hijl }} \pm 0,18$ \\
\hline DIA 7 & Dose 0,2 & $0,4+8^{\text {ghill }} \pm 0,12$ \\
\hline DIA 7 & Dose 0,5 & $0,27^{\text {cefg }_{ \pm}} 0,16$ \\
\hline DIA 7 & Dose 0,75 & $0,42^{\text {fghij }} \pm 0,20$ \\
\hline DIA 14 & Controle & $0,37^{\text {efgh }} \pm 0,19$ \\
\hline DIA 14 & Dose 0,2 & $0,33^{\text {defg }_{ \pm}} 0,18$ \\
\hline DIA 14 & Dose 0,5 & $0,17^{\mathrm{abcd}} \pm 0,09$ \\
\hline DIA 14 & Dose 0,75 & $0,39^{\text {efghi }} \pm 0,15$ \\
\hline DIA 17 & Controle & $0,23^{\mathrm{bcde}} \pm 0,18$ \\
\hline DIA 17 & Dose 0,2 & $0,18^{b c d} \pm 0,11$ \\
\hline DIA 17 & Dose 0,5 & $0,12^{\mathrm{abc}} \pm 0,10$ \\
\hline DIA 17 & Dose 0,75 & $0,33^{\text {defg }_{ \pm}} 0,22$ \\
\hline DIA 21 & Controle & $0,11^{\mathrm{abc}} \pm 0,05$ \\
\hline DIA 21 & Dose 0,2 & $0,09^{\mathrm{ab}} \pm 0,08$ \\
\hline DIA 21 & Dose 0,5 & $0,10^{a b c} \pm 0,07$ \\
\hline DIA 21 & Dose 0,75 & $0,08^{a b} \pm 0,14$ \\
\hline DIA 24 & Controle & $0,08^{a b} \pm 0,08$ \\
\hline DIA 24 & Dose 0,2 & $0,15^{a b c} \pm 0,05$ \\
\hline DIA 24 & Dose 0,5 & $0,06^{\mathrm{ab}} \pm 0,08$ \\
\hline DIA 24 & Dose 0,75 & $0,05^{\mathrm{ab}} \pm 0,08$ \\
\hline
\end{tabular}

Obs.: Letras iguais indicam que não houve diferença significativa entre as amostras. 


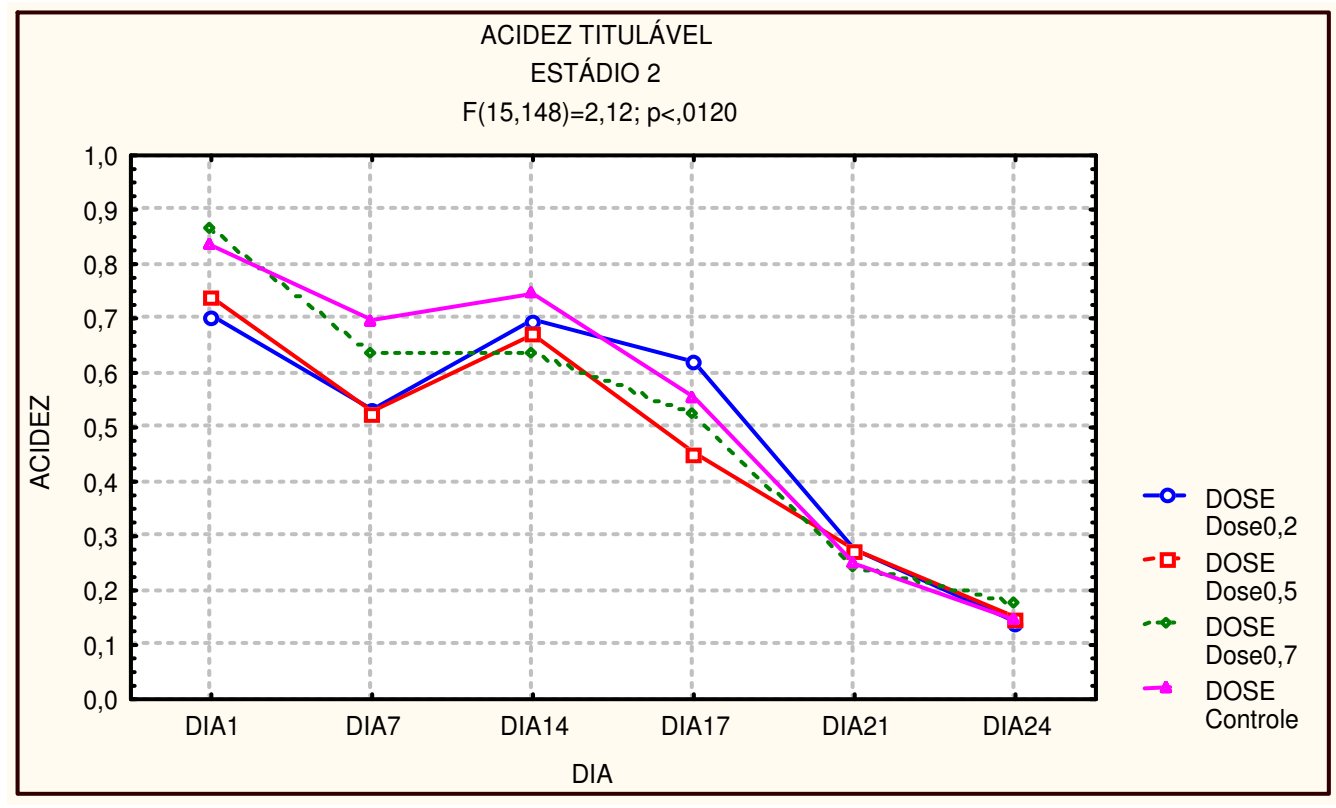

Gráfico 11 -Dias X Doses - Acidez - Estádio 2

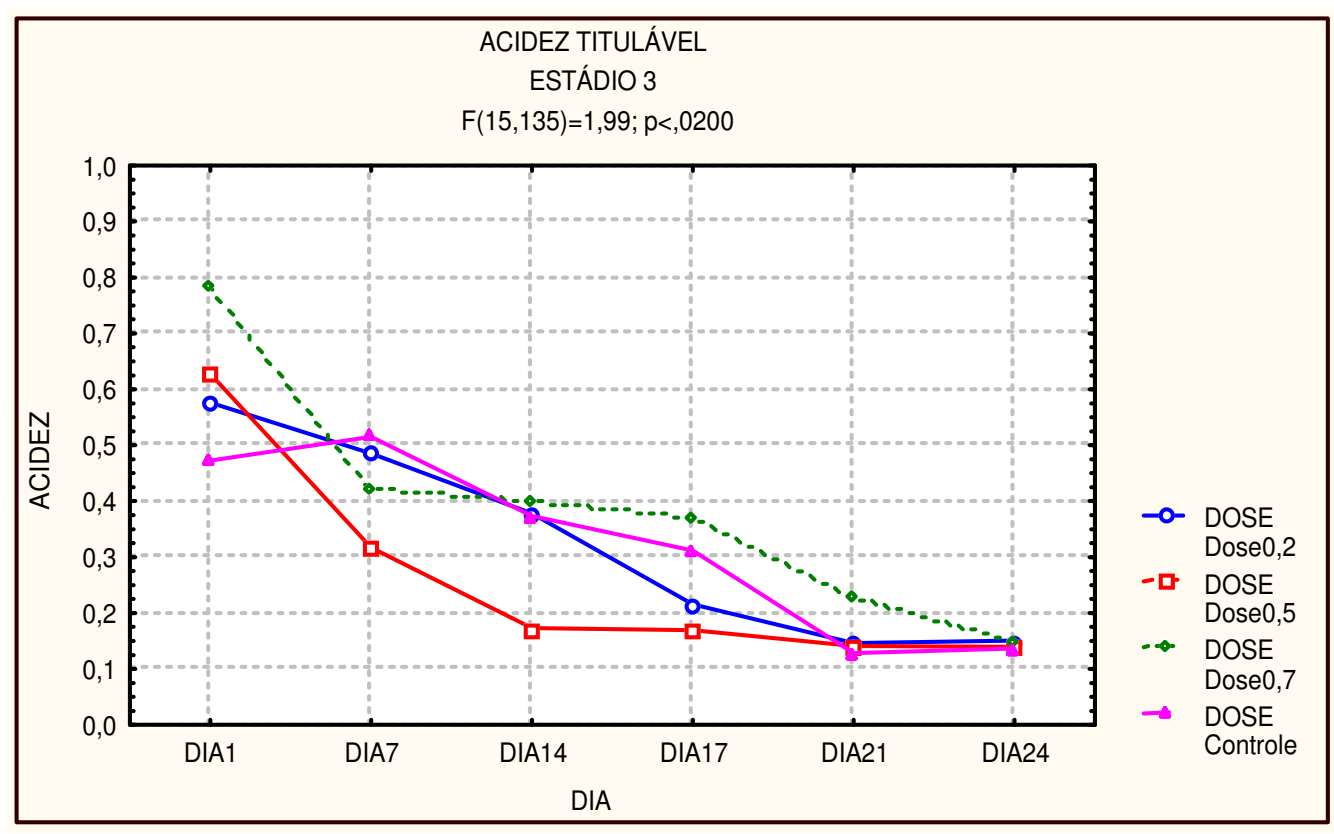

Gráfico 12 - Dias X Doses - Acidez - Estádio 3 


\subsection{Sólidos Solúveis}

\section{- Estádio 2}

Nas análises de sólidos solúveis, pode ser dito que para cada dia, houve diferenças estatísticas entre as amostras (Tabela 16).

Entende-se que o resultado satisfatório para sólidos solúveis, neste cenário, é o menor valor encontrado, o que representa uma maturação mais lenta da fruta.

Silva et al., 2003, concluiu que durante o amadurecimento o amido é hidrolizado em açúcares, aumentando a quantidade de sólidos totais.

Assim, diante do Gráfico 13, as mangas tratadas a 0,75kGy apresentam melhor resultado.

\section{- Estádio 3}

Os resultados de Duncan Test, para a análise de sólidos solúveis no estádio 3 revelam que há diferença estatística entre as amostras para cada dia isolado (Tabela 17).

O Gráfico 14 revela que a dose 0,2kGy apresentou menor valor no dia 24, entretanto todas as amostras indicaram grande variação entre os dias das análises. 
Tabela 16 - Duncan Test - Estádio 2

\begin{tabular}{|c|c|c|}
\hline \multicolumn{3}{|c|}{ OBRIX } \\
\hline Dia & Dose & $\begin{array}{c}\text { Média e Desvio } \\
\text { Padrão }\end{array}$ \\
\hline DIA 0 & Controle & $5,76^{a} \pm 2,38$ \\
\hline DIA 1 & Controle & $6,95^{\mathrm{abc}} \pm 0,59$ \\
\hline DIA 1 & Dose 0,2 & $7,62^{\mathrm{abcd}} \pm 3,38$ \\
\hline DIA 1 & Dose 0,5 & $8,15^{\mathrm{abcde}} \pm 0,97$ \\
\hline DIA 1 & Dose 0,75 & $6,88^{\mathrm{abc}} \pm 1,58$ \\
\hline DIA 7 & Controle & $9,65^{\text {bcdefg }_{ \pm}} 1,47$ \\
\hline DIA 7 & Dose 0,2 & $10,13^{\text {bcdefg }_{ \pm}} 1,70$ \\
\hline DIA 7 & Dose 0,5 & $9,67^{\text {bcdefg }_{ \pm}} 1,43$ \\
\hline DIA 7 & Dose 0,75 & $8,85^{\mathrm{abcde}} \pm 1,02$ \\
\hline DIA 14 & Controle & $11,95^{\mathrm{efg}} \pm 1,67$ \\
\hline DIA 14 & Dose 0,2 & $13,10^{9} \pm 0,82$ \\
\hline DIA 14 & Dose 0,5 & $12,77^{\mathrm{fg}} \pm 1,03$ \\
\hline DIA 14 & Dose 0,75 & $13,04^{g} \pm 1,06$ \\
\hline DIA 17 & Controle & $9,20^{\text {abcdef }} \pm 5,79$ \\
\hline DIA 17 & Dose 0,2 & $11,27^{\text {defg }_{ \pm}} 1,06$ \\
\hline DIA 17 & Dose 0,5 & $9,99^{\text {bcdefg }} \pm 4,32$ \\
\hline DIA 17 & Dose 0,75 & $10,61^{\text {cdeff }_{ \pm}} 1,22$ \\
\hline DIA 21 & Controle & $11,62^{\text {efg }} \pm 0,97$ \\
\hline DIA 21 & Dose 0,2 & $6,32^{\mathrm{ab}} \pm 6,92$ \\
\hline DIA 21 & Dose 0,5 & $11,96^{\mathrm{efg}} \pm 1,29$ \\
\hline DIA 21 & Dose 0,75 & $7,48^{\mathrm{abcd}} \pm 6,20$ \\
\hline DIA 24 & Controle & $10,97^{\text {defg }_{ \pm}} 4,76$ \\
\hline DIA 24 & Dose 0,2 & $9,53^{\text {bcdefg }_{ \pm}} 6,01$ \\
\hline DIA 24 & Dose 0,5 & $9,28^{\text {abcdefg }_{ \pm}} 5,74$ \\
\hline DIA 24 & Dose 0,75 & $8,39^{\text {abcde }} \pm 3,77$ \\
\hline
\end{tabular}

Tabela 17 - Duncan Test - Estádio 3

\begin{tabular}{llr}
\hline \multicolumn{3}{c}{ oBRIX } \\
\hline Dia & Dose & $\begin{array}{c}\text { Média e Desvio } \\
\text { Padrão }\end{array}$ \\
\hline DIA 0 & Controle & $10,14^{\text {ef }} \pm 0,96$ \\
\hline DIA 1 & Controle & $10,14^{\text {ef }} \pm 0,96$ \\
DIA 1 & Dose 0,2 & $9,82^{\text {ef }} \pm 2,07$ \\
DIA 1 & Dose 0,5 & $8,99^{\text {def }} \pm 1,51$ \\
DIA 1 & Dose 0,75 & $7,01^{\text {bcdef }} \pm 4,43$ \\
\hline DIA 7 & Controle & $8,56^{\text {cdef }} \pm 3,27$ \\
DIA 7 & Dose 0,2 & $10,68^{f} \pm 1,20$ \\
DIA 7 & Dose 0,5 & $9,47^{\text {cdef }} \pm 2,84$ \\
DIA 7 & Dose 0,75 & $9,71^{\text {ef }} \pm 2,69$ \\
\hline DIA 14 & Controle & $9,90^{\text {ef }} \pm 1,91$ \\
DIA 14 & Dose 0,2 & $9,41^{\text {cdef }} \pm 0,80$ \\
DIA 14 & Dose 0,5 & $10,18^{\text {ef }} \pm 1,34$ \\
DIA 14 & Dose 0,75 & $9,26^{\text {ef }} \pm 1,88$ \\
\hline DIA 17 & Controle & $7,16^{\text {bcdef }} \pm 4,51$ \\
DIA 17 & Dose 0,2 & $9,36^{\text {ef }} \pm 4,40$ \\
DIA 17 & Dose 0,5 & $7,78^{\text {cdef }} \pm 4$ \\
DIA 17 & Dose 0,75 & $7,38^{\text {bcdef }} \pm 4,65$ \\
\hline DIA 21 & Controle & $8,13^{\text {cdef }} \pm 3,43$ \\
DIA 21 & Dose 0,2 & $6,13^{\text {bcde }} \pm 5,11$ \\
DIA 21 & Dose 0,5 & $6,06^{\text {bcde }} \pm 5,03$ \\
DIA 21 & Dose 0,75 & $3,42^{\text {ab }} \pm 4,81$ \\
\hline DIA 24 & Controle & $4,94^{\text {bcd }} \pm 5,38$ \\
DIA 24 & Dose 0,2 & $8,22^{\text {cdef }} \pm 1,82$ \\
DIA 24 & Dose 0,5 & $5,03^{\text {bcd }} \pm 5,42$ \\
DIA 24 & Dose 0,75 & $6,03^{\text {bc }} \pm 5,28$ \\
\hline
\end{tabular}

Obs.: Letras iguais indicam que não houve diferença significativa entre as amostras. 


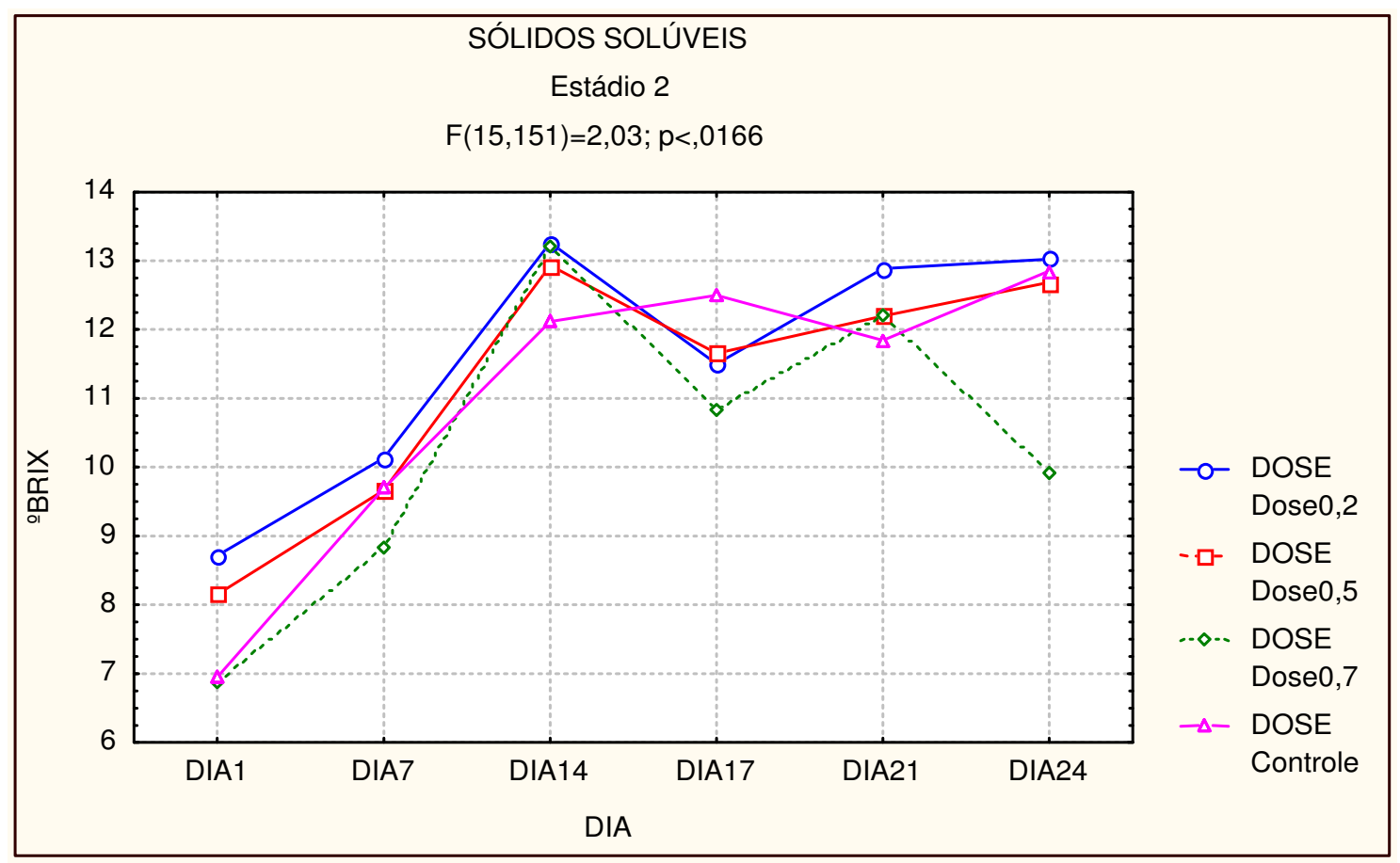

Gráfico 13 - Dias X Doses - Sólidos Solúveis - Estádio 2

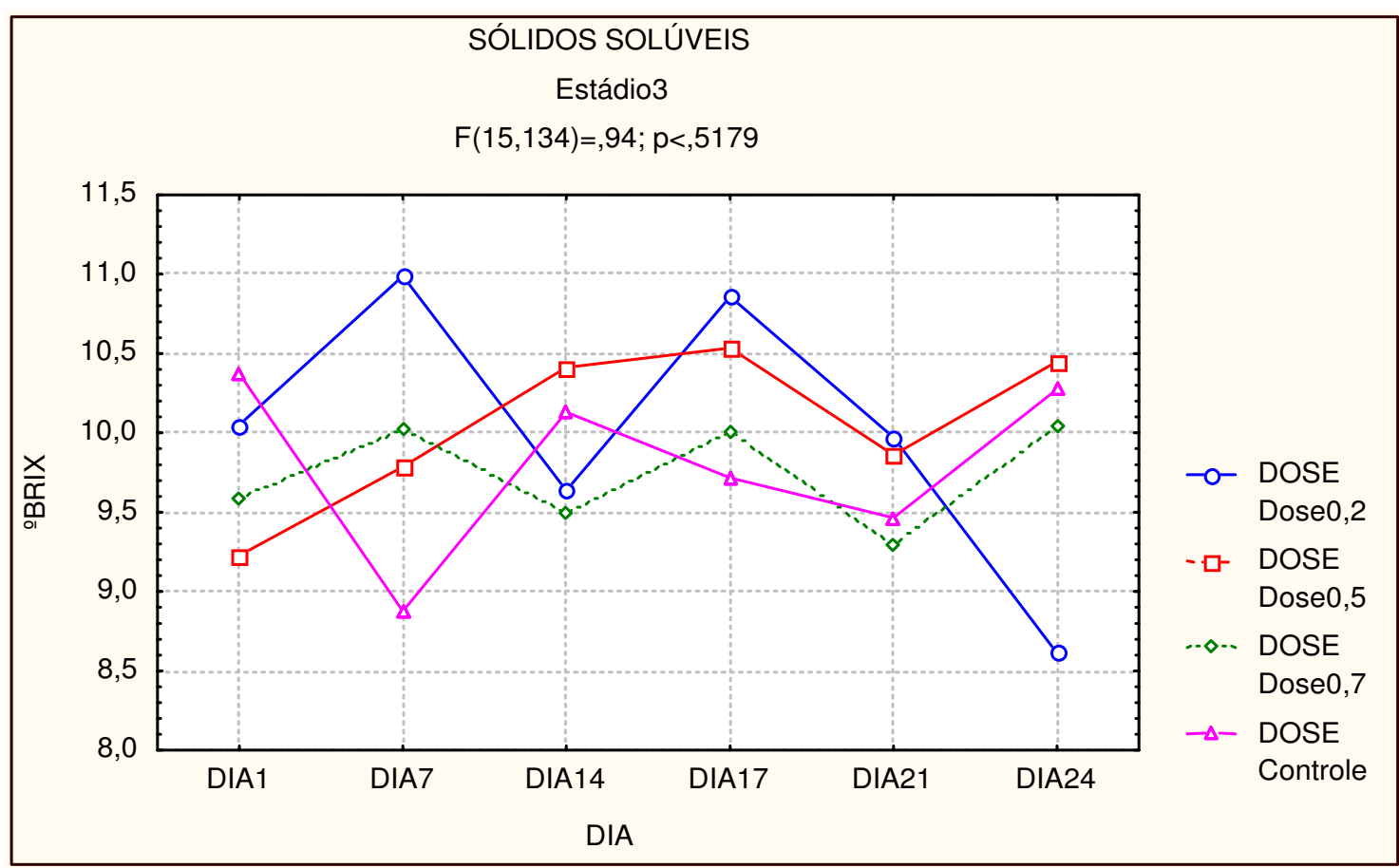

Gráfico 14 -Dias X Doses - Sólidos Solúveis - Estádio 3 


\subsubsection{Resultados do lote 20}

\subsubsection{Perda de Massa}

\section{- Estádio 2}

Para o lote 20, pode ser afirmado que não houve um dia de pesagem em que não ocorrido diferença estatística entre duas ou mais amostras (Tabela 18).

Ao estudarmos o gráfico abaixo (Gráfico 15), observa-se que a partir do dia 16 iniciou-se a perda de massa dos frutos. Entretanto, o controle apresentou uma maior queda em relação as frutas irradiadas.

Dentre os resultados, a menor oscilação de perda de massa sucedeu-se para a dose 0,2 kGy.

\section{- Estádio 3}

Para o estádio 3, diante do Tabela 19, houve diferenças estatísticas entre amostras.

Independentemente das doses de radiação, as mangas no estádio 3 apresentaram variações de quedas constantes e similares (Gráfico 16). Contudo, a perda de peso foi maior para a dose 0,75kGy. 
Tabela 18 - Duncan Test - Estádio 2

\begin{tabular}{|c|c|c|}
\hline \multicolumn{3}{|c|}{ PERDA DE MASSA } \\
\hline Dia & Dose & $\begin{array}{c}\text { Média e Desvio } \\
\text { Padrão }\end{array}$ \\
\hline DIA 1 & Controle & $405,56^{\text {abcde }} \pm 80,86$ \\
\hline DIA 1 & Dose 0,2 & $398,92^{\mathrm{abcde}} \pm 63,72$ \\
\hline DIA 1 & Dose 0,5 & $449,04^{e} \pm 48,77$ \\
\hline DIA 1 & Dose 0,75 & $432,14^{\mathrm{cde}} \pm 52,30$ \\
\hline DIA 4 & Controle & $404,29^{\text {abcde }} \pm 81,02$ \\
\hline DIA 4 & Dose 0,2 & $396,62^{\mathrm{abcde}} \pm 64,49$ \\
\hline DIA 4 & Dose 0,5 & $447,94^{\mathrm{abcde}} \pm 48,64$ \\
\hline DIA 4 & Dose 0,75 & $430,14^{\mathrm{e}} \pm 52,98$ \\
\hline DIA 8 & Controle & $404,90^{\mathrm{abcde}} \pm 81,08$ \\
\hline DIA 8 & Dose 0,2 & $397,46^{\text {abcde }} \pm 64,50$ \\
\hline DIA 8 & Dose 0,5 & $448,81^{e} \pm 48,64$ \\
\hline DIA 8 & Dose 0,75 & $431,61^{\mathrm{cde}} \pm 52,71$ \\
\hline DIA 12 & Controle & $403,01^{\mathrm{abcde}} \pm 80,83$ \\
\hline DIA 12 & Dose 0,2 & $395,92^{\mathrm{abcde}} \pm 64,38$ \\
\hline DIA 12 & Dose 0,5 & $445,43^{\mathrm{de}} \pm 48,66$ \\
\hline DIA 12 & Dose 0,75 & $429,73^{\mathrm{cde}} \pm 52,59$ \\
\hline DIA 16 & Controle & $400,34^{\mathrm{abcde}} \pm 80,55$ \\
\hline DIA 16 & Dose 0,2 & $394,42^{\mathrm{abcd}} \pm 64,28$ \\
\hline DIA 16 & Dose 0,5 & $444,87^{\mathrm{de}} \pm 48,14$ \\
\hline DIA 16 & Dose 0,75 & $426,99^{\text {bcde }} \pm 52,45$ \\
\hline DIA 20 & Controle & $387,23^{\mathrm{abc}} \pm 79,63$ \\
\hline DIA 20 & Dose 0,2 & $390,34^{\mathrm{abc}} \pm 66,31$ \\
\hline DIA 20 & Dose 0,5 & $446,32^{\mathrm{de}} \pm 48,68$ \\
\hline DIA 20 & Dose 0,75 & $417,32^{\text {bcde }} \pm 47,11$ \\
\hline DIA 24 & Controle & $374,79^{\mathrm{ab}} \pm 78,72$ \\
\hline DIA 24 & Dose 0,2 & $388,94^{\mathrm{abc}} \pm 67,99$ \\
\hline DIA 24 & Dose 0,5 & $432,89^{\mathrm{cde}} \pm 46,60$ \\
\hline DIA 24 & Dose 0,75 & $413,65^{\mathrm{bcde}} \pm 36,68$ \\
\hline DIA 28 & Controle & $357,58^{a} \pm 74,36$ \\
\hline DIA 28 & Dose 0,2 & $376,65^{\mathrm{ab}} \pm 55,06$ \\
\hline DIA 28 & Dose 0,5 & $422,22^{b c d e} \pm 48,33$ \\
\hline DIA 28 & Dose 0,75 & $403,15^{\text {abcde }} \pm 33,39$ \\
\hline
\end{tabular}

Tabela 19 - Duncan Test - Estádio 3

\begin{tabular}{llr}
\hline \multicolumn{2}{c}{ PERDA DE MASSA } \\
\hline Dia & Dose & \multicolumn{1}{c}{ Média e Desvio } \\
Padrão
\end{tabular}

Obs.: Letras iguais indicam que não houve diferença significativa entre as amostras. 
Gráfico 15 -Dias X Doses - Perda de Massa Lote 20 - Estádio 2

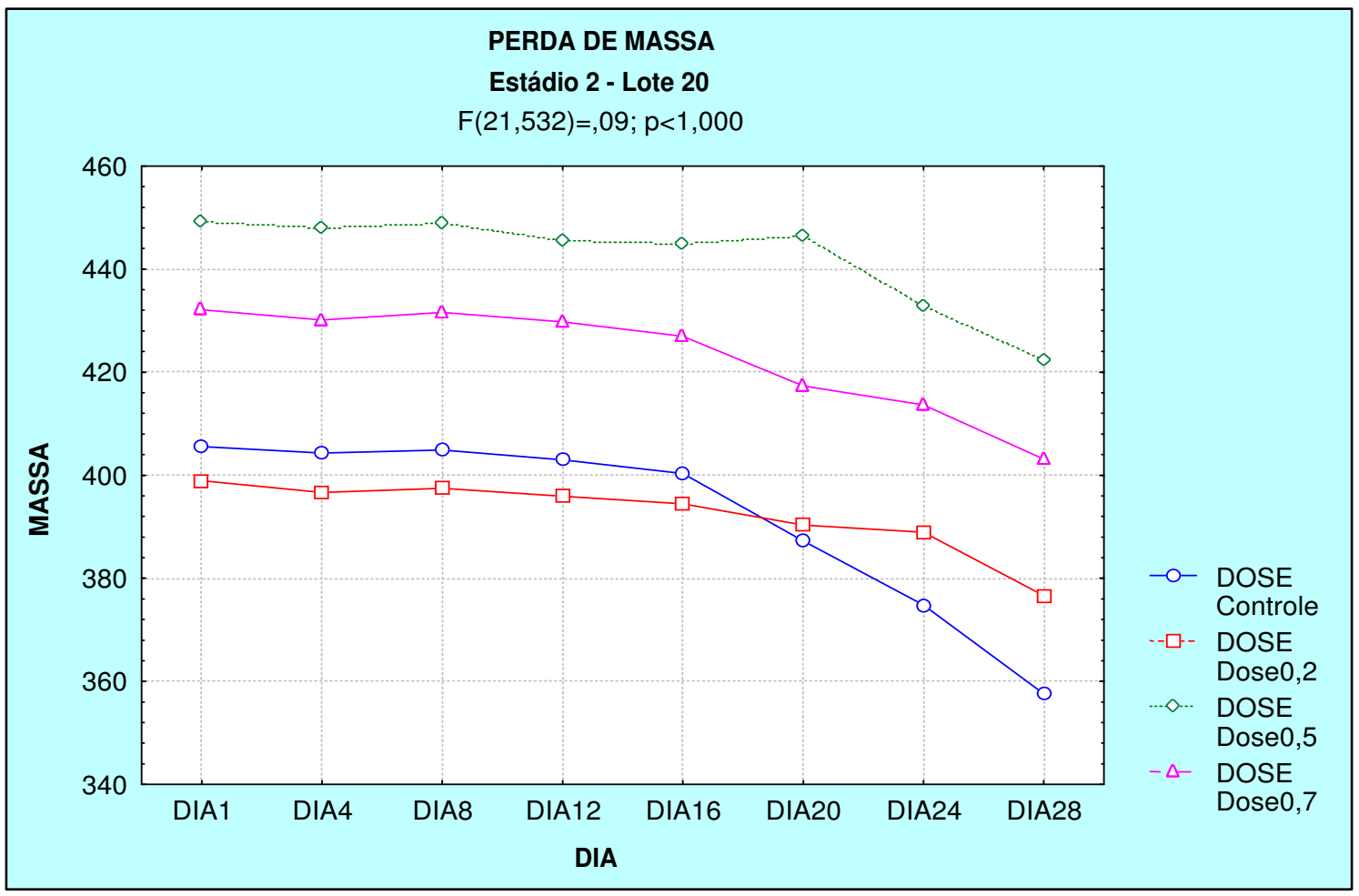

Gráfico 16 - Dias X Doses - Perda de Massa Lote 20 - Estádio 3

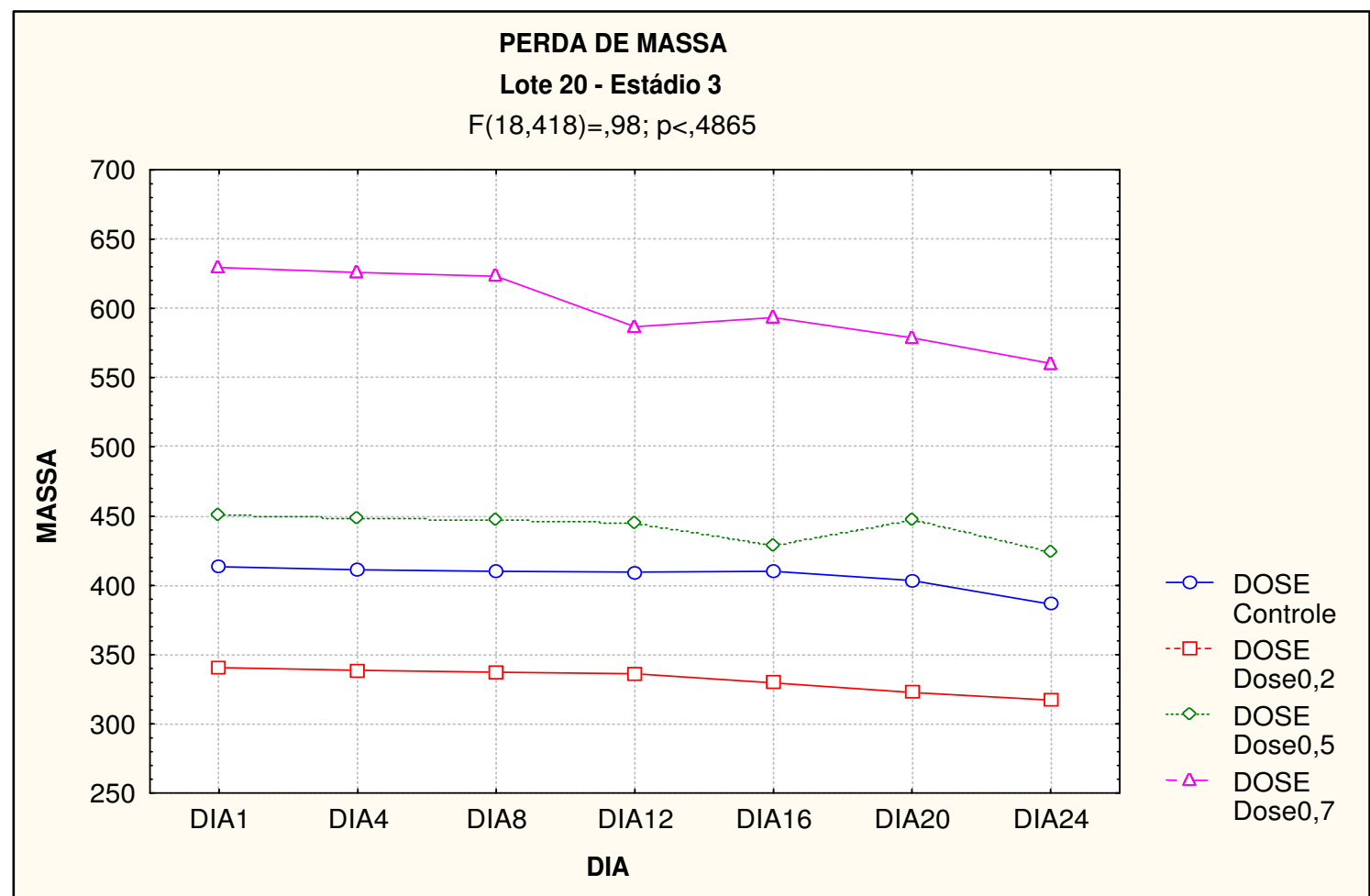




\subsection{Decomposição}

- Estádio 2

A partir da Tabela 20, observa-se que a média das mangas descartadas no Estádio 2 variou pouco entre as doses e o controle, ou seja, em todas as faixas os valores foram mantidos entre 2,00 a 2,75.

Analisando a Gráfico 17, entende-se que a decomposição dos frutos deuse de forma constante e com pouca interferência do tratamento por irradiação.

\section{- Estádio 3}

Diferente do estádio 2, as mangas no estádio 3 apresentaram diferenças nas médias de frutas descartadas por decomposição. Conforme o Tabela 21, a decomposição foi menor para os frutos tratados a $0,5 \mathrm{kGy}$, em que a média é igual a 2,00 unidades, comparada com 4,86 unidades descartadas do controle, 3,86 da dose 0,2 kGy e 5,57 mangas da 0,75 kGy.

Numa melhor visualização, o gráfico abaixo (Gráfico 18 ) revela que a seqüência decrescente de descarte por decomposição foi maior para a dose 0,75 kGy, seguida do controle, 0,2 kGy e menor para 0,5 kGy. 


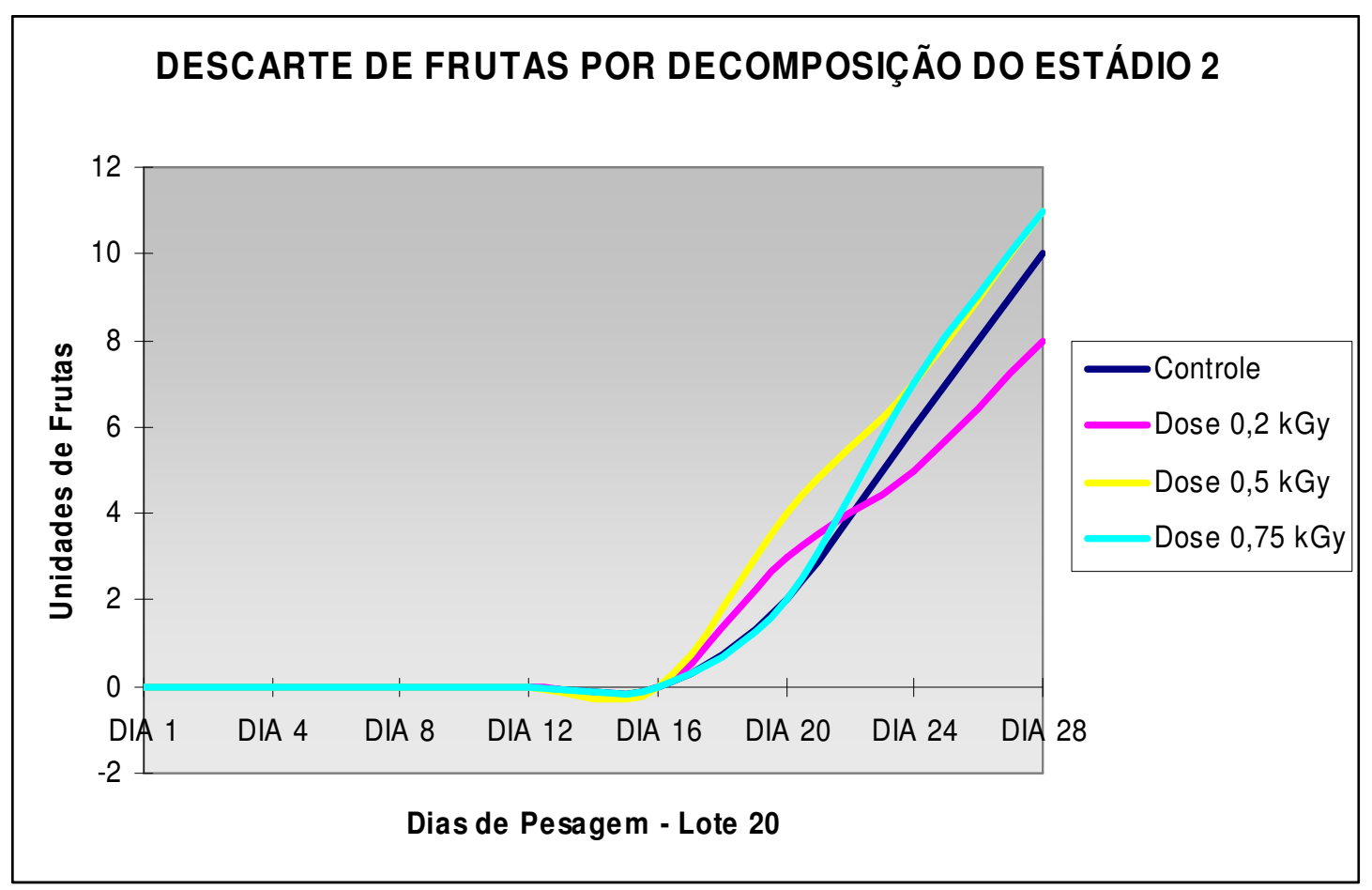

Gráfico 17 - Descarte de frutas do estádio 2

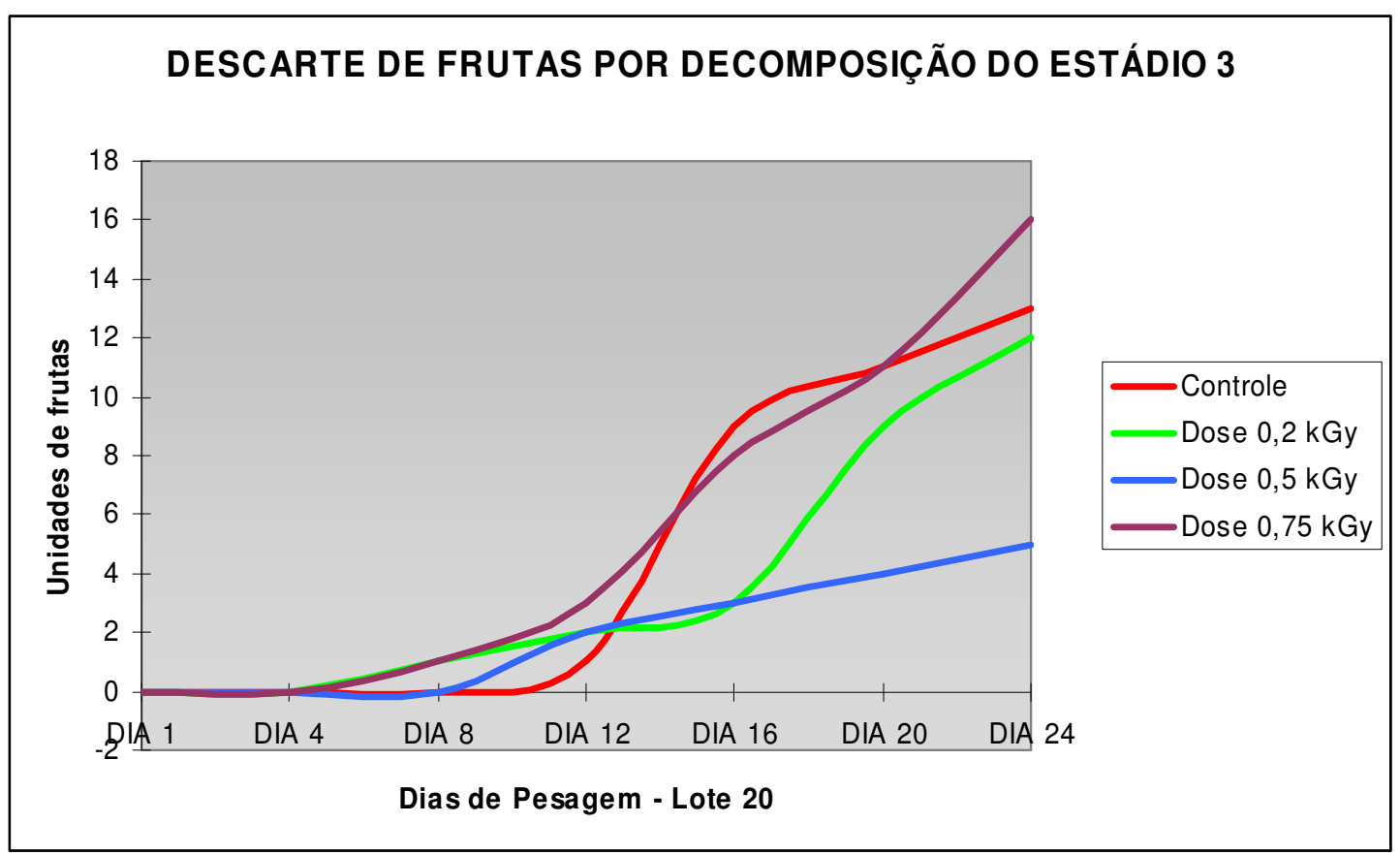

Gráfico 18 - Descarte de frutas do estádio 3 


\subsection{Análise Sensorial}

\subsubsection{Perfil dos Provadores}

A análise do perfil dos provadores do painel sensorial tem como variáveis o sexo, masculino ou feminino, a faixa etária, o grau de escolaridade, a freqüência com que consomem manga e o quando cada um conhece a respeito da irradiação de alimentos.

- Sexo

De acordo com a Figura 18, observamos que a análise sensorial foi composta por um público praticamente masculino, onde havia $71 \%$ desse para $29 \%$ de mulheres.

- Faixa etária

No total de provadores, 48\% estão na faixa etária entre 26 a 35 anos, 33\% encontram-se no intervalo de 18 a 25 anos, 17\% têm entre 36 a 45 anos e o restante, entre 46 e 55 anos, totalizam $2 \%$ (Figura 18).

\section{- Escolaridade}

Conforme a Figura 18, verifica-se que $46 \%$ dos provadores já ingressaram em Universidades, $35 \%$ já concluíram o $3^{\circ}$. grau e $19 \%$ cursaram do $1^{\circ}$. ao $2^{\circ}$. grau.

- Freqüência de consumo de manga

Entre os provadores, constatou-se que 65\% têm o hábito de consumir manga semanalmente, $4 \%$ consomem ou poderiam ingerir a fruta diariamente e praticamente $6 \%$ não se alimentam da fruta com freqüência (Figura 18). 
- Conhecimentos sobre irradiação de alimentos

Observando a Figura 18, observa-se que nenhum dos provadores considera seu conhecimento sobre irradiação de alimentos satisfatório. Assim, a quase totalidade dos provadores, $90 \%$, conhece pouco ou nunca "ouviu falar" sobre o assunto. Apenas 10\% consideraram seu entendimento razoável. 

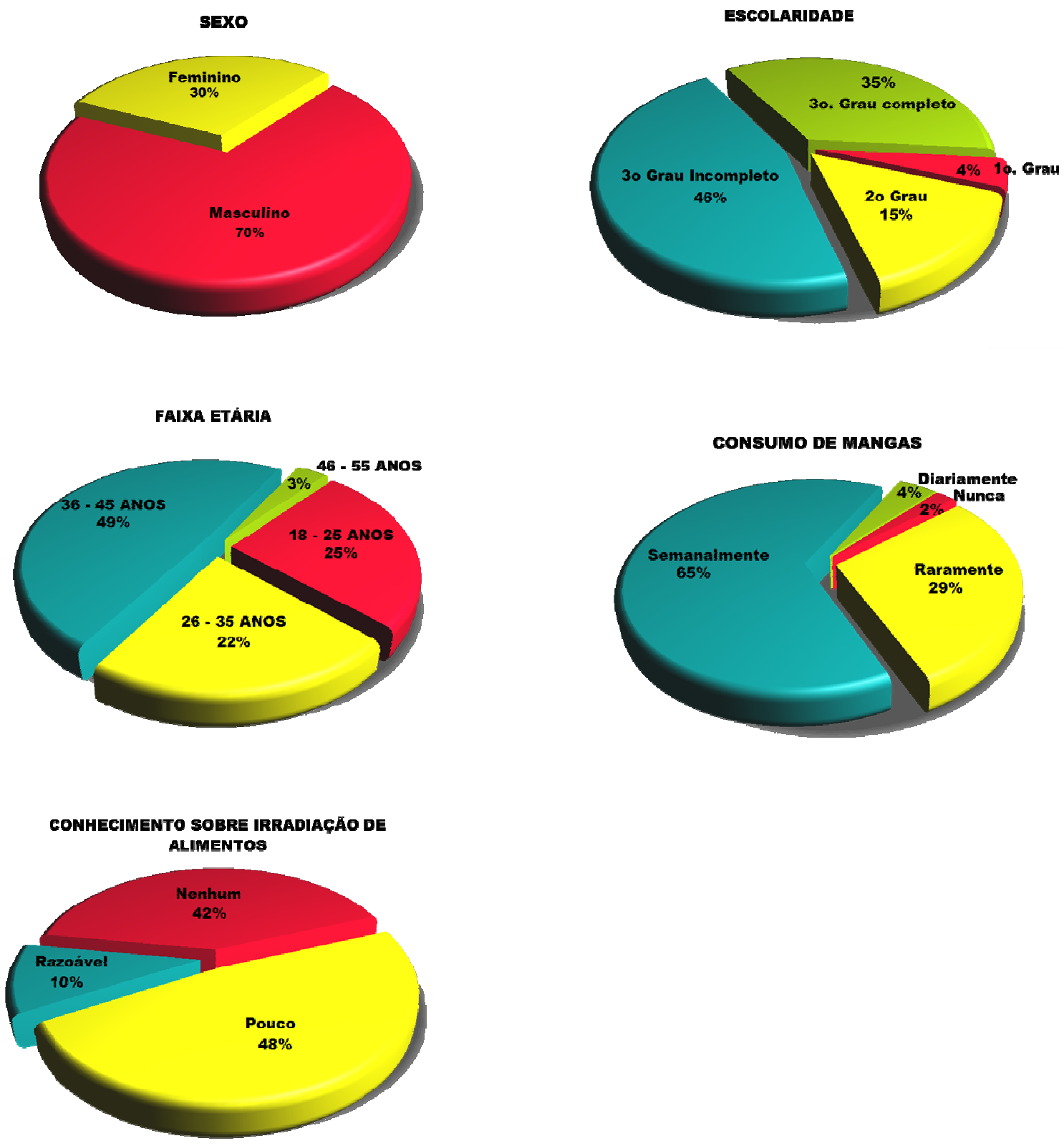

Figura 18 - Comportamento da Análise Sensorial 


\subsubsection{Análise de Dados}

Na análise estatística dos dados obtidos no Teste de Aceitação, há como atributos a cor, o odor, o sabor e a textura.

- Cor

Através dos resultados estatísticos, anexo $\mathrm{I}$, observa-se que o $\mathrm{F}_{\text {crítico é }}$ maior do que o $F\left(F_{\text {calculado }}\right)$. No ANOVA, essa ocorrência resulta na conclusão de que para o atributo cor não houve diferença significativa entre as amostras (0,5kGy, 0,75kGy e controle)

- Odor

Seguindo o conceito do atributo cor, notamos que para o odor o $F_{\text {crítico }}$ é menor do que o F. Consequentemente, dizemos que houve diferença significativa entre as amostras. Entretanto, para visualizarmos em quais delas ocorreu a diferença, aplicou-se o Teste de Tukey, conforme o anexo I. Através desse percebe-se que a diferença significativa de odor está entre o controle e a manga irradiada a 0,5 kGy.

- Sabor

Para o sabor das mangas, não ocorreu diferença significativa entre as amostras pois o $F_{\text {crítico }}>\mathrm{F}$ (Anexo $\left.\mathrm{I}\right)$.

- Textura

Conforme os resultados do anexo $\mathrm{I}$, podemos afirmar que o $\mathrm{F}_{\text {crítico }>} \mathrm{F}$. Assim, é possível afirmar que para o atributo textura não houve diferença significativa entre as amostras. 


\subsubsection{Teste de Intenção de compra}

No Teste de Intenção de Compra (Tabela 20) foi observado que $48 \%$ provavelmente comprariam mangas irradiadas, 15\% certamente comprariam, $6 \%$ não comprariam e $15 \%$ não possuem opinião sobre a intenção de compra. Como média para 0 teste obtive-se 4,0208 $\pm 0,9107$, valor correspondente ao provavelmente comprariam.

Tabela 20 - Resultados do Teste de Intenção de Compra

\begin{tabular}{c|l|c|c}
\hline Nota & \multicolumn{1}{|c|}{ Legenda } & No. Respostas & Porcentagem \\
\hline 1 & Certamente não compraria & 1 & $2 \%$ \\
\hline 2 & Provavelmente não compraria & 2 & $4 \%$ \\
\hline 3 & Talvez compra-se/ Talvez não compra-se & 7 & $15 \%$ \\
\hline 4 & Provavelmente compraria & 23 & $48 \%$ \\
\hline 5 & Certamente Compraria & 15 & $31 \%$ \\
\hline
\end{tabular}




\section{Discussão}

Em relação à análise de acidez titulável e $\mathrm{pH}$, pode-se verificar que apresentaram diferenças acentuadas no último dia em relação ao início do experimento, sendo todos os valores finais muito próximos entre si, isto é, entre as amostras irradiadas e controle. As mangas irradiadas com dose de 0,75kGy, nos dois estádios, porém de forma um pouco mais acentuada no estádio 3, apresentaram $\mathrm{pH}$ inferior, demonstrando que houve um retardo do amadurecimento nessa dose.

Em relação ao estudo da cor da casca e da cor da polpa é possível observar que a irradiação trouxe um retardo no amadurecimento das frutas uma vez que as frutas controles eram as que mais rapidamente se apresentavam no estádio 5. Porém, também foi possível notar que todas as frutas nas três doses e o controle no estádio 3 amadureceram muito mais rápidas do que as frutas no estádio 2. Em relação à comparação entre as três doses estudadas, a dose 0,75kGy foi a dose que apresentou sempre alguns frutos nos estádios 3 e 4 quando observadas nos gráficos.

A textura das mangas apresenta um decréscimo ao longo do tempo, já esperado, para os dois estádios. No estádio 3, os valores de textura foram inferiores aos valores correspondentes do estádio 2, o que também já era esperado, uma vez que as frutas no estádio 3 encontram-se mais maduras. A irradiação teve pouca influência nos valores de textura enquanto que a temperature de armazenamento foi mais preponderante (observa-se um forte decréscimo entre os dias 14 e 17 para o estádio 2).

Os valores de sólidos solúveis para o estádio 2 apresentaram um aumento inicial chegando ao máximo no dia 14 e a partir dessa data apresentaram flutuações até o final do experimento. No estádio 3, os valores dos sólidos solúveis apresentaram um decréscimo a partir do dia 1 até o final do experimento, mas com flutuações entre as médias para cada dia. A flutuação desses valores parecem mais relacionadas às flutuações dos frutos em si do que propriamente à irradiação.

A maior perda de massa dos lotes contendo 20 frutas (não destrutivo) foi observada para o controle no estádio 2 enquanto que a menor perda foi para as 
amostras irradiadas a 0,75kGy. Para o estádio 3 a menor perda de massa for para as amostras irradiadas a 0,75kGy.

No Teste de Aceitação da análise sensorial, verificou-se que o odor foi o único atributo em que houve diferença significativa entre as amostras 0,5 kGy e controle. Durante a aplicação do painel, alguns provadores observaram que a manga irradiada apresentou um odor menos característico em relação à não irradiada. No entanto, os resultados do Teste de Intenção de Compra afirmam que a maior parte dos provadores provavelmente compraria a fruta tratada por irradiação.

Assim, é possível inferir que o odor não é um atributo importante e decisivo para a compra do produto pelo consumidor. No entanto, entende-se que a aquisição da manga irradiada está ligada ao conteúdo de informação que os provadores têm sobre a irradiação de alimentos, ou seja, a maioria provavelmente compraria a manga irradiada, porém essa afirmação ainda está na região da incerteza, pois $90 \%$ dos participantes conhecem pouco ou nunca "ouviram falar" sobre a irradiação de alimentos. 


\section{Conclusões}

A partir da compilação dos resultados, conclui-se que a irradiação viabilizou a desinfestação do fruto, cumprindo a função de não alterar as propriedades da manga, e indiretamente contribuindo para o aumento da vida de prateleira.

De qualquer forma, os estudos mostram que a aplicação da irradiação na manga Tommy Atkins é significativa para manter a "saúde" da fruta durante o processo da exportação e armazenamento.

Sabe-se que exportação não é somente a arte de vender e transportar produtos de um país a outro, mas sim, é o comprometimento em enviar produtos, neste caso a manga, em condições adequadas ao consumo do mercado local. Para isto, a fruta deve encontrar-se no estádio 3 , ou seja, ainda atrativa para a compra e consumo, vindo a entrar na senescência somente no armazenamento do consumidor. A partir deste cenário, entendemos que a irradiação é uma boa aliada.

Em alguns países, como Estados Unidos e Japão, emprega-se o tratamento térmico como desinfestação do fruto, no entanto, ainda não há estudos que analisem a eficiência comercial deste método em relação à irradiação ionizante, combinados ou não.

Contudo, mesmo diagnosticada a efetividade da irradiação nos alimentos, sabe-se que o maior obstáculo para este tratamento não se encontra nos resultados, mas sim, na falta de divulgação deste processo para a sociedade.

Os resultados sensoriais deste experimento revelam que independentemente do grau de instrução, a população desconhece este tratamento. Logo, a manga sadia e boa para consumo, poderia torna-se a manga atômica, doente e cancerígena.

Assim, ciência e conhecimento popular devem caminhar juntos para que a descoberta possa sair do papel.

Sugere-se para os próximos trabalhos que sejam feitos estudos comparativos entre a efetividade da irradiação com o banho térmico, agregados ou não. Além deste, entende-se que o estudo de compostos aromáticos em mangas irradiadas pode confirmar prováveis alterações nos atributos sensoriais estudados nesta pesquisa. 


\section{Referências Bibliográficas}

ABELES, F.B. Ethylene in plant biology. Academic Press, NY, 302p., 1973.

AGÊNCIA NACIONAL DE VIGILÂNCIA SANITÁRIA (ANVISA); Resolução - RDC no 21, de 26 de janeiro de 2001. Disponível em http://www.anvisa.gov.br/legis/resol/21 01rdc.htm Acesso em 3 de dezembro de 2002.

AKINYELE, I.O.; KESHINRO, O.O. , Tropical fruits as sources of vitamin C. Food Chemistry, London, 5: 163-7, 1980.

ALVES, J.M.; BURNQUIST, H. L.; Competitividade e Tendência da Produção de Manga para Exportação do Nordeste do Brasil, Piracicaba, São Paulo, 18 20p., 2002.

AMORIM, H.V. Respiração. In: FERRI, M.G. Fisiologia Vegetal. São Paulo: EPU, 1985. Cap.6, p.251-279.

AOAC - ASSOCIATION OF OFFICIAL ANALYTICAL CHEMISTS. Official Methods of Analysis of AOAC International, $16^{\mathrm{a}}$ ed. Arlington, 2v. 1995.

ARAGÓN, N.C.; MOLINA, E.B.; ANIMAS, D.C.; ALVAREZ,D.M.; BARQUET,G.S. Almacenamiento de frutas e hortalizas. Sistema nacional para el Abasto. Secretaria de Educación Publica. Comision Nacional de Fruticultura. Secretaria de Comercio y Fomento Industrial, Mexico, 106p., 1984.

AUSTRIA, International Consultative Group on Food Irradiation (ICGFI) (Org.). Training manual on operation of food irradiation facilities. Vienna: Secretariat of ICGFI, 1992. (ICGFI document n¹4)

BENDER, R.J.; BRECHT, J., Respiração e produção de etanol e de etileno em mangas armazenadas sob diferentes concentrações de dióxido de carbono e oxigênio, Pesq. Agropec. Bras., Brasília, v.35, n.5, p. 865-871, 2000.

BENDER, R.J.; BRECHT, J.K.; CAMPBELL, C.A. Responses of "Kent"and Tommy Atkins mangoes to reduced $\mathrm{O} 2$ and elevated $\mathrm{CO} 2$. Procedures of the Florida State Horticultural Society, v.107, p.274-277, 1994.

BIALE, J.B. The postharvest biochemestry of tropical and subtropiocal fruits. Advances in Food Research, New York, Jan., 10:293-354, 1960. 
BILES, C.L.; WALL, M.M.; BLACKSTONE, K. Morphological and physiological changes during maturation of New Mexico type peppers. J. Amer. Soc. Hort. Sci, v.118, p.476-480, 1993.

BLEINROTH, E.W.; Determinações do ponto de colheita. In: MANGA PARA EXPORTAÇÃO: PROCEDIMENTOS DE COLHEITA E PÓS-COLHEITA. Brasília: EMBRAPA-SPI, 1994, p.11-28.

BRANDÃO, M.C.C.; MAIA, G.A.; LIMA, D.P.; PARENTE, E.J.S.; CAMPELLO, C.C.; NASSU, R.T.; FEITOSA, T.; SOUSA, P.H.M., Análise físico-química, microbiológica e sensorial de frutos de manga submetidos a desidratação osmótica-solar, Revista Brasileira de Fruticultura, v.25, n.1, Jaboticabal, 2003.

BRUNINI, M.A.; DURIGAN, J.F.; OLIVEIRA, A. L.; Avaliação das alterações em polpa de manga Tommy-Atkins congeladas. Revista Brasileira de Fruticultura, v.24,n.3, Jaboticabal, 2002.

BUSTOS, M. E.; ENKERLIN, W.; REYES, J.; TOLEDO, J.; Irradiation of mangoes as a postharvest quarantine treatment for fruit flies, Journal of Economic Entomology, 2004, 286-292p.

BUSTOS, M. E.; TOLEDO, W. E. J.; CASIMIRO, J. R. A.; Irradiation of mangoes as a quarantine treatment, Use of Irradiation as a Quarantine Treatment Of Food and Agricultural Commodities, Malaysia, 1990, p. 91-92.

BYRNE, M., Irradiation Update. Food Engineering International, v.21, $\mathrm{n}^{\circ} 6, \mathrm{p} .37-$ $41,1996$.

CAMARGO, R. J. Estudo do tratamento combinado de radiação ionizante e cobertura de quitosana em mamão papaia (Carica papaya L.). 2004. Tese (Mestrado) - Instituto de Pesquisas Energéticas e Nucleares, São Paulo.

CHITARRA, M.I.F.; CHITARRA, A.B. Pós-Colheita de frutos e hortaliças: fisiologia e manuseio. Lavras: ESAL, Fundação de Apoio ao Ensino, Pesquisa e Extensão, 1990.293p.

COELHO, A.H.R. Qualidade pós-colheita de pêssegos, Informe Agropecuário, v.17,n.180,p.31-38, 1994.

COMPANHIA DE DESENVOLVIMENTO DO VALE DO SÃO FRANCISCO (CODEVASF), $\quad$ http://www.codevasf.gov.br/menu/os vales/imagens/mapa1, acessado em 11 de maio de 2005. 
CRUCEFIX, D. Respiration. Syllabus of the Post-harvest Fruit, Vegetable \& Root Crop Technology Course. Tropical Development Research Institute, London, 10p., 1986.

DEL MASTRO, N.L., Development of Food Irradiation in Brazil. Progress in Nuclear Energy, v. 35, n³-4, p. 229-248,1999.

DUTCOSKY, S.D.; Análise Sensorial de Alimentos. Curitiba, PR, Editora Champagnat, 1996.

Estudo Nacional da Defesa Familiar: Tabela de Composição de Alimentos. Rio de Janeiro, Fundação Instituto Brasileiro de Geografia e Estatística - ENDEF, 1977.

FILGUEIRAS, H.A.C. Colheita e manuseio pós-colheita. In: FILGUEIRAS, H.A.C. et al. Frutas do Brasil: manga. Pós-colheita. Fortaleza: Embrapa Agroindústria Tropical. 2000. p.22-25.

FOLLETT, P.A., Mango response to mango seed weevil infestation, The ESA 2001 Annual Meeting - 2001: An Entomological Odyssey of ESA. Pacific Basin Agricultural Research Center, 2001.

FOOD AND AGRICULTURE ORGANIZATION OF THE UNITED NATIONS (FAO), http://faostat.fao.org/faostat/collections?subset=agriculture, acessado em 10 de maio de 2005.

FRANCO \& LANDGRAF, B.D.G.M.; LANDGRAF,M. Microbiologia de alimentos; São Paulo; Editora Atheneu, 1996.

GAGNON, M.; LACROIX, M.; PRINGSULAKA, V.; JOBIN, M.; LATREILLE, B.; NOUCHPRAMOOL, K.; PRACHASITTHISAK, Y.; CHARON, S.; ADULYATHAM, P.; LETTRE, J. GRAD, B.; Effect of gamma irradiation with hot water dip and transportation from Thailand to Canada on biochemical and physical chacaracteristics oh thai mangoes, Canadian Irradiation Center, Canada, 1993.

GOLDING, J.B.; SHEARER, D.; McGLASSON, W.B.; WYLLIE, S.G. Relationships between respiration, ethylene, and aroma production in ripening banana. J. Agric. Food Chem, v.47, p.1646-1651, Mar.1999.

GUARINONI, A. Efecto del estado de madurez de los frutos a la cosecha sobre su conservación. In: CONGRESSO IBEROAMERICANO DE TECNOLOGÍA Y AGROEXPORTACIONES, 2., 2000, Bogotá, Colombia. Simposio: Control de fisiopatias en frutas durante el almacenamiento en frío, Universidad Nacional de Colombia, 2000, v.1 p.29-38.

HALLMAN, G.J., lonizing radiation quarantine treatments against tephritid fruit flies. Postharvest Biology and Technology, v.16, p. 93-106, 1999. 
HARDENBURG, R.E. Effect of in-package environmet on keeping quality of fruits and vegetables. HortScience, Maryland, v.6, n.3, p.198-201, June, 1971.

IEMMA, J.; ALCARDE, A.R.; DOMARCO, R.E.; SPOTO, M.H.F.; BLUMER, L.; MATRAIA, C., Radiação gama na conservação do suco natural de laranja, Sci. agric. v.56 n.4 supl. Piracicaba 1999

KADER, A.A. Modified atmospheres during transport and storage. In: KADER, a $\underline{a}$ (ed) Postharvest technology of horticultural crops. California: University of California, 1992. P.85-92.

KADER, A.A.; Respiration. Syllabus of the Postharvest Physiology and Handling of Horticultural Commodities Course. University of California, Davis, CA, U.S. ${ }^{a}$, 19p., 1979.

KADER, A.A.; ZAGORY, D.; KERBEL, E.L. Modified atmosphere packaging of fruits and vegetable. Critical Reviews in Food Science and Nutrition, v.28, n.1, p.1-30, 1989.

KARDER, A.A. Potencial Applications of Ionizing Radiation in Postharvest Handling of Fresh Fruits and Vegetables. Food Technology, p. 117-121, 1986.

KARIM, M. N. A.; VIJAYSEGARAN, S.; YON, R. M.; LAM, P. F.; RAMLI, H.; YUSOF, N.; Gamma irradiation as a quarantine treatment for carambola, papaya and mango, Use of Irradiation as a Quarantine Treatment Of Food and Agricultural Commodities, Malaysia, 1990, p. 53-54.

LACERDA , A., Depois de 30 anos, manga brasileira entra no Japão. O Estado de São Paulo, São Paulo, 10 jan. 2005, Folha Economia, p. B4.

LACROIX, M.; GAGNON, M.; PRINGSULAKA, V.; JOBIN, M.; LATREILLE, B.; NOUCHPRAMOOL, K.; PRACHASITTHISAK, Y.; CHARON, S.; ADULYATHAM, P.; LETTRE, J. GRAD, B.; Effect of gamma irradiation with or without hot water dip and transportation from Thailand to Canada on nutritional qualities, ripening index and sensorial characteristics of thai mangoes, Canadian Irradiation Center, Canada, 1993.

LAWLESS, P.F.; HEYMANN, H.; Sensory Evaluation of Food - Principles and Practices. Aspen Publishers, Inc. 827p. 1999.

LYNCH, S.J., Avocado and mango. In: FRUIT NUTRITION. p. 79-120, New Brunswick: N.F. Childers, 1954, 906 p. 
MALAVASI, A. Problemas fitossanitários envolvidos na exportação de mangas. In: SIMPÓSIO SOBRE MANGUICULTURA, Jaboticabal, Anais... UNESP-FACAV, 1989. p. $185-190$

MANICA, I.; ICUMA I. M.; MALAVOLTA, E.; RAMOS, V. H. V.; OLIVEIRA. M. E.; CUNHA, M. M.; JUNQUEIRA, N. T. V.; Tecnologia, produção, agroindústria e exportação da manga, Ed. Cinco Continentes, Porto Alegre-RS, 2001, p. 1687:438-444.

McKENZIE, C.B. Preliminary results of calcium and potassium uptake from foliar sprays on Sensation mango. Yearbook South African Mango Growers' Association, n.14, p.24-25, 1994.

McKENZIE, C.B. The effect of calcium and potassium foliar and fruit sprays on Sensation mango leaf nutrient concentration and fruit quality. Yearbook South African Mango Growers' Association, n.15, p.24-25, 1995.

MEDLICOTT, A.P., SEMPLE, A.J., THOMPSON, A.J., BLACKBOURNE, H.R., THOMPSON, A.K., Measurement of colour changes in ripening bananas and mangoes by instrumental, chemical and visual assessments. Trop. Agric. (Trinidad). V.69, $\mathrm{n}^{\circ} 2,1992$.

MEDLICOTT, A.P. Fruit ripening. Syllabus of the Post-harvest Fruit, Vegetabe \& Root Crop. Technology Course. Tropical Development \& Research Institute, London, $7 p ., 1986$.

MEILGAARD, M.; CIVILLE, G.V.;CARR, B.T. Sensory Evaluation Techniques. Boca Raton - FL, CRC Press, Inc. 281p. 1987.

MINISTÉRIO DA AGRICULTURA E DO ABASTECIMENTO, Instrução Normativa $\mathrm{n}^{\circ} 1$, de 7 de janeiro de 2000. http://oc4j.agricultura.gov.br/agrolegis. Acessado em 13/06/2005.

MINISTÉRIO DA AGRICULTURA E DO ABASTECIMENTO, Instrução Normativa Conjunta, $\mathrm{n}^{\circ} 9$, de 12 de novembro de 2002. http://www.agricultura.org.br, Acessado em 14/05/2005.

MITCHELL, F.G.; GUILLOU, R.; PARSONS, R.A. Commercial Cooling of Fruits and Vegetables. California Agricultural Experiment Station. University of California, Davis, CA, U.S. a, Manual, n.43, 44p., 1972.

MORAIS, P.L.D.; FILGUEIRAS, H.A.C.; PINHO, J.L.N.; ALVES, R.E. Ponto de colheita ideal de mangas 'Tommy Atkins' destinadas ao mercado europeu, Revista Brasileira de Fruticultura, vol. 24, n³, Jaboticabal, São Paulo, 2002. 
MORETTI, C.L.; ARAÚJO, A.L.; SILVA, W.L.C. Alteração no metabolismo respiratório de pimentões em função do processamento mínimo e da temperatura de armazenamento. Revista da Sociedade de Olericultura do Brasil, v.18, p.331, 2000. Suplemento. /Apresentado ao 33. Congresso Brasileiro de Olericultura, São Pedro, 2000 - Resumo/.

MOY, J.H. Radurization and radicidation: fruits and vegetables. In: JOSEPHSON, E. S.; PETERSON, M.S. (Eds). Preservation of food by ionizing radiation. CRC Press, Boca Raton, v.3, cap.3, p. 83-108, 1983.

O ESTADO DE SÃO PAULO, caderno Economia. Comércio Exterior: 5 mil tons de mangas para o Japão. Quarta-feira 06/Outubro, 2004.

OLIVEIRA, M.A.; CEREDA, M.P. Utilização de película de fécula de mandioca como alternativa à cera comercial na conservação pós-colheita de frutos de goiaba (Psidium guajava). In: CONGRESSO LATINO AMERICANO DE RAÍZES TROPICAIS, 1.; CONGRESSO BRASILEIRO DE MANDIOCA, 9., São Pedro, 1996. Resumos. São Pedro, 1996.p.76.

PANTATISCO, E.B. Postharvest Physiology, Handling and Utilization of Tropical and Subtropical Fruits and Vegetables. The AVI Publ. Co., Westport, CT, 560p., 1975.

PEARSON, E.S.; HARTLEY, H.O., Biometrika Tables for Statisticians, Cambridge Un. Press, 1936.

PINTO, A. C. Q.; RAMOS, V. H. V.; JUNQUEIRA, N. T. V.; LOBATO, E.; SOUZA, D. M. G. Relação $\mathrm{Ca} / \mathrm{N}$ nas folhas e seu efeito na produção e qualidade da manga Tommy Atkins sob condições de cerrado. In: CONGRESSO BRASILEIRO DE FRUTICULTURA, 13., 1994, Salvador, Resumos... v. 2, p.763.

PINTO, A.C.Q., A produção, o consumo e a qualidade da manga no Brasil, Rev. Bras. Frutic. v.24 n.3 Jaboticabal dez. 2002.

RAM, S.; BIST. L.D.; SIROHI. S.C.. Internal fruit necrosis of mango and its control, Acta Hart. 231 :805-813p., 1989.

ROZANE, D.E.; DAREZZO, R.J.; AGUIAR, R.L.; AGUILERA, G.H.A.; ZAMBOLIM, L. Manga - Produção Integrada, Industrialização e Comercialização, Viçosa, Minas Gerais, 200 - 205p., 2004.

SILVA, A.P.F.B.; LAJOLO, F.M. ; CORDENUNSI, B.R. ; Evolução dos teores de amido e açúcares solúveis durante o desenvolvimento e amadurecimento de diferentes cultivares de manga, Ciência e Tecnologia de Alimentos, v. 23, São Paulo, FCF-USP, 2003. 
SILVA, A.V.C.; MENEZES, J.B. Caracterização físico-química da manga 'Tommy Atkins' submetida a aplicação de cloreto cálcio pré-colheita e armazenamento refrigerado, Scientia Agricola, Piracicaba, ESALQ, 2001, v.58 n.1.

SILVA, O.F.; ROCHA, E.S.; CÔRTES, M.V.C.B.; FREIRE, M.; BITTENCURT, A.M.; PIRES, L.F.G.; VITAL, H.C., Radiação Gama no Controle In Vivo e In Vitro de Colleotrichum gloesporioides Penz. e Botryodiplodia theobromae em frutos de Manga cv. "Tommy Atkings". Embrapa, Rio de Janeiro, 2006.

TEIXEIRA, M. G.; VIVIANI, L.; MARQUES, L. A.; ROSÁRIO, M.F.; FELDMAN, R.V.; PINTO, T. L.F.; Trabalho apresentado no $2^{\circ}$ DIA DA MANGA, Monte Alto, São Paulo, 2001.

THOMAS,P. Radiation preservation of foods of plant origin. III. Tropical fruits: bananas, mangoes, and papayas. In: CRC Critical Reviews is Food Science and Nutrition, Boca Raton, v.23, n.2, p.147-205, 1986.

TILTON, E.W., BURDITT, A.K. Insect Disinfestation of grain and fruit. In: JOSEPHSON, E. S.; PETERSON, M.S. (Eds). Preservation of food by ionizing radiation. CRC Press, Boca Raton, v.3, cap.7, p. 215-229, 1983.

WAINRIGHT, H.; BURBAGE, M.B. Physiological disorder in mango (Mangifera indica L.) fruit. Journal of Horticultural Science, v.42, n.2, p.125-136, 1989.

WILLS R.B.H.; PATTERSON B.C.; LEE, T.H.; GRAHAM, D.; MCGLASSON, W.B.; HALL, E.G. Postharvest. An introduction to the physiology and handling of fruit and vegetables. Kensington, New South Wales Univ. Press, 1982, 161p.

YOUNG, T. W.; MINER, J. T. Relationship of nitrogen and calcium to "soft-nose" disorder in mango fruits. Proceedings of the American Society for Horticultural Science, Alexandria, v. 78, p. 201-208, 1961.

YOUNG, T.W.;R.C.J. KOO; Effects of magnesium nitrate sprays on magnesium deficient lime trees on calcareous soil. Proceedings of the Florida State Horticultural Society.v.85 p.334-337, 1972.

YUEN, C.M.C.; TAN,S.C.; JOYCE, D. et al. Effect of postharvest calcium and polymeric films on ripening and peel injury in Kensigton Pride mango. ASEAN Food Journal, Kuala Lampur, v.8, n.3, p. 110-113, 1993. 


\section{ANEXO I}

- Cor

\begin{tabular}{|c|c|c|c|c|c|c|}
\hline $\begin{array}{l}\text { Fonte da } \\
\text { variação }\end{array}$ & $S Q$ & $g l$ & $M Q$ & $F$ & valor- $P$ & F crítico \\
\hline Linhas & 158,7731 & 47 & 3,37815 & 1,085518 & 0,361986 & 1,494975 \\
\hline Colunas & 8,883889 & 2 & 4,441944 & 1,427353 & 0,245095 & 3,093266 \\
\hline Erro & 292,5294 & 94 & 3,112015 & & & \\
\hline Total & 460,1864 & 143 & & & & \\
\hline
\end{tabular}

- Odor

\begin{tabular}{|c|c|c|c|c|c|c|}
\hline Fonte da variação & $S Q$ & $g l$ & $M Q$ & $F$ & valor- $P$ & F crítico \\
\hline Linhas & 139,4997 & 47 & 2,968079 & 1,2685 & 0,164158 & 1,494975 \\
\hline Colunas & 19,81556 & 2 & 9,907778 & 4,234393 & 0,017346 & 3,093266 \\
\hline Erro & 219,9444 & 94 & 2,339835 & & & \\
\hline Total & 379,2597 & 143 & & & & \\
\hline
\end{tabular}

grau de liberdade resíduo $=\mathrm{gl}$ amostraX gl provador

GL res =

$q(2,94)=$

MDS=

SQM RES=
94

(VALOR OBTIDO POR INTERPOLAÇÃO DA TABELA DE 3,11 PEARSON \& HARTLEY, 1936)

\begin{tabular}{ccc}
\hline & TABELA DIFERENÇAS (Teste de Tukey) \\
\hline A-B & 0,9 & (MAIOR MDS -DIFEREM) \\
A-C & 0,5 & (MENOR QUE MDS-NÃO DIFEREM) \\
B-C & 0,4 & (MENOR QUE MDS-NÃO DIFEREM) \\
\hline
\end{tabular}

Onde:
$A=$ Controle
$B=$ Dose 0,5 kGy
$\mathrm{C}=$ Dose 0,75 kGy 
- Sabor

\begin{tabular}{|c|c|c|c|c|c|c|}
\hline Fonte da variação & $S Q$ & $g l$ & $M Q$ & $F$ & valor- $P$ & F crítico \\
\hline Linhas & 114,1264 & 47 & 2,428221 & 1,107043 & 0,333111 & 1,494975 \\
\hline Colunas & 3,670972 & 2 & 1,835486 & 0,836811 & 0,43629 & 3,093266 \\
\hline Erro & 206,1824 & 94 & 2,193429 & & & \\
\hline Total & 323,9797 & 143 & & & & \\
\hline
\end{tabular}

- Textura

ANOVA

\begin{tabular}{|c|c|c|c|c|c|c|}
\hline $\begin{array}{l}\text { Fonte da } \\
\text { variação }\end{array}$ & $S Q$ & $g l$ & $M Q$ & $F$ & valor- $P$ & F crítico \\
\hline Linhas & 139,2416 & 47 & 2,962587 & 1,406665 & 0,081273 & 1,494975 \\
\hline Colunas & 9,259306 & 2 & 4,629653 & 2,198204 & 0,116677 & 3,093266 \\
\hline Erro & 197,974 & 94 & 2,106107 & & & \\
\hline Total & 346,4749 & 143 & & & & \\
\hline
\end{tabular}

